\title{
Articles
}

\section{Do Human Rights Treaties Make a Difference?}

\author{
Oona A. Hathaway ${ }^{\dagger}$
}

\section{CONTENTS}

\section{EXISTING LITERATURE ON TREATY COMPLIANCE} AND EFFECTIVENESS

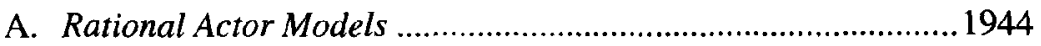

1. Realism: Compliance as Coincidence ..................................1944

2. Institutionalism: Compliance as Strategy............................. 1947

3. Liberalism: Compliance as By-Product of Domestic Politics

B. Normative Models

1. The Managerial Model: Compliance Is Due to a Norm of Compliance and Fostered by Persuasive Discourse.

$\dagger$ Associate Professor, Boston University School of Law. Associate Professor Designate, Yale Law School. J.D., Yale Law School. I thank the Carr Center for Human Rights Policy and the Center for Ethics and the Professions, both of Harvard University, for their support of this project and participants in workshops at both centers for their comments on an early draft of this Article. I thank Casey Caldwell, Teomara Hahn, Neil Austin, Seyoon Oh, Atif Khawaja, Steve Morrison, Matthew Eckert, and Jaehong Choi for their research assistance and Katherine Tragos for her data entry and research assistance. I owe a debt to Victor Aguirregabiria for consulting with me on the statistical portions of this Article, and Yulia Radionova, Martino De Stephano, and especially Firat Inceoglu for their research assistance with the statistical portions of this Article. I am also indebted to the library staff at Boston University School of Law for providing extraordinary support for and assistance with this project. Finally, I am grateful to participants in the Boston University Faculty Workshop, Karen J. Alter, lan Ayres, Lawrence Broz, Douglass W. Cassel, Jr., Daniel Farber, Ward Farnsworth, Andrew Guzman, Philip Hamburger, Jim Hathaway, Robert Howse, Robert Keohane, Alvin Klevorick, Harold Hongju Koh, Kristin Madison, Christopher McCrudden, Andrew Moravcsik, Benjamin I. Page, A.W. Brian Simpson, Mark West, and especially Jacob S. Hacker for their thoughtful comments on earlier drafts of this Article. 
2. The Fairness Model: Compliance Occurs when Rules Are Legitimate and Just.... 1958

3. The Transnational Legal Process Model: Compliance Occurs Because Norms Are Internalized.

II. TESTING COMPLIANCE

A. The Challenges of Measuring Compliance and Effectiveness ... 1963

1. Genocide 1968

2. Torture 1969

3. Fair Trial. 1972

4. Civil Liberty 1975

5. Women's Political Equality

B. Do Countries Comply? 1976

C. Are Treaties Effective? 1989

III. THE DuAl Roles of Human Rights TREATIES .2002

IV. LOOKING AHEAD: CAN TREATIES MAKE A DIFFERENCE? .2020

APPENDIX A: LIST OF TREATIES 2026

APPENDIX B: DATA SOURCES, DEFINITIONS, AND EXPLANATIONS FOR THE INDEPENDENT VARIABLES 2027

APPENDIX C: CODED DATA AND COMPLETE STATISTICAL RESULTS.....2034 
International lawyers for the most part assume that, as Louis Henkin memorably put it, "almost all nations observe almost all principles of international law and almost all of their obligations almost all of the time." 1 This assumption undergirds the work of many legal scholars and practitioners, who endeavor to explicate and form the law presumably because they believe that it has real impact. Indeed, the claim that international law matters was until recently so widely accepted among international lawyers that there have been relatively few efforts to examine its accuracy. ${ }^{2}$ Yet this view long coexisted with a much more skeptical conception of international law among international relations scholars-a conception that holds that, in the immortal words of Thucydides, "[t]he

1. LOUIS HENKIN, How NATIONS BEHAVE 47 (2d ed. 1979) (emphasis omitted); see ABRAM Chayes \& antonia Hander Chayes, THE NEW SOVEREIGNTY: COMPliance WITH INTERNATIONAL REGULATORY AGREEMENTS 3 (1995) (" [F]oreign policy practitioners operate on the assumption of a general propensity of states to comply with international obligations."); ANDREW T. GUZMAN, INTERNATIONAL LaW: A COMPLIANCE BASED ThEORY (Univ. of Cal. at Berkeley Sch. of Law, Public Law and Legal Theory Working Paper No. 47, 2001); Abram Chayes \& Antonia Handler Chayes, On Compliance, 47 INT'L ORG. 175, 176 (1993); Harold Hongju Koh, Why Do Nations Obey International Law?, 106 YALE L.J. 2599, 2599 (1997) (book review). But see Francis A. Boyle, The Irrelevance of International Law: The Schism Between International Law and International Politics, 10 CAL. W. INT'L L.J. 193 (1980) (arguing against the importance of international law); Robert H. Bork, The Limits of "International Law," NAT"L INT., Winter 1989-1990, at 3 (same).

2. See Benedict Kingsbury, The Concept of Compliance as a Function of Competing Conceptions of International Law, 19 MICH. J. INT’L L. 345, 346 (1998) (“[T]he first empirical task is to determine whether, as is often asserted by international lawyers, most States and other subjects of international law conform to most legal rules most of the time. We have impressions which may rise to the level of "anecdata," but in many areas we simply do not have systematic studies to show whether or not most States conform to most international law rules most of the time...." (citations omitted)); Koh, supra note 1, at 2599-600 ("[S]cholars have generally avoided the causal question: If transnational actors do generally obey international law, why do they obey it, and why do they sometimes disobey it?"); S.M. Schwebel, Commentary, in COMPLIANCE WITH JUDGMENTS OF INTERNATIONAL COURTS 39, 39 (M.K. Bulterman \& M. Kuijer eds., 1996) ("Compliance is a problem which lawyers tend to avoid rather than confront."). There are some notable exceptions. E.g., Douglass Cassel, Does International Human Rights Law Make a Difference?, 2 CHI. J. INT'L L. 121 (2001) [hereinafter Cassel, Does International Human Rights Law Make a Difference?]; Douglass Cassel, Inter-American Human Rights Law, Soft and Hard, in COMMITMENT AND COMPLIANCE: THE ROLE OF NON-BINDING NORMS IN THE INTERNATIONAL LAW SYSTEM 393 (Dinah Shelton ed., 2000); Linda Camp Keith, The United Natians International Covenant on Civil and Political Rights: Does It Make a Difference in Human Rights Behavior?, 36 J. PEACE RES. 95 (1999); Beth A. Simmons, International Law and State Behavior: Commitment and Compliance in International Monetary Affairs, 94 AM. POL. SCI. REV. 819 (2000); Edith Brown Weiss \& Harold K. Jacobson, A Framework for Analysis, in ENGAGING COUNTRIES: STRENGTHENING COMPLIANCE WITH INTERNATIONAL ENVIRONMENTAL ACCORDS 1 (Edith Brown Weiss \& Harold K. Jacobson eds., 1998) [hereinafter ENGAGING COUNTRIES]. In recent years, legal scholars have paid more attention to the question of compliance. Indeed, the 91 st Annual Meeting of the American Society of International Law was entitled, "Implementation, Compliance and Effectiveness." AM. SOC'Y OF INT'L LAW, PROCEedings OF THE 91ST ANNUAL MEETING: IMPLEMENTATION, COMPLIANCE AND EFFECTIVENESS (1997). 
strong do what they can and the weak suffer what they must," ${ }^{3}$ with little regard for international law. ${ }^{4}$

The disinclination of international lawyers to confront the efficacy of international law is nowhere more evident-or more problematic - than in the field of human rights law. After all, the major engines of compliance that exist in other areas of international law are for the most part absent in the area of human rights. Unlike the public international law of money, there are no "competitive market forces" that press for compliance. ${ }^{5}$ And, unlike in the case of trade agreements, the costs of retaliatory noncompliance are low to nonexistent, because a nation's actions against its own citizens do not directly threaten or harm other states. Human rights law thus stands out as an area of international law in which countries have little incentive to police noncompliance with treaties or norms. As Henkin remarked, "The forces that induce compliance with other law ... do not pertain equally to the law of human rights." 6

Are human rights treaties complied with? Are they effective in changing states' behavior for the better? These are critical questions not only for our assessment of human rights treaties, but also for our understanding of the effects of international law more generally. If states act primarily in pursuit of their self-interest, as dominant theories of international relations generally assume, a finding that human rights law frequently alters state behavior would be deeply puzzling, for human rights treaties impinge on core areas of national sovereignty without promising obvious material or strategic benefits. Indeed, a finding that human rights treaties play an important constraining role would provide powerful evidence for the view, embraced by many scholars and practitioners of international law, that state action is critically shaped by the persuasive power of legitimate legal obligations. Examining the effects of human

3. ThUCYDIDES, HISTORY OF THE PELOPONNESIAN WAR 394 (R. Crowley trans., 1920).

4. See, e.g., Michael Byers, Custom, POWER, AND THE POWER OF RUles: INTERNATIONAL RELATIONS AND CUSTOMARY INTERNATIONAL LAW 8 (1999) ("International Relations scholars have traditionally had little time for [questions of international law]. Instead, they have regarded international law as something of an epiphenomenon, with rules of international law being dependent on power, subject to short-term alteration by power-applying states, and therefore of little relevance to how states actually behave." ); George W. Downs et al., Is the Good News About Compliance Good News About Cooperation?, 50 INT'L ORG. 379 (1996); Beth A. Simmons, Money and the Law: Why Comply with the Public International Law of Money?, 25 YALE J. INT'L L. 323, 323-24 (2000) (" [M] ost legal scholars and practitioners believe that the rules at the center of their analysis do indeed matter.... Scholars of international relations, ... however, have been far more skeptical.").

5. See Simmons, supra note 4, at 326 (arguing that "competitive market forces" in the form of "[t]he risk of deterring international business [are] what give[] international monetary law its constraining influence").

6. HENKIN, supra note 1 , at 235. 
rights treaties thus offers a rare opportunity to put dominant views of international law to the test. ${ }^{\text {? }}$

This Article undertakes that test with a large-scale quantitative analysis of the relationship between human rights treaties and countries' human rights practices. The analysis relies on a database encompassing the experiences of 166 nations over a nearly forty-year period in five areas of human rights law: genocide, torture, fair and public trials, civil liberties, and political representation of women. This data set is the empirical window through which I examine two separate but intimately related questions. First, do countries comply with or adhere to the requirements of the human rights treaties they have joined? Second, do these human rights treaties appear to be effective in improving countries' human rights practices-that is, are countries more likely to comply with a treaty's requirements if they have joined the treaty than would otherwise be expected?

A quantitative approach to these questions makes it possible to trace relationships between treaty ratification and country practices that would be difficult, if not impossible, to detect in qualitative case-by-case analyses. ${ }^{9}$ In an analysis of individual cases, there is virtually no way to know whether better or worse human rights practices are due to treaty ratification or instead to any number of other changes in country conditions, such as a change in regime, involvement in civil war, or a change in economic context. Designed correctly, therefore, comprehensive statistical analysis can isolate more effectively the particular effects of treaty ratification on country practices. And such an analysis can achieve a breadth of coverage that would be infeasible in a qualitative case-by-case analysis.

To be sure, the quantitative approach is not without drawbacks. Although a quantitative analysis can have a scope that is impractical in a qualitative analysis, it necessarily brushes over the nuances of historical context that can only be garnered from a case-study approach. This is, of course, an argument not for abandoning quantitative analysis but instead for supplementing it with qualitative evidence. ${ }^{10} \mathrm{~A}$ second obvious drawback of

7. One other article undertakes a similar quantitative test of the relationship between human rights practices and treaty ratification and finds results similar to those reported in this Article. Keith, supra note 2.

8. Edith Brown Weiss and Harold $K$. Jacobson provide a framework of analysis for what has traditionally been referred to simply as "compliance" that separates out notions of "implementation," "compliance," and "effectiveness." See Weiss \& Jacobson, supra note 2, at 4-6.

9. For some excellent case studies of these relationships, see, for example, ENGAGING COUNTRIES, supra note 2; THE POWER OF HUMAN RIGHTS (Thomas Risse et al. eds., 1999); and A.W. BRIAN SIMPSON, HUMAN RIGHTS AND THE END OF EMPIRE (2001).

10. Indeed, this Article is the first step in a broader project that will include a series of case studies that will test the findings of the statistical analyses and verify, strengthen, and deepen the arguments made in this Article. My earlier study of the impact of free trade agreements in the United States takes just such a case-study approach. See Oona A. Hathaway, Positive Feedback: 
statistical inquiry is that the accuracy of the analysis necessarily depends on the accuracy of the data on which it rests. To address this problem, I draw on several different data sources and cross-check all my results against more than one source. Nonetheless, to the extent that the data on which my study rests are imperfect, there remains a risk that the conclusions I draw are similarly imperfect. The questions that this Article addresses are worth considering even if the answers fall short of certainty and even if much room remains for additional quantitative and qualitative research.

From the standpoint of leading perspectives on international law, the results of my research are counterintuitive. Although the ratings of human rights practices of countries that have ratified international human rights treaties are generally better than those of countries that have not, noncompliance with treaty obligations appears to be common. More paradoxically, when I take into account the influence of a range of other factors that affect countries' practices, I find that treaty ratification is not infrequently associated with worse human rights ratings than otherwise expected. I do, however, find evidence suggesting that ratification of human rights treaties by fully democratic nations is associated with better human rights practices. These findings are not fully consistent with either the classic interest-based or the norm-based views of international law. If treaties are simply window-dressing for the self-interested pursuit of national goals, then there should be no consistent relationship between ratification and state behavior, positive or negative. If, by contrast, they have a powerful normative hold, then ratification of human rights treaties should be associated with better practices-not only by fully democratic nations-and should never be associated with worse practices.

My findings do not necessarily tell us that treaties lead to worse human rights practices. Countries with worse practices may be more inclined to ratify treaties, or we may simply know more about violations committed by countries that sign human rights treaties, making countries that ratify look worse than they are. Yet given that $I$ find not a single treaty for which ratification seems to be reliably associated with better human rights practices and several for which it appears to be associated with worse practices, it would be premature to dismiss the possibility that human rights treaties may sometimes lead to poorer human rights practices within the countries that ratify them.

This suggestion is not as outrageous as it might at first appear. The counterintuitive results may be explained at least in part, I argue, by a conception of international treaties that takes account of their dual nature as both instrumental and expressive instruments. Treaties are instrumental in

The Impact of Trade Liberalization on Industry Demands for Protection, 52 INT'L ORG. 575 (1998). 
that they create law that binds ratifying countries, with the goal of modifying nations' practices in particular ways. But treaties also declare or express to the international community the position of countries that have ratified. The position taken by countries in such instances can be sincere, but it need not be. When countries are rewarded for positions rather than effects-as they are when monitoring and enforcement of treaties are minimal and external pressure to conform to treaty norms is highgovernments can take positions that they do not honor, and benefit from doing so. "In this respect, human rights treaties lie in contrast to Article VIII of the IMF's Articles of Agreement, for which compliance information is readily available and which Beth Simmons has found to have a significant positive influence on state behavior. ${ }^{12}$

This perspective helps explain why treaty ratification might sometimes be associated with worse human rights practices than otherwise expected. Countries that take the relatively costless step of treaty ratification may thereby offset pressure for costly changes in policies. Because monitoring and enforcement are usually minimal, the expression by a country of commitment to the treaty's goals need not be consistent with the country's actual course of action.

Although ratification of human rights treaties appears to have little favorable impact on individual countries' practices, this finding does not preclude the possibility that treaties have favorable effects on human rights across the board. And human rights treaties may have positive effects on ratifying countries over the long term, creating public commitments to which human rights activists can point as they push nations to make gradual, if grudging, improvements down the road. Indeed, these dynamics are not mutually exclusive. Treaty ratification may set in play both positive and negative forces, which together often lead to little or no net effect on state practices.

This Article proceeds in four stages. Part I discusses the existing. international relations and legal literature on compliance with international law, dividing contending schools into two broad camps: rational actor

11. In this Article, I use the terms "nation," "country," and "government" interchangeably to refer to various domestic-level governing institutions through which a series of individuals take actions and make decisions. The process of national decisionmaking and the interaction between domestic and international players is of course important to a complete understanding of treaty compliance. This Article explores the role of domestic politics to a limited extent by examining the impact of the level of democratization of a country on its human rights practices and on its propensity to ratify human rights treaties, and by discussing possible explanations for countries' compliance practices. See, e.g., infra text accompanying note 246 . The role of domestic politics in treaty compliance is the subject of my ongoing research and will be addressed more fully in future work.

12. Simmons, supra note 2, at 832 (finding that "[o]nce we control for most of the obvious reasons a govemment may choose to restrict its current account, Article VIII status still emerges as a truly significant influence on the probability of choosing to restrict [the current account]"). 
models and normative theory. By developing an inclusive framework for understanding the international-relations and international-law literature on compliance, I aim to clarify the basic fault lines in the debate and further existing efforts to conceive of these two previously divided disciplines as a unified whole. Part II discusses the design of the empirical analysis and reviews the results. The analysis uses a wide range of evidence to evaluate a central question of international law: Do human rights treaties make a difference in state behavior? I begin by comparing the practices of treaty ratifiers with those of nonratifiers to show that the extent of compliance is not only lower than might be expected, but also varies within the universe of nations in revealing ways. I then turn to the crucial quantitative tests, examining the relationship between treaty ratification and country practices in the context of a range of other factors expected to influence country practices, including economic development, civil and external wars, and levels of democratization.

Part III returns to the theory in light of the evidence, pitting contending explanations against the empirical findings and developing my own argument for the paradoxical results that $I$ find. Drawing upon and amending existing theories of international law, I argue that treaties must be understood as dual instruments, in which both expressive functions and instrumental ends sometimes uneasily coexist. The results of the empirical analyses indicate that state expressions of commitment to human rights through treaty ratification may sometimes relieve pressure on states to pursue real changes in their policies and thereby undermine the instrumental aims of those very same treaties. The concluding Part IV discusses possible favorable effects of human rights treaties that may be overlooked by the quantitative analysis and considers the ways in which the expressive and instrumental roles of treaties might be better aligned to ensure that international human rights laws will more effectively lead to improvements in the lives of those they are meant to help.

\section{EXISTING LITERATURE ON TREATY COMPLIANCE AND EFFECTIVENESS}

Until fairly recently, the question of international law compliance fell by the wayside of both international law and international relations scholarship. Legal scholars examined and explicated the rules of state international behavior, generally taking as a given that the rules would have impact. International relations scholars, for their part, had little interest in international law. The centrality in international relations of realist thinking, which accepted the view that nation-states operated "in a tenuous net of 
breakable obligations," discouraged careful examination of the role of transnational institutions and hence of international law. ${ }^{13}$

At the same time, the few advances that each discipline made in examining international compliance were largely ignored by the other. Writings on international law were largely concerned with the formation, promulgation, and codification of international laws. Although scholars of international law obviously understood that these rules are not selfexecuting and that nations vary in the degree to which they adhere to them, relatively little attention was given to the broader economic and political environment that conditions the making of international law and nations' responses to it. This environment was, by contrast, the very focus of much of the international relations literature, yet international relations scholars did not explore whether and how international law fits into it. Perhaps most indicative of the mutual isolation of the two disciplines was the general failure of international law scholars to use quantitative techniques and rational choice theory, which had emerged as important tools of analysis in political economy but had generally taken a back seat to more traditional modes of legal argumentation and analysis in writing on international law. In turn, international relations scholars often ignored international law scholarship altogether.

In recent years, the chasm between the disciplines has narrowed as international law and international relations theorists have begun to share insights. ${ }^{14}$ Yet compliance with and effectiveness of international human rights law remains a dark corner into which few have bothered to peer. Here, I sketch out the primary existing theories of international law compliance and effectiveness in both international law and international relations scholarship, taking special note of the few instances where human rights law is specifically considered. In light of the growing harmony and discourse between international law and international relations scholarship,

13. Stanley Hoffmann, The Role of International Organization: Limits and Possibilities, 10 INT'L ORG. 357, 364 (1956).

14. In law, much of the attention to international relations theory began with Kenneth $W$. Abbott, Modern International Relations Theory: A Prospectus for International Lawyers, 14 YALE J. INT'L L. 335 (1989) [hereinafter Abbot, Modem International Relations Theory]. Progress since then has been slow but steady on both sides. Witness the Summer 2000 issue of International Organization, the flagship of international relations scholarship, which was devoted to intemational relations approaches to international law, and the American Journal of International Law, which has devoted several articles to charting the burgeoning interdisciplinary scholarship. See, e.g., Kenneth W. Abbott, International Relations Theory, International Law, and the Regime Governing Atrocities in Internal Conflicts, 93 AM. J. INT'L L. 361 (1999); AnneMarie Slaughter Burley, International Law and International Relations Theory: A Dual Agenda, 87 AM. J. INT'L L. 205 (1993); Anne-Marie Slaughter et al., International Law and International Relations Theory: A New Generation of Interdisciplinary Scholarship, 92 AM. J. INT'L L. 367 (1998). For further commentary, see THE ROLE OF LAW IN INTERNATIONAL POLITICS (Michael Byers ed., 2000); and the American Society of International Law's planned conference in 2002, "The Legalization of International Relations/The Internationalization of Legal Relations." 
I opt to blend the two scholarships in defining two broad approaches, which I group under the labels "rational actor models" and "normative theory." is

Before I begin a review of the literature in more detail, two caveats are in order. First, as any brief review of a rich literature must, the following discussion skims only the surface of deeply complex theories in order to draw out their implications for human rights treaty compliance. Second, by delineating the distinctions among the theories, I do not intend to suggest that they are mutually exclusive. Each approach provides useful and often complementary insights into the puzzle of treaty compliance. Indeed, the goal of this Article is not to supplant, but to supplement, these theories so that they are individually and collectively better equipped to explain treaty compliance.

\section{A. Rational Actor Models}

The theories I term "rational actor models" have at their heart a shared belief that states and the individuals that guide them are rational selfinterested actors that calculate the costs and benefits of alternative courses of action in the international realm and act accordingly. In this view, international law does not hold a privileged position. It is one of a series of tools available to the relevant actors in their ongoing battle to achieve their self-interested ends. Compliance does not occur unless it furthers the selfinterest of the parties by, for example, improving their reputation, enhancing their geopolitical power, furthering their ideological ends, avoiding conflict, or avoiding sanction by a more powerful state. The three variants of this model outlined below differ primarily in the types and sources of interests that they claim motivate country decisions.

\section{Realism: Compliance as Coincidence}

In what was once the most widely accepted theory of state action among international relations scholars (and is now of growing influence in international law), international treaties and institutions exist only because powerful states benefit from their presence. The most traditional version of this approach, labeled "classical realism," was dominant in academic and policy circles in the years following World War II. In this view, states are

15. My framing mirrors that of Robert $O$. Keohane. Robert $O$. Keohane, International Relations and International Law: Two Optics, 38 HARV. INT'L L.J. 487 (1997). For good summaries of the relationship between international relations theory and intemational legal scholarship, see Slaughter Burley, supra note 14; and Slaughter et al., supra note 14. See also Abbott, Modern International Relations Theory, supra note 14, at 337-38; John K. Setear, An Iterative Perspective on Treaties: A Synthesis of International Relations Theory and International Law, 37 HARV. INT'L L.J. 139 (1996); Beth A. Simmons, Compliance with International Agreements, 1 ANN. REV. POL. SCI. 75 (1998). 
motivated exclusively by their geopolitical interests. ${ }^{16}$ International law exists and is complied with only when it is in the interests of a hegemon or a few powerful states, which coerce less powerful states into accepting the regime and complying with it. International law is therefore in this view largely epiphenomenal. ${ }^{17}$

The strong version of this view no longer holds sway, ${ }^{18}$ in large part because its dismissal of international regimes ran into difficulty in the 1970s and 1980s when its predictions rapidly diverged from empirical reality. ${ }^{19}$ Instead, classical realism has given way in the last two decades to a more nuanced approach, termed by its proponents "neorealism" or "structural realism," that shares with classical realism a conception of states as unitary actors and a focus on the international system as the relevant level of analysis. Neorealists abandoned classical realism's exclusive focus on international power arrangements and instead use concepts drawn from game theory and economics--known under the broad rubric of rational choice theory-to understand and explain international cooperation and discord. Like classical realism, however, neorealism, as conceived of in Kenneth Waltz's foundational Theory of International Politics $^{20}$ and its progeny, leaves little room for international institutions. Rather, international politics take place in an international environment defined by anarchy and filled with states that are "unitary actors who, at a minimum, seek their own preservation and, at a maximum, drive for universal domination." ${ }^{21}$ In this view, therefore, if compliance with international law occurs, it is not because the law is effective, but merely

16. See EdWARD HalletT CARR, THE TwenTY Years' CRISIS 1919-1939 (Harper \& Row 1946) (1939); HANS J. MORGENTHAU, POLITICS AMONG NATIONS (3d ed. 1966); Keohane, supra note 15, at 489 ("The 'instrumentalist optic' focuses on interests and argues that rules and norms will matter only if they affect the calculations of interests by agents."); Hans J. Morgenthau, Positivism, Functionalism, and International Law, 34 AM. J. INT'L L. 260 (1940).

17. See HENKIN, supra note 1, at 49 (labeling as "It]he cynic's formula" the realist view that "since there is no body to enforce the law, nations will comply with international law only if it is in their interest to do so; they will disregard law or obligation if the advantages of violation outweigh the advantages of observance").

18. For critiques of classical realism, see, for example, ROBERT O. KEOHANE, AFTER HEGEMONY (1984); and Duncan Snidal, The Limits of Hegemonic Stability Theory, 39 INT'L ORG. $579(1985)$.

19. See, e.g., Jeff Frieden, Sectoral Conflict and Foreign Economic Policy, 1914-1940, 42 INT'L ORG. 59 (1988) (seeking to understand why the United States was so slow to assume a position of leadership in the interwar years despite its power position in the world); Judith Goldstein, Ideas, Institutions, and American Trade Policy, 42 INT'L ORG. 179 (1988) (finding that American trade policy remained liberal in the 1970s and 1980s despite the country's relative decline within the international economy); Michael Mastanduno, Trade as a Strategic Weapon: American and Alliance Export Control Policy in the Early Postwar Period, 42 INT'L ORG. 121 (1988) (finding that the United States was unable to maintain the trade regime it preferred in the 1950 s, even though it was at the zenith of its hegemonic power).

20. KenNETH N. WALTZ, ThEORY OF INTERNATIONAL POLITICS (1979).

21. Id. at 118 . 
because compliance is coincident with the path dictated by self-interest in a world governed by anarchy and relative state power.

Both strands of realist theory face a difficult task when called upon to explain the existence of and compliance with human rights regimes. The observation by a state of the human rights of its citizens provides little or no direct benefits to other states. It is therefore difficult for realists to explain why states would be willing to incur the costs of setting up a regime to protect human rights, surrender to that regime the power to control and monitor some aspects of their interactions with their own citizens, commit to bring themselves into line with treaty requirements, and agree to engage where necessary in sanctioning activity to bring others into compliance.

Perhaps the most widely shared view of such laws among realist scholars is that efforts to secure human rights are, in essence, "cheap talk" - an example of governments using liberal ideological arguments to justify actions that they take in pursuit of wealth and power. ${ }^{22}$ In this view, state behavior that is consistent with the requirements of human rights treaties can only be explained as mere coincidence because no state would actually change its behavior in response to a human rights treaty absent some independent motivation.

Some neorealist scholars, by contrast, accept that a state's commitment to human rights can be genuine and can indeed be no less important in explaining the motivations of countries than material interests. ${ }^{23}$ Kenneth Waltz, for instance, accepts the possibility that some countries are genuinely committed to human rights and explains human rights regimes as simply a result of powerful nations seeking to impose their commitment to human rights on other nations. ${ }^{24}$ In this view, states comply with human rights norms because they are coerced into doing so by more powerful nations. This neorealist explanation, however, is not entirely consistent with observed reality. In practice, the most powerful nations are often not among

22. See CARR, supra note 16; MORGENTHAU, supra note 16. Of course, there remains a gaping hole in the logic of this argument: If nations are really just motivated by self-interest and international relations are simply guided by the interests of the most powerful states, why do countries bother with cheap talk about human rights? Part III of this Article attempts to provide an answer.

23. Jack Donnelly, International Human Rights: A Regime Analysis, 40 INT'L ORG. 599, 616 (1986).

24. WALT7, supra note 20 , at 200 . Waltz states:

Like some earlier great powers, we [the United States] can identify the presumed duty of the rich and powerful to help others with our own beliefs about what a better world would look like. England claimed to bear the white man's burden; France spoke of her mission civilisatrice. . . . For countries at the top, this is predictable behavior.

Id. Curiously, Waltz does not explain where the powerful nations' commitment to human rights comes from or why nations would be willing to sacrifice more tangible interests and benefits in pursuit of human rights. 
those pressing for human rights treaties. ${ }^{25}$ Indeed, the United States, which has been indisputably the strongest world power since World War II, has shown some antipathy toward human rights law, having ratified as of 1999 only seven of nineteen non-International Labour Organization universal human rights treaties with binding legal effect, compared with a median of ten for the 165 other countries included in my database. ${ }^{26}$ Thus realist and neorealist approaches suggest that if state action is consistent with the requirements of international human rights law, it is most likely the result of coincidence rather than the force of the law. Consequently, they would likely predict no significant relationship between human rights treaty ratification and government behavior.

\section{Institutionalism: Compliance as Strategy}

In contrast with realist models, institutionalism takes system-wide institutions seriously. Institutionalists, including most notably Robert Keohane ${ }^{27}$ seek to explain why international institutions exist and how they influence state action. ${ }^{28}$ Like neorealism, institutionalism for the most part

25. See, e.g., Andrew Moravcsik, The Origins of Human Rights Regimes: Democratic Delegation in Postwar Europe, 54 INT'L ORG. 217, 219-20 (2000) (arguing that "[a]lthough established democracies [in Europe] supported certain human rights declarations, they allied with dictatorships and transitional regimes in opposition to reciprocally binding human rights enforcement" (emphasis omitted)).

26. Author's calculations, based on ratification information on treaties filed with the Secretary Gencral of the United Nations. See United Nations Treaty Collection, at http://untreaty.un.org/English/access.asp (last visited Apr. 2, 2002). I label as "universal human rights treaties" those treaties included in U.N. CTR. FOR HUMAN RIGHTS, HUMAN RIGHTS: A COMPILATION OF INTERNATIONAL INSTRUMENTS 419, U.N. Doc. ST/HR/I/Rev.5, U.N. Sales No. E.94.XIV.1 (1994), that are open to signature by any member of the United Nations without geographical or other restriction and that have binding legal power. See id. at xii. Several scholars have discussed the apparent aversion of the United States to human rights law. See, e.g., Cormac T. Connor, Human Rights Violations in the Information Age, 16 GEO. IMMIGR. L.J. 207, 230 (2001) ("In 1953, Secretary of State John Foster Dulles asserted that the United States did not intend to ratify any international human rights treaties. Official antipathy to international human rights instruments has been entrenched ever since courts have found the provisions of the Universal Declaration to be non-binding." (footnotes omitted)); M. Christian Green, The "Matrioshka" Strategy: U.S. Evasion of the Spirit of the International Convention on Civil and Political Rights, 10 S. AFR. J. HUM. RTS. 357, 370-71 (1994) ("The United States has been the target of international criticism not so much for its own violations as for its unwillingness to use its position in the world to set a good example for others. The United States has a role to play as a member of the vanguard of nations trying to advocate human rights not only in theory, but in practice. It should assume this role and work for the improvement of rights in the world community rather than grudgingly ratifying treaties, while at the same time concealing their goals within layer upon layer of qualifications."); Kenneth Roth, The Charade of US Ratification of International Human Rights Treaties, I CHI. J. INT'L L. 347, $352-53$ (2000) (“Washington's cynical attitude toward international human rights law has begun to weaken the US government's voice as an advocate for human rights around the world.").

27. See KeOHANE, supra note 18.

28. Other works in this vein include LISA L. MARTIN, COERCIVE COOPERATION (1992), LISA L. Martin, Democratic COMmitmenTs (2000), Robert Jervis, Security Regimes, 36 INT'L ORG. 357 (1982), Lisa L. Martin, Institutions and Cooperation: Sanctions During the Falkland 
views states as unified principal actors that behave on the basis of selfinterest. ${ }^{29}$ It also shares neorealist assumptions that anarchy and the distribution of power among states are the underlying principles of world politics. ${ }^{30}$ Indeed, an early variant of this approach-dubbed "modified structural realism" ${ }^{31}$-differs from realism primarily in that it takes institutions, often referred to as "regimes," ${ }^{32}$ seriously. ${ }^{33}$ In this viewwhich has been variously recast as "intergovernmental institutionalism," 34 "neoliberal institutionalism," 35 and "new institutionalism," ${ }^{36}$-regimes exist in order to facilitate agreements and are complied with largely because of the rational utility-maximizing activity of states pursuing their selfinterest. Regimes thus allow countries to engage in cooperative activity that might not otherwise be possible by restraining short-term power maximization in pursuit of long-term goals. ${ }^{37}$ When it occurs, therefore,

Islands Conflict, INT'L SECURITY, Spring 1992, at 143, and Arthur A. Stein, Coordination and Collaboration: Regimes in an Anarchic World, 36 INT'L ORG. 299 (1982).

29. Robert $\mathrm{O}$. Keohane, Institutional Theory and the Realist Challenge After the Cold War, in NEOREALISM AND NEOLIBERALISM 269, 271 (David A. Baldwin ed., 1993) ("[I]nstitutionalist theory assumes that states are the principal actors in world politics and that they behave on the basis of their conceptions of their own self-interests.").

30. For a thoughtful essay exploring the relationship between neoliberal institutionalism and neorealism, see ROBERT O. KEOHANE, Neoliberal Institutionalism: A Perspective on World Politics, in INTERNATIONAL InstITUTIONS AND STATE POWER 1 (1989).

31. See Slaughter Burley, supra note 14, at 221 ("Keohane recast modified Structural Realism as 'Neoliberal Institutionalism.'"). Some significant works on compliance in this vein include KEOHANE, supra note 18, at 61-64, ROBERT O. KEOHANE \& JOSEPH S. NYE, POWER AND INTERDEPENDENCE (1977), Robert O. Keohane, The Demand for International Regimes, 36 INT'L ORG. 325 (1982), and Robert O. Keohane, Theory of World Politics: Structural Realism and Beyond, in NEOREALISM AND ITS CRITICS 158, 192-95 (Robert O. Keohane ed., 1986). Other works on this topic include ORAN R. YOUNG, INTERNATIONAL COOPERATION: BUILDING REGIMES FOR NATURAL RESOURCES AND THE ENVIRONMENT (1989), ORAN R. YOUNG, INTERNATIONAL GOVERnANCE: PROTECTING THE ENVIRONMENT IN A STATElesS SOCIETY (1994), Duncan Snidal, Coordination Versus Prisoners' Dilemma: Implications for International Cooperation and Regimes, 79 AM. POL. SCI. REV. 923 (1985), Duncan Snidal, The Game Theory of International Politics, 38 WORLD POL. 25 (1985), and Oran R. Young, The Effectiveness of Intemational Institutions: Hard Cases and Critical Variables, in GOVERNANCE WITHOUT GOVERNMENT 160 (James N. Rosenau \& Ennst-Otto Czempiel eds., 1992).

32. Stephen D. Krasner, Structural Causes and Regime Consequences: Regimes as Intervening Variables, in INTERNATIONAL REGIMES 1, 2 (Stephen D. Krasner ed., 1983) (defining "regimes" broadly as "principles, norms, rules and decision-making procedures around which actors' expectations converge in a given area"). Relatedly, Keohane and Nye define "regimes" as "sets of governing arrangements" that include "networks of rules, norms, and procedures that regularize behavior and control its effects." KEOHANE \& NYE, supra note 31, at 19.

33. For more on the evolution of modified structural realism, see Friedrich Kratochwil \& John G. Ruggie, International Organization: A State of the Art on an Art of the State, 40 INT'L ORG. 753 (1986).

34. See, e.g., Andrew Moravcsik, Negotiating the Single European Act: National Interests and Conventional Statecraft in the European Community, 45 INT'L ORG. 19, 27 (1991).

35. KEOHANE, supra note 30 , at 7.

36. Duncan Snidal, Political Economy and International Institutions, 16 INT'L REv. L. \& ECON. 121, 121 (1996).

37. See Robert O. Keohane, The Demand for International Regimes, in INTERNATIONAL REGIMES, supra note 32, at 141; Krasner, supra note 32. 
compliance with international legal rules can be explained as a winning long-term strategy to obtain self-interested ends.

As Duncan Snidal has pointed out, the increased attention to international regimes by international relations scholars did not, at least initially, signal a new focus on international law. The definition of "regimes" adopted early on by most theorists required neither formal institutions nor enforcement powers, and much of the ensuing literature on regimes focused on informal cooperation and largely ignored traditional international organizations and international law. ${ }^{38}$ Yet the most recent work in this vein has adopted a broader view of institutions ${ }^{39}$ that encompasses law as well as international legal institutions. ${ }^{40}$ In this view, legal institutions, like other institutions, are seen as "rational, negotiated responses to the problems international actors face." ${ }^{41}$

This reconceptualization of institutionalism among international relations scholars to include international law is one of many signs of the increasing convergence of international law and international relations. Until recently, however, it was left largely to international legal scholars to bring international law into the institutionalist framework. In part in response to the challenge that realism has posed to international law, legal scholars began to reconceptualize the role of law and politics in the international realm. ${ }^{42}$ In the last decade, a few legal scholars adopted the interests-based approach of institutionalism, but, unlike most international relations scholars, they placed law at the center of the analysis. ${ }^{43}$ Yet despite institutionalism's increasing acceptance, it has been applied only recently in any comprehensive way to international legal compliance. Jack Goldsmith and Eric Posner use an institutionalist approach that views compliance with international law as the result of interactions between

38. Snidal, supra note 36 , at 124 .

39. Modern work in this vein generally uses the terms "regime" and "institution" interchangeably. See, e.g., Ronald B. Mitchell \& Patricia M. Keilbach, Situation Structure and Institutional Design: Reciprocity, Coercion, and Exchange, 54 INT'L ORG. 891, 893 (2001) ("We also use the term regime interchangeably with institution.").

40. See, e.g., Barbara Koremenos et al., The Rational Design of International Institutions, 55 INT"L ORG. 761, 762-63 (2001) ("We define international institutions as explicit arrangements, negotiated among international actors, that prescribe, proscribe, and/or authorize behavior. ... The 1961 Vienna Law on Treaties is a good example."). For a collection of recent institutionalist work from the political science perspective, see the issue of International Organization in which the Koremenos article appears.

41. Koremenos et al, supra note 40 , at 768 (emphasis omitted).

42. See Slaughter Burley, supra note 14, at 209-14.

43. John K. Setear, for instance, uses an institutionalist approach informed by rational choice theory to analyze the rules of release and remediation in the law of treaties and the law of state responsibility. See John K. Setear, Responses to Breach of a Treaty and Rationalist International Relations Theory: The Rules of Release and Remediation in the Law of Treaties and the Law of State Responsibility, 83 VA. L. REV. 1 (1997); see also Setear, supra note 15 (taking an institutionalist approach to the law of treaties). 
rational, self-interested states to critique customary international law. ${ }^{44}$ And in a recent paper, Andrew T. Guzman puts forward a comprehensive institutionalist view of state action in the international realm as a function of interests and power rather than legitimacy or ideology. ${ }^{45}$ In Guzman's framework, countries take into account both direct sanctions and more indirect sanctions in the form of reputational costs, which he operationalizes through a game-theoretic model of repeated interaction, in deciding whether to comply with international legal rules. ${ }^{46}$ They weigh these costs against the benefits they will obtain from compliance, and, based on this calculus, decide how to act.

This institutionalist view of international law can be seen as a necessary and overdue counterpart to the longstanding consent-based approach to international law. International lawyers have long pointed to state consent as the central basis for the binding nature of international law. ${ }^{47}$ The consent-based approach is centered, as its name suggests, on the notion that states can bear no obligation to which they have not consented. ${ }^{48}$ Proponents of this view of international law see international treaties as simply a means for states to consent to abide by certain well-specified obligations. Once a state has accepted such an obligation, the argument continues, the obligation becomes binding and a nation must comply with it. $^{49}$ The institutionalist approach outlined above helps fill a gap in consent theory by offering a possible explanation for why, if international law binds only countries that consent to it, international law exists and has any force at all. International law exists and has force, the institutionalist would say, because it provides a means of achieving outcomes possible only through coordinated behavior. States consent to commit themselves because doing so is the only way to achieve certain goals. They then comply with

44. See Jack L. Goldsmith \& Eric A. Posner, A Theory of Customary International Law, 66 U. CHI. L. REV. 1113 (1999) (using the game-theoretic concepts that form the central focus of much international relations scholarship to provide an account of how customary international law arises, why nations comply with it, and how it changes over time).

45. GUZMAN, supra note 1.

46. Interestingly, Guzman's framework is in many ways entirely consistent with the managerial model discussed infra text accompanying notes 72-84, despite efforts by both sets of authors to emphasize the differences between the two approaches. Indeed, Guzman's work could be seen as providing a formal model of the amorphous threat of alienation from the "complex web of international arrangements" that is emphasized by Chayes and Chayes. See infra text accompanying note 82 .

47. Setear, supra note 15 , at 156 ("Most intemational lawyers would probably summarize the underlying structure of the law of treaties in a single phrase: the consent of sovereign nations.").

48. This vicw is reflected in the famous S.S. Lotus case, in which the Court of International Justice stated: "The rules of law binding upon States therefore emanate from their own free will ..." S.S. Lotus (Fr. v. Turk.), 1927 P.C.I.J. (ser. A) No. 10, at 18 (Sept. 7); see also Louis Henkin, International Law: Politics, Values and Functions, 216 RECUEIL DES COURS D' ACADEMIE DE DROIT INTERNaTIONAL 27 (1989) ("[A] State is not subject to any external authority unless it has voluntarily consented to such authority.").

49. See CHAYES \& CHAYES, supra note 1 , at 185 ("It is often said that the fundamental norm of international law is pacta sunt servanda (treaties are to be obeyed)."). 
obligations already made as long as the reputational costs and direct sanctions that would result from noncompliance outweigh the costs of continued compliance.$^{50}$ In this view, then, law provides a real constraint, but only insofar as violating it entails real costs. Law carries no weight divorced from the quantifiable sanctions and costs imposed in the case of its violation.

Explaining compliance with human rights law is almost as daunting a task for institutionalist theory as it is for realist theory. In the institutionalist view, compliance with international human rights treaties must be explained as the result of rational self-interested behavior on the part of states, the result of a reasoned weighing of the costs and benefits of alternative modes of action. But on the whole, the benefits of human rights treaty compliance appear minimal while the costs often are not. In cases where the treaty requires actions that are consistent with a country's practices at the time the treaty is adopted, the costs of compliance are obviously negligible. Treaties can, however, require fairly extensive changes in domestic institutions and practices. One of the treaties examined here, for example, requires a ratifying country to put in place "legislative, administrative, judicial or other measures to prevent acts of torture in any territory under its jurisdiction." ${ }^{51}$ Countries that are parties may thus be required to make potentially costly system-wide changes in order to bring themselves into compliance. Why might countries be willing to do this? In the institutional model, they do so because of the threat of direct sanctions or harm to reputation..$^{52}$ Direct sanctions in the form of economic or military reprisal for human rights treaty violations are so rare, however, that states are unlikely to conform their actions to a treaty solely on that basis. ${ }^{53}$ And the threat of retaliatory noncompliance with the treaty does not have the power that it does in other contexts, such as trade or arms agreements, as a threat that a treaty party will violate the treaty in retaliation for violations by another party is untenable. The institutional model is left, then, with reputation as the primary anchor of compliance for all but those countries for which compliance is costless: States comply with human rights treaties

50. For the only comprehensive work on compliance from the rationalist view, see GUZMAN, supra note 1.

51. Convention Against Torture and Other Cruel, Inhuman or Degrading Treatment or Punishment, adopted Dec. 10, 1984, art. 2, \& 1, S. TREATY DOC. No. 100-20, at 20 (1988), 1465 U.N.T.S. 85, 114 (entered into force June 26, 1987) [hereinafter Torture Convention].

52. Relatedly, states may be willing to make such changes to create and maintain a regime that satisfies their long-term interests. But such motivations depend on the existence of strong monitoring and enforcement to cause members to restrict their short-term interest-seeking to obtain long-term goals. Where direct sanctions are minimal, however, such motivations disappear.

53. See ECONOMIC SANCTIONS ReCONSIDERED 16-32 (Gary Clyde Hufbauer et al. eds., 2d ed. 1990) (listing all of the uses of economic sanctions for foreign policy purposes between 1914 and 1990 and finding that out of 119 cases of sanctions, 63 of which involved sanctions imposed only by the United States, fewer than 25 were motivated in significant part by human rights concerns). 
to obtain or maintain a reputation for compliance and hence good international citizenship. In the institutional model, therefore, if countries change their behavior in response to human rights treaties, it is largely because of concern for their reputation.

\section{Liberalism: Compliance as By-Product of Domestic Politics}

A third rational actor model of international law compliance discards the assumption, which undergirds realism and institutionalism, that states are properly viewed as unitary rational agents. Termed "institutional liberalism" (or sometimes "liberal institutionalism"), this approach disaggregates the state and places the focus on domestic political processes. The approach finds its intellectual antecedents in the work of Immanuel Kant, in particular his essay Perpetual Peace. ${ }^{54}$ In the essay, Kant argues that the first condition of perpetual peace is that "the civil construction of every nation should be republican," ${ }^{55}$ because republican governments (i.e., representative democracies) rely on the consent of the citizens to engage in war and must therefore "consider all its calamities before committing themselves to so risky a game." ${ }^{56}$ Kant's claim was later taken up by international relations scholars who claimed that although "liberal" states engage in war, they do not engage in war with one another. ${ }^{57}$ In its modern iteration, liberal international relations theory has come to stand for the straightforward proposition that domestic politics matter. ${ }^{58}$

The liberal approach holds that interstate politics are much more complex than realists and institutionalists acknowledge. States are not unitary, but rather are the sum of many different parts. Understanding those parts-the political institutions, interest groups, and state actors-is essential to fully understanding state action on the world stage. As Andrew Moravcsik puts it: "Societal ideas, interests, and institutions influence state behavior by shaping state preferences, that is, the fundamental social purposes underlying the strategic calculations of governments." 59 In other

54. Immanuel Kant, Perpetual Peace, in Perpetual Peace and Other Essays on POLITICS, HISTORY, AND MORALS 107 (Ted Humphrey trans., Hackett Publ'g Co. 1983) (1795).

55. Id. at 112 .

56. Id. at 113 .

57. The central work on this topic is Michael W. Doyle, Kant, Liberal Legacies, and Foreign Affairs, 12 PHIL. \& PUB. AFF. 205 (1983). Doyle's findings were confirmed by a series of empirical studies, including most notably Zeev Maoz \& Nasrin Abdolali, Regime Types and Intermational Conflict, 1816-1976, 33 J. CONFLICT RESOL. 3 (1989).

58. GRAHAM AlLISON \& PHILIP ZELIKOW, ESSENCE OF DECISION 39 (2d ed. 1999).

59. Andrew Moravcsik, Taking Preferences Seriously: A Liberal Theory of International Politics, 51 INT'L ORG. 513, 513 (1997). 
words, one cannot fully understand state decisions in the international realm without understanding the domestic politics that underlie them. ${ }^{60}$

Anne-Marie Slaughter has taken the lead in bringing the liberalist view to the attention of legal scholars. She argues in an early piece in this vein that just as liberal states act differently toward one another in waging war, they act differently toward one another in the legal realm. ${ }^{61}$ From this insight, she constructs what she terms a "liberal internationalist model" of transnational legal relations that seeks to explain why and how relations among liberal states differ from those between liberal and nonliberal states. In short, she argues that because of their political structure, liberal states are more likely to resolve disputes with one another peacefully in the "zone of law" than they are when the disputes are with nonliberal states. ${ }^{62}$ In a more recent article, Slaughter and her coauthor Laurence Helfer make a similar argument with regard to the effectiveness of international or "supranational" adjudication, which, although distinct from treaty law, bears some important similarities. ${ }^{63}$ They argue that liberal democratic governments will be more likely to comply with supranational legal judgments than are other states because international legal obligations mobilize domestic interest groups that in turn pressure the government to comply. ${ }^{64}$ More specifically, they claim that "government institutions committed to both the rule of law and separation of powers ... in systems where the individuals themselves are ultimately sovereign[] are primed to be the most receptive to the tools that a supranational tribunal has at its disposal." ${ }^{65}$ Thus compliance with international law comes, in the liberalist view, from the favorable effect of international law and legal institutions on domestic interests-a phenomenon not limited to, but more likely to be found in, liberal states.

Liberal theory is susceptible to the charge that although it can provide explanations for government actions after the fact, it has difficulty generating predictions ex ante. Indeed, at an extreme, the theory can be reduced to the unenlightening truism that if a country acts in a particular

60. See Stephan Haggard \& Beth A. Simmons, Theories of International Regimes, 41 INT'L ORG. 491, 499 (1987) (arguing that realist and institutionalist theories "downplay the central insight of interdependence theorists: foreign policy is integrally related to domestic structures and processes").

61. Anne-Maric Burley, Law Among Liberal States: Liberal Intermationalism and the Act of State Doctrine, 92 COLUM. L. REv. 1907, 1920-21 (1992); see Anne-Marie Slaughter, International Law in a World of Liberal States, 6 EUR. J. INT'L L. 503 (1995); Anne-Marie Slaughter, The Liberal Agenda for Peace: International Relations Theory and the Future of the United Nations, 4 TRANSNAT'L L. \& CONTEMP. PROBS. 377 (1995); Slaughter Burley, supra note 14.

62. Burley, supra note 61, at 1916-22.

63. Laurence R. Helfer \& Anne-Marie Slaughter, Toward a Theory of Effective Supranational Adjudication, 107 YALE L.J. 273, 278 (1997).

64. Id. at 331-35.

65. Id at 334 . 
way, it must be because domestic politics made it do so. Yet it is arguably better suited to explaining compliance with human rights treaties than are either of the other two rational actor models. In the liberalist view, human rights treaties, like other sources of international law, must affect state action by affecting domestic interests. A state's ratification of a human rights treaty creates an international legal obligation that domestic interest groups can use to mobilize pressure on domestic political institutions to take action in conformance with that obligation. This process is particularly strong in liberal states, which are structured to translate domestic interests into state action. Moreover, according to this view, such states are more likely to abide by human rights treaties because they are more likely to be receptive to the claim that once a treaty is consented to, it creates an obligation that must be obeyed. ${ }^{66}$ Liberalism thus generates a testable hypothesis: Liberal nations are more likely to comply than others, and treaties are more likely to lead to favorable changes in the practices of liberal nations than in the practices of others.

Andrew Moravcsik's recent work on human rights treaty ratification from the perspective of a variant of the liberal approach-termed "republican liberalism"- gives reason to suspect that the story regarding human rights treaty compliance may be more complicated than the above analysis suggests. Examining the formation of the European Convention on Human Rights, ${ }^{67}$ Moravcsik argues that newly established and potentially unstable democracies are more likely to be supporters of binding human rights regimes than are either established democracies or nondemocracies. ${ }^{68}$ They do so, he explains, in order to "lock in" democratic rule through the enforcement of human rights. ${ }^{69}$ If Moravcsik is correct and if, as one might reasonably hypothesize, new democracies tend to have worse human rights practices than do more established democracies,$^{70}$ then it is possible that

66. Cf. Helfer \& Slaughter, supra note 63 (making a similar argument with regard to supranational adjudication).

67. Convention for the Protection of Human Rights and Fundamental Freedoms, opened for signature Nov. 4, 1950, 213 U.N.T.S. 221 (entered into force Sept. 3, 1953) [hereinafter European Convention on Human Rights].

68. See Moravcsik, supra note 25. This thesis will be much more fully tested in a work in progress, Oona A. Hathaway, The Puzzle of Human Rights Treaty Formation: When and Why Do Nations Join Human Rights Regimes? (Jan. 2002) (unpublished manuscript, on file with author).

69. Moravcsik, supra note 25 , at 228.

70. I find support for the supposition that newly established democracies, defined as countries with an 8 to 10 point democracy rating on a scale of 1 to 10 that have been in place fewer than thirty years, see infra Appendix B, Section G; see also Moravcsik, supra note 25, at 231-32 (defining newly established democracies - in a study of negotiations that took place in 1950-as those established between 1920 and 1950), have worse practices than established democracies. In my data (in which higher ratings reflect worse practices), established democracies have Torture ratings of 1.71 , compared to 2.50 for newly established democracies; Fair Trial ratings of 1.23 , compared to 1.96 for newly established democracies; Civil Liberty ratings of 1.35 , compared to 2.54 for newly established democracies; Genocide ratings of 0 , compared to 0.035 for newly established democracies; and $89 \%$ Men in Parliament, compared to 95\% for newly established 
there is an unexpected selection effect that would lead to lower apparent rates of compliance with human rights treaties. Of course, Moravcsik's argument regarding countries' reasons for joining treaties does not suggest that human rights treaties worsen the practices of newly established democracies. Indeed, the argument appears to rest on the assumption, shared by others in the liberal camp, that democracies will be likely to exhibit better human rights practices if they have signed a treaty than if they have not. If this were not the case, it is not clear why domestic actors would see treaty ratification as a means of "locking in" democratic rule. ${ }^{71}$ Thus, while Moravcsik's republican liberal theory suggests a more nuanced story regarding expected patterns of compliance, it too appears to predict that human rights treaties will be more effective in changing behavior in liberal nations than in others.

\section{B. Normative Models}

The theories of international law compliance that I group under the label "normative models" share the conviction that the interest-based rationalist models miss something fundamental about the international legal framework: the persuasive power of legitimate legal obligations. Scholars adopting this approach argue that state decisions cannot be explained simply by calculations of geopolitical or economic interests or even the relative power of domestic political groups. A complete description of state action in the international realm, they argue, requires an understanding of the influence and importance of ideas. How and why ideas matter, however, remains a source of disagreement. I describe below three separate models that seek to explain the influence of ideas on international law compliance: the managerial model, the fairness model, and the transnational legal process model.

\section{The Managerial Model: Compliance Is Due to a Norm of Compliance and Fostered by Persuasive Discourse}

Perhaps the most prominent normative approach, called the "managerial model" by its progenitors Abram and Antonia Chayes, places the spotlight on the process of international discourse. This view, which is informed by and draws together Chayes and Chayes's extensive practical international law experience, teaching, and writing, adopts a "cooperative, problem-solving approach" to international law compliance, as against

democracies. See infra Section II.A (describing human rights measures). I do not find any evidence, however, that newly established democracies ratify human rights treaties more readily than do established democracies. See infra note 184.

71. Moravcsik, supra note 25, at 228. 
what they term the "enforcement model" of compliance. ${ }^{72}$ The common belief that it is necessary for a treaty to incorporate coercive enforcement measures in order to achieve a high rate of compliance reflects, they claim, "an easy but incorrect analogy to domestic legal systems." ${ }^{73}$ Coercive economic or military sanctions for treaty violations cannot be the primary mechanism of obtaining compliance with treaties. Such sanctions are too politically and economically costly and often ineffective at changing behavior ${ }^{74}$ Moreover, because they are so costly, they are rarely administered and tend to be intermittent and ad hoc, and hence unlikely to serve as legitimate, effective deterrents. ${ }^{75}$

Instead of assuming that international legal obligations must be backed up with threats in order to be effective, Chayes and Chayes begin with the expectation that states have a propensity to comply with their international treaty obligations. This propensity to comply comes about in large part, they claim, because treaties generate legal norms, which necessarily carry a widely accepted obligation of obedience. ${ }^{76}$ Norms are obeyed not simply because of the penalties a violation carries; rather, the obligation to obey legal norms exists even in the absence of a threat of reprisal. ${ }^{77}$ Although it is difficult to explain why countries respond to this sense of obligation, Chayes and Chayes argue that it is no more difficult than explaining why they would respond to self-interest. ${ }^{78}$ In short, then, states obey treaties largely because their prior agreement to do so has created a normative obligation they cannot ignore-states accept and abide by the notion of pacta sunt servanda. ${ }^{79}$

When noncompliance occurs, in this view, it is usually not because of a calculated weighing of costs and benefits of treaty adherence but instead because of insufficient information or capacity on the part of the state. ${ }^{80}$ To

72. CHAYES \& CHAYES, supra note 1, at 3. For a strong critique of this approach and a defense of the enforcement model, see Downs et al., supra note 4.

73. CHAYES \& CHAYES, supra note 1 , at 2.

74. Id. at 2-3.

75. For more on Chayes and Chayes's views of military and economic sanctions, see id. at 34-67.

76. The assumption that countries tend to comply with international law is, they argue, supported by three types of considerations: efficiency, interests, and norms. Compliance with established treaty norms is efficient; treaties supply a standard operating procedure by which government actors can operate. Because a treaty is a consensual instrument, it must also serve the parties' interests, as they otherwise would not have agreed to it. They therefore must have some interest in maintaining its viability. And, finally, treaties are accepted to be legally binding instruments, which are obeyed because of shared norms of law abidance. Id. at 3-9.

77. Id. at 116 .

78. Id. at 118 .

79. "The rule that agreements and stipulations, esp. those contained in treaties, must be observed." BLACK's LAW DICTIONARY 1109 (7th ed. 1999).

80. Specifically, noncompliance occurs because of "ambiguity and indeterminacy of treaty language," "limitations on the capacity of parties to carry out their undertakings," and time lags or failure of the treaty to adapt to changing conditions. CHAYES \& CHAYES, supra note 1, at 9-17. 
combat noncompliance, Chayes and Chayes therefore advocate a strategy based not on coercion but on "managing" compliance. This multifaceted approach focuses on ensuring transparency regarding the requirements of the regime and the parties' performance under it, creating a dispute settlement mechanism, and building capacity for compliance. These elements merge into a broader effort to persuade noncomplying countries to act in accordance with the law. It is this persuasion, they argue, that is central to treaty compliance. As they put it, "[T]he fundamental instrument for maintaining compliance with treaties at an acceptable level is an iterative process of discourse among the parties, the treaty organization, and the wider public." 81 This process is effective not because of the threat of direct penal sanctions but rather because of the threat of alienation from the "complex web of international arrangements" that have become central to most nations' security and economic well-being. ${ }^{82}$ In this view, therefore, persuasive discourse in a system where there is a norm of treaty compliance is the key to obtaining and maintaining international law compliance.

All of the normative theories-and the managerial model is no exception-share the fundamental claim that it is the transformative power of normative discourse and repeated interactions between transnational actors, rather than the calculation of political, military, or financial advantage, that is responsible for the formation and continuation of human rights regimes. Norms, in other words, have a causal influence on human rights regimes. International cooperation regarding human rights occurs, it is claimed, because of the persuasive power of normative beliefs regarding human rights. This process of norm proliferation and socialization is aided by the human rights activism of nongovernmental organizations, which motivate international discourse on human rights, establish international networks of people and institutions to monitor human rights violations, and rally public opinion in support of efforts to convince governments to create human rights regimes and press other states to join them. ${ }^{83}$ Normative theorists thus reject the notion that governments abide by human rights treaties for instrumental reasons. The fundamental motive behind these

81. Id. at 25 .

82. Id. at 27 .

83. See MARTHA FinNemore, NATIONAl INTERESTS IN INTERNATIONAL SOCIETY (1996);

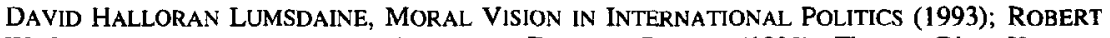
W. MCElroY, MORALITY AND AMERICAN ForeIGN POLICY (1992); Thomas Risse-Kappen, Ideas Do Not Float Freely: Transnational Coalitions, Domestic Structures, and the End of the Cold War, 48 INT'L ORG. 185 (1994); Kathryn Sikkink, The Power of Principled Ideas: Human Rights Policies in the United States and Western Europe, in IDEAS AND FOREIGN POLICY 139 (Judith Goldstein \& Robert O. Keohane eds., 1993). 
treaties is not rational adaptation, they claim, but transnational socialization. ${ }^{84}$

The managerial model provides some specific arguments regarding compliance that can be used to deduce predictions regarding state compliance with human rights regimes. In particular, it predicts that countries have a propensity to comply with treaties and that noncompliance will be limited to situations in which there are ambiguities, limitations on capacity, or temporal issues. The sources of noncompliance identified by Chayes and Chayes are indisputably correct-countries cannot immediately comply with legal obligations they do not understand, with which they do not have the capacity to comply, or that take time to implement. What is more debatable - and hence tested in this Article-is the assertion that compliance with human rights treaties will generally exist where these sources of noncompliance are absent.

\section{The Fairness Model: Compliance Occurs when Rules Are Legitimate and Just}

A prominent strand of the normative explanatory framework finds the source of support for international regimes in the legitimacy of the norms and rules that compose them. ${ }^{85}$ Phillip Trimble, for example, argues that international law is a form of "rhetoric" whose persuasiveness depends on its legitimacy, which in turn depends on the process whereby it arises, its consistency with accepted norms, and its perceived fairness and transparency. ${ }^{86}$

In the most recent comprehensive statement of this approach, Thomas Franck claims that the key element explaining treaty adherence and compliance is fairness. ${ }^{87}$ The question Franck poses is not, "Do nations comply?," but rather "[I]s international law fair?" 88 This is the central question, he claims, because rules that are not fair exert little "compliance pull." 89 In order to be legitimate or fair, rules must be both substantively and procedurally fair-their ends must lead to distributive justice and they "must be arrived at discursively in accordance with what is accepted by the parties as right process." 90

84. Jack Donnelly, International Human Rights: A Regime Analysis, 40 INT'L ORg. 599 (1986); Martha Finnemore \& Kathryn Sikkink, International Norm Dynamics and Political Change, 52 INT'L ORG. 887 (1998).

85. See, e.g., Bruce Russett, Grasping the Democratic Peace (1993).

86. Phillip R. Trimble, International Law, World Order, and Critical Legal Studies, 42 STAN.

L. REV. 811,833 (1990) (book review).

87. THOMAS M. FRANCK, FAIRNESS IN INTERNATIONAL LAW AND INSTITUTIONS (1995).

88. Id. at 7 .

89. Thomas M. Franck, Legitimacy in the International System, 82 AM. J. INT'L L. 705, 712 (1988).

90. FRANCK, supra note 87 , at 7. 
The fairness model, like the managerial model, thus points not to state calculations of self-interest as the source of state decisions to act consistently with international legal obligations, but instead to the perceived fairness of the legal obligations. Compliance with international law, in this view, is traced to the widespread normative acceptance of international rules, which in turn reflects the consistency of the rules with widely held values and the legitimacy of the rulemaking process. ${ }^{91}$ Specifically, Franck claims that four primary factors determine the legitimacy of a rule and thus state compliance with it. ${ }^{92}$ First, there must be "determinacy" so that the rule's requirements are transparent and its fairness thereby "made manifest" (this is an obvious counterpart to Chayes and Chayes's claim that "ambiguity" is a major source of noncompliance). ${ }^{93}$ Second, the rule must have attributes that signal that it is an important part of a system of social order, a characteristic Franck labels "symbolic validation." "Third, the rule must exhibit "coherence"-it must treat like cases alike and "relate[] in a principled fashion to other rules of the same system." ${ }^{95}$ Finally, the rule must be closely connected to (i.e., "adhere to") the secondary rules of process used to interpret and apply rules of international obligation. ${ }^{96}$

In this framework, the greatest strength of human rights regimes is arguably their symbolic validation. As Franck notes, the violation of any aspect of human rights has assumed the "greater gravity of a trespass against a major public policy of the community." ${ }^{97}$ Human rights rules also appear to be supported by the procedural and institutional framework of the international community (thereby meeting Franck's "adherence" condition). Human rights treaties vary, however, in their determinacy and coherence. Franck argues that the process put into place by the International Covenant on Civil and Political Rights ${ }^{98}$ has caused "[a] perception of fairness" to begin to displace the "opprobrium of expedient politics in human rights discourse" ${ }^{99}$ because its provision for case-by-case review of alleged violations by the quasi-judicial Human Rights Committee of independent experts means that the rules are more impartially applied. This impartial application, in turn, creates greater coherence and determinacy in

91. Franck, supra note 89.

92. FRANCK, supra note 87 , at 30 .

93. $I d$. at 99 ("The determinacy of a rule directly affects its legitimacy because in increasing the rule's transparency, its faimess is made manifest, and thus its compliance pull on members of the international community is increased."); see $i d$. at 30-34.

94. Id. at 34-38.

95. $I d$. at 38 .

96. Id. at $41-46$.

97. Id. at 124 .

98. International Covenant on Civil and Political Rights, adopted Dec. 19, 1966, S. EXEC. DoC. E, 95-2, at 23 (1978), 999 U.N.T.S. 171 (entered into force Mar. 23, 1976) [hereinafter Covenant on Civil and Political Rights].

99. FRANCK, supra note 87, at 103. 
the requirements of the treaty. ${ }^{100}$ But Franck's analysis may be too sanguine regarding the effectiveness of the provisions of the Covenant on Civil and Political Rights and other similar human rights treaties. ${ }^{101}$ While the human rights system may be legitimate in form, it appears less so in practice, and hence its compliance pull must be less strong under the fairness framework than Franck estimates. Nonetheless, the fairness theory appears to argue, as does Franck himself, that human rights treaties are largely fair and therefore likely to foster compliance.

\section{The Transnational Legal Process Model: Compliance Occurs Because Norms Are Internalized}

The most recent addition to the normative theoretical framework is Harold Koh's theory of transnational legal process. ${ }^{102}$ Koh shares with Franck and Chayes and Chayes a conviction that the secret to better enforcement of international law is not coerced compliance, but voluntary obedience. He fills a logical gap left by these theorists by providing an explanatory framework for understanding how and why the process of norm-internalization that he considers the key to compliance, or obedience, occurs. Koh claims that the process of norm-internalization has three phases. It begins when one or more transnational actors provoke an interaction with another, thereby requiring enunciation of the norm applicable to the interaction. The interaction generates a legal rule that can be used to guide future transnational interactions. Over time, a series of such interactions causes the norms to become internalized, and eventually, this iterative process leads to the reconstitution of the interests and identities of the participants. ${ }^{103}$

100. Id. at 104-05.

101. There are 1203 overdue reports in the human rights treaty system, while only 1613 reports have ever been considered. Seventy-one percent of all state parties to human rights treaties have overdue reports, and 110 states have five or more overdue reports. ANNE F. BAYEFSKY, THE UN HUMAN RIGHTS TREATY SYSTEM: UNIVERSALITY AT THE CROSSROADS 8 (2000), http://www.yorku.ca/hrights/Report/finalreport.pdf; see Philip Alston, Final Report on Enhancing the Long-Term Effectiveness of the United Nations Human Rights Treaty System, U.N. ESCOR, 53d Sess., Agenda Item 15, II 37, U.N. Doc. EJCN.4/1997/74 (1996). In its 1999 Annual Report, the Human Rights Committee reported that since 1977, it had received 873 communications (despite the fact that the Optional Protocol that governs the individual complaint system under the treaty covers over one billion people around the world). Of those, the Committee had concluded 328 by issuing its views, declared 267 inadmissible, discontinued 129, and not yet concluded 149. See International Human Rights in CONTEXT 740 (Henry J. Steiner \& Philip Alston eds., 2d ed. 2000).

102. Koh, supra note 1; see Harold Hongju Koh, The 1998 Frankel Lecture: Bringing International Law Home, 35 Hous. L. REV. 623 (1998) [hereinafter Koh, Bringing International Law Home]; Harold Hongju Koh, How Is International Human Rights Law Enforced?, 74 IND. L.J. 1397 (1998) [hereinafter Koh, How Is International Human Rights Law Enforced?].

103. Koh, supra note 1 , at 2646. 
Transnational legal process, in contrast with the two other models of normative theory discussed above, opens the black box of the state. The process of norm-internalization on which the theory rests occurs via transnational actors-usually foreign policy personnel of the governments involved, private norm entrepreneurs, and nongovernmental organizations, which form an "epistemic community" to address a legal issue. ${ }^{104}$ As transnational actors interact, Koh argues, they generate patterns of activity that lead to norms of conduct, which are in turn internalized into domestic structures through executive, legislative, and judicial action. Domestic institutions thereby enmesh international legal norms, generating selfreinforcing patterns of compliance. In this way, repeated participation in the transnational legal process leads nations to obey international law. Obedience to international law thus comes about not simply because of external enforcement of legal rules, but because repeated interaction leads nations gradually to internalize legal rules. Indeed, in Koh's view, "True compliance is not so much the result of externally imposed sanctions ... as internally felt norms." 105

The transnational legal process framework presents a coherent explanation for compliance with human rights regimes. Noting that in the area of human rights, national governments are often unwilling to enforce treaties against one another, Koh argues that the transnational legal process approach offers a means of combating this apathy. To encourage interaction, more actors, including intergovernmental and nongovernmental organizations and private parties, ought to be encouraged to participate in the process. ${ }^{106}$ And to produce interpretations of human rights norms, fora dedicated to this purpose should be created or adapted from existing institutions. ${ }^{107}$ Finally, domestic internalization of the norms can occur through a variety of means, including incorporation into the legal system through judicial interpretation, acceptance by political elites, and the like. ${ }^{108}$ Indeed, Koh exhorts those seeking to encourage countries to abide by international human rights law to use all the tools at their disposal-not simply external power and coercion, not simply self-interest of states, not simply encouragement of liberal legal identity, not simply promotion of shared values, and not simply facilitation of legal process, but all of these at once. ${ }^{109}$

The approach of transnational legal process helps explain why human rights norms are obeyed even in the face of contrary self-interest on the part

104. Id. at 2648.

105. Koh, How Is International Human Rights Law Enforced?, supra note 102, at 1407.

106. Koh, supra note 1 , at 2656.

107. Id.

108. Id. at 2656-57.

109. Koh, How Is International Human Rights Law Enforced?, supra note 102, at 1407-08. 
of participating states. It fosters better understanding of the process by which international legal norms can be generated and internalized into domestic legal systems and thereby provides a guide for those seeking to bring about changes in country practices on an international scale. ${ }^{110}$ However, in providing a very detailed explanation for compliance, the transnational legal process model loses some predictive power. Once a norm has been internalized and obeyed, the transnational legal process model provides a means of tracing the players and process that led the country to obey. Yet it is difficult to predict in advance which norms will become internalized through the three-step process of interaction, interpretation, and internalization. In its current form, which awaits booklength treatment, the theory does not tell us what characteristics of a norm or country lead to compliance. Nor does it explain why norms in favor of compliance, rather than against it, are internalized. While this tradeoff of predictive value for explanatory value is undoubtedly intentional, it does cabin the uses to which the theory can be put. ${ }^{111}$

The rationalist and normative strands of international law and international relations scholarship recounted here provide coherent contrasting accounts of international legal compliance. The next Part tests the claims of the two approaches and their variants in the area of human rights using a comprehensive analysis of countries' human rights practices and their relationship to human rights treaty ratification. The results, while necessarily limited to the area of human rights treaties, carry implications for theories of treaty compliance more generally.

\section{TeSting COMPLIANCE}

The analysis presented in this Part confronts the question: Do human rights treaties make a difference in countries' human rights practices? Normative theory suggests that they should unless specified sources of noncompliance, such as insufficient information or incapacity on the part of the state, are present. ${ }^{112}$ Rationalist theory is more equivocal, with each variant making slightly different predictions regarding the expected relationship between treaty ratification and human rights practices. Realist

110. Indeed, Koh has put forward a guide for United States human rights policy for the twenty-first century that draws on and builds upon his transnational legal process framework. See Harold Hongju Koh, A United States Human Rights Policy for the 21st Century, 46 ST. LoUIS U. L.J. 293 (2002). More so than any of the theories outlined in this Article, Koh's theory of transnational legal process speaks directly to those who seek, as he puts it, to "bring international law home"-the lawyers, activists, politicians, and others who carry out the process of normintemalization. Koh, Bringing International Law Home, supra note 102, at 680-81.

111. See Jacob S. Hacker, Learning from Defeat?: Political Analysis and the Failure of Health Care Reform in the United States, 31 BRIT. J. POL. SCI. 61, 91 -92 (2001) (discussing the difference between predictability and explainability).

112. See, e.g., supra text accompanying notes 76, 86-92. 
theory, which views such treaties largely as cheap talk, would predict little or no relationship between ratification and practice. Institutionalists, on the other hand, would expect treaty ratification to be associated with better human rights practices. If the reputational benefits of treaty compliance are the primary source of country compliance, as Andrew Guzman's model suggests, one would expect countries that ratify human rights treaties to comply with their requirements but not if doing so requires changes in practices. Indeed, in this view, it appears likely that only countries for whom compliance is costless or nearly costless will ratify. Finally, liberalists would predict that for democracies at least, treaty ratification will be associated with better human rights practices. The question this Part examines thus provides a good starting point for testing the relative strengths of the theories against the empirical evidence.

The analysis in this Part explores two related issues-compliance and effectiveness. I begin by discussing the challenges inherent in a project that seeks to address these two issues and the ways in which I have attempted to meet these challenges. I then turn to the quantitative analyses. I first examine whether countries comply with or adhere to the requirements of the human rights treaties they have joined. ${ }^{113} \mathrm{I}$ then address the more difficult question of whether treaties are effective in improving countries' human rights practices.

\section{A. The Challenges of Measuring Compliance and Effectiveness}

Any study seeking to evaluate compliance with and effectiveness of human rights treaties faces a serious measurement problem. This problem has two aspects. First, compliance and effectiveness are imprecise terms that can be open to multiple interpretations. It is therefore important to be clear about what it is that the study seeks to measure. Second, measuring state human rights practices is complicated by the relative dearth of comprehensive information. Indeed, a central difficulty that all quantitative studies of human rights practices face-and the present one is unfortunately no exception-is the relative scarcity of accurate information on state practices. ${ }^{114}$

113. The data sources for treaty ratification are described in Appendix B. In this Article, I look only at whether a country has ratified a treaty. I do not take into account any reservations the country may have made to the treaty. I do this both because quantifying reservations in a consistent way would be extremely difficult and because a reservation to a treaty is only valid if it does not defeat the object and purpose of the treaty. Vienna Convention on the Law of Treaties, opened for signature May 23, 1969, art. 19, S. EXEC. DOC. L, 92-1, at 16 (1971), 1155 U.N.T.S. $331,336-37$. A reservation that falls within this limitation ought not significantly affect the reserving country's human rights practices covered by the treaty.

114. See, e.g., Robert E. Robertson, Measuring State Compliance with the Obligation To Devote the "Maximum Available Resources" to Realizing Economic, Sociah and Cultural Rights, 16 HUM. RTS. Q. 693, 703-13 (1994) (discussing the difficulties of measuring compliance with 
I begin with the more tractable challenge of specifying the relationship between treaties and state behavior. I explore two facets of what traditionally has been referred to collectively as "compliance"compliance and effectiveness. ${ }^{115}$ The notion of compliance also has several different dimensions: compliance with procedural obligations, such as the requirement to report; compliance with substantive obligations outlined in the treaty; and compliance with the spirit of the treaty. ${ }^{16}$ This study focuses attention on the last two of these forms of compliance. Because I aim to measure compliance with a treaty's letter and spirit, I focus on countries' actual treatment of their inhabitants, rather than their cooperation with procedural requirements or with the legislative implementation requirements of the treaty. ${ }^{177}$ In principle, therefore, determining whether a country complies with a treaty merely requires comparing the relevant activity with the treaty's requirements. Yet this is not as simple as it at first seems. To begin with, compliance is not an on-off switch; it is an elastic concept that allows for different gradations. ${ }^{118}$ Laws often incorporate a

certain provisions of the International Covenant on Economic, Social and Cultural Rights); see also Jack Donnelly \& Rhoda E. Howard, Assessing National Human Rights Performance: A Theoretical Framework, 10 HUM. RTS. Q. 214 (1988) (seeking to establish a framework for assessing states' human rights performance); James M. McCormick \& Neil J. Mitchell, Human Rights Violations, Umbrella Concepts, and Empirical Analysis, 49 WORLD POL. 510 (1997) (arguing for the use of a disaggregated, multidimensional measure of human rights violations); Herbert F. Spirer, Violations of Human Rights-How Many?: The Statistical Problems of Measuring Such Infractions Are Tough, but Statistical Science Is Equal to It, 49 AM. J. ECON. \& SOC. 199 (1990) (reviewing statistical problems encountered in measuring and analyzing human rights violations). The four most prominent sources of comprehensive cross-national time series information on a broad spectrum of human rights practices are the United States Department of State Country Reports on Human Rights, Human Rights Watch's reports, Amnesty Intemational's Country Reports, and Freedom House's Freedom in the World reports. (There are, of course, many other sources of data on human rights practices, but most do not cover all or nearly all countries in the world over a substantial period of time, as is necessary for the instant analysis.) Each of these data sources has advantages and drawbacks. The State Department reports, for instance, have been charged with political bias. E.g., David Carleton \& Michael Stohl, The Role of Human Rights in U.S. Foreign Assistance Policy: A Critique and Reappraisal, 31 AM. J. POL. SCI. 1002, 1007 (1987) (citing and briefly discussing reports of Americas Watch, Helsinki Watch, and the Lawyers Committee for International Human Rights and critiquing the State Department reports for political bias). The Freedom House reports, which are the only ones of the four to provide a quantifiable measure of human rights practices, have been criticized for lack of replicability and reliability. Christopher Mitchell et al., State Terrorism: Issues of Concept and Measurement, in GOVERNMENT VIOLENCE AND REPRESSION 1, 20 (Michael Stohl \& George A. Lopez eds., 1986). The Amnesty International and Human Rights Watch reports are relatively short and do not cover every country every year, making them a poor source for social scientific inquiry.

115. Weiss \& Jacobson, supra note 2, at 4-6 (disaggregating the notions of implementation, compliance, and effectiveness).

116. Id. at 4 (identifying various dimensions of compliance).

117. This focus on state practice pernits a comparison of the practices of ratifying and nonratifying countries. A broader focus would make a comparison difficult, as nonratifying countries cannot necessarily be expected to comply with the procedural or legislative requirements of a treaty. This narrower focus also centers attention on what ought to be the central concern-whether treaties make a difference in people's lives.

118. See CHAYES \& CHAYES, supra note 1 , at 17. 
zone within which behavior is considered to "conform" even if it is not consistent with the letter of the legal obligation. And there are different levels of nonconformance: Just as traveling at forty miles per hour over the speed limit is different in kind from traveling ten miles per hour over the speed limit, so too is rampant corruption in a court system different in kind from occasional failure to bring accused persons to trial quickly. Compliance with human rights treaties must therefore be defined on a continuum based on the degree to which behavior deviates from the legal requirements of the treaties.

Effectiveness is directly related to, but distinct from, compliance. A country may comply with a treaty-its actions comport with the requirements of a treaty - but the treaty may nonetheless be ineffective in changing its practices. In evaluating effectiveness, I therefore seek to determine whether there is any evidence indicating that countries' practices are different when they have ratified a given treaty than they would have been expected to be absent ratification.

The second and more difficult challenge encountered in a study of compliance and effectiveness of human rights treaties is posed by the task of measuring countries' practices. I choose in this study to examine five subject areas-genocide, torture, civil liberty, fair and public trials, and political representation of women-that cover a broad spectrum of human rights and draw their measures from a variety of sources. Genocide and torture are the most widely prohibited human rights violations. Both are the subject of international treaty instruments and are among the few human rights that are virtually universally acknowledged to be a violation of customary international law. ${ }^{119}$ Indeed, the norms against torture and genocide are widely regarded as jus cogens and therefore nonderogable. ${ }^{120}$ The norms against torture and genocide are also relatively clear and precisely specified. ${ }^{121}$ Next on the spectrum are civil liberty (encompassing freedom of expression, freedom of association, the independence of the judiciary, rule of law, and personal autonomy) and the right to a fair and

119. See Restatement (ThiRd) of FOREIGN Rflations Law of the United States $\S 702(1986)$.

120. Filartiga v. Pena-Irala, 630 F.2d 876, 890 (2d Cir. 1980) (“[T]he torturer has becomelike the pirate and slave trader before him-hostis humani generis, an enemy of all mankind."); Regina v. Bartle, ex parte Pinochet, [2000] 1 A.C. 147 (H.L. 1999) (recognizing the inviolability of the international prohibition against torture and therefore allowing extradition proceedings against General Augusto Pinochet to go forward); Ellen L. Lutz \& Kathryn Sikkink, International Human Rights Law and Practice in Latin America, 54 INT'L ORG. 633, 634 (2000); Eduardo Moisés Peñalver, Redistributing Property: Natural Law, International Norms, and the Property Reforms of the Cuban Revolution, 52 FLA. L. REV. 107, 138 (2000) ("[C]ommon examples of [j]us cogens include the duty to respect human rights and the prohibition of genocide.").

121. Torture Convention, supra note 51, art. 1, S. TrEATY DOC. No. 100-20, at 19, 1465 U.N.T.S. at 113-14 (defining torture); Convention on the Prevention and Punishment of the Crime of Genocide, adopted Dec. 9, 1948, art. 2, S. ExEC. Doc. O, 81-1, at 7 (1949), 78 U.N.T.S. 277, 280 (entered into force Jan. 12, 1951) [hereinafter Genocide Convention] (defining genocide). 
public trial, both of which are covered by decades-old international treaty instruments, but neither of which is regarded as a norm of customary law. ${ }^{122}$ Finally, I examine the influence of treaties on one of the least entrenched international human rights-women's political equality. ${ }^{123}$

I choose to examine these five areas of human rights in part because they permit me to minimize two of the three factors contributing to noncompliance outlined by Chayes and Chayes-ambiguity and lack of capacity. I seek to address ambiguity by focusing my analysis on treaties for which the interpretation of the broad requirements of the treaty is widely shared (though particular applications of those requirements may be contested), and I resolve any significant differences of legal opinion on the requirements of the treaty in favor of the countries under study. ${ }^{124}$ With the exception of women's political equality, the areas on which I focus are ones in which the treaty governs only activity by the state or its agents, thus enhancing state capacity to effect the required changes. ${ }^{125}$ Of course, simply because an activity is carried out by state actors does not necessarily mean that it is within the capacity of the state to change it, but it does suggest that the state's capacity will be greater than where the state must affect the activity of private actors in order to comply. I address the third source of noncompliance-the time lag between undertaking and performance-by tracking countries over a nearly forty-year period. I likewise seek to eliminate the related sources of noncompliance identified by Franck by selecting cases in part because they largely satisfy the determinacy condition (the obligations of the treaty are clearly specified) and the

122. See infra text accompanying notes $141-157$ (describing the data on fair trials and civil liberty).

123. See infra text accompanying notes 158-161 (describing the data on women's political equality).

124. For example, the dispute over whether punishment inflicted pursuant to the Sharia constitutes "torture" in violation of the Torture Convention was resolved in this study in favor of the countries arguing that it does not constitute torture.

125. In coding the torture practices of countries, I considered only torture committed by agents of the state. Genocide is defined by the authors of the State Failure Problem Set from which I drew my data in part as "the promotion, execution, and/or implied consent of sustained policies by governing elites or their agents - or in the case of civil war, either of the contending authorities-that result in the deaths of a substantial portion of a communal group or politicized non-communal group." Ted Robert Gurr et al., Codebook: Internal Wars and Failures of Governance, 1954-1996, at 1 I (May 19, 1997) (unpublished manuscript, on file with author) (emphasis added). The Civil Liberty index also measures freedoms largely in the control of the state, such as free and independent media, free religious institutions, free public and private rcligious expression, freedom of assembly, freedom of political organization, free trade unions, and peasant organizations or the equivalent. $C f$. FREEDOM HOUSE, FREEDOM IN THE WORLD: THE ANNUAl SURVEY OF POLITICAL RIGHTS AND CIVIL LiBERTIES 1999-2000, at 584 (Adrian Karatnycky ed., 2000) (providing a civil liberties checklist). Finally, whether or not a state provides a fair and public trial is a matter largely within the hands of the state. These areas all contrast markedly with the examples of areas where the state "lacks capacity" cited by Chayes and Chayes, such as agreements to reduce environmental pollutants, which require the state to influence private behavior. See CHAYES \& CHAYES, supra note 1, at 13-15. 
coherence condition (like cases are treated alike) for legitimacy. By minimizing these obvious and widely accepted sources of noncompliance in the study, I can better focus attention on the central area of disagreement between normativists and rationalists, namely, whether and why nations comply (or do not comply) with clear, determinant, and coherent treaties to which they have some capacity to conform their actions.

I draw the measures of state practices in the five areas examined from four different sources: the Center for International Development and Conflict Management at the University of Maryland, College Park, the United States Department of State Country Reports on Human Rights, Freedom House's Annual Survey of Political Rights and Civil Liberties, and the Inter-Parliamentary Union. The database consists of 166 countries from 1960 to 1999 , for a total of 6474 separate observations. ${ }^{126}$ Because the database covers multiple countries over multiple years, I sometimes refer to a single observation as a "country-year," though for ease of reference I usually employ the less precise term "country."

None of the sources I use provides a perfect measure of countries' compliance with the requirements of a given treaty. Some of the measures are better than others, but each has its flaws. Indeed, an examination of the four sources demonstrates a tradeoff between the objectivity of the data sources and the level of tailoring of the sources to the relevant treaties. For example, I draw the data on torture and fair trials from the State Department reports. ${ }^{127}$ The strength of these data is the close tailoring of the data to the requirements of the treaties, which was possible because I coded the data in the State Department's narrative accounts with direct reference to the requirements of the relevant treaties. The primary weakness is the susceptibility of the State Department reports to charges of political bias. ${ }^{128}$ The data on genocide are drawn from an independent organization not known for particular biases. ${ }^{129}$ Yet the fit between the definition of genocide used in constructing the data and the very narrow definition of genocide in the Genocide Convention is imperfect. Similarly, the data on the percentage of men in parliament have the advantage of being entirely objective, yet again the fit between the data and the requirements of the treaty is imperfect.

While the problems of objectivity and fit ought not be ignored, they also ought not be overstated. Studies of the State Department Country

126. A list of the 166 states included in the database (one of which is the United States) appears in Appendix C. Notably, none of the analyses takes advantage of the full database, as there are significant gaps in the data for many of the variables, and an entire observation is dropped whenever any portion of the data is missing. Nonetheless, with the exception of the analyses of the regional treaties, most of the analyses are based on well over 1000 observations.

127. See infra notes 137-151 and accompanying text.

128. See supra note 114 .

129. See infra note 132 and accompanying text. 
Reports on Human Rights have shown that their assessments of the human rights practices of countries differ only marginally from the assessments of Amnesty International, particularly after 1985, the period for which I use the State Department data. ${ }^{130}$ And where the fit between measures of country practices and treaty requirements is imperfect, the measures chosen are nonetheless strongly indicative of the success of countries in putting in place practices and institutions designed to achieve the requirements of the treaties. Moreover, it is imperative to note that I base each broad analytical conclusion on data drawn from at least two different data sources and do not rely on any empirical result that cannot be cross-validated. This approach mirrors that of the only other extant quantitative study of the relationship between human rights treaty ratification and country human rights practices. ${ }^{131}$

To give a more precise picture of the sources and definitions of the five areas under study, I discuss each in turn below.

\section{Genocide}

I obtained the data on genocide from the Center for International Development and Conflict Management at the University of Maryland, College Park. ${ }^{132}$ The Center defines "geno/politicide" as

the promotion, execution, and/or implied consent of sustained policies by governing elites or their agents - or in the case of civil war, either of the contending authorities-that result in the deaths of a substantial portion of a communal group or politicized

130. E.g., Steven C. Poe \& C. Neal Tate, Repression of Human Rights to Personal Integrity in the 1980s: A Global Analysis, 88 AM. POL. SCI. REV. 853, 855 (1994) ("Because of the rather high correlation between the two measures in our sample [i.e., the Amnesty International reports and the State Department reports] (zero-order correlation $=0.83$ ), we instead chose to substitute the value coded for the State Department scale when profile information was unavailable on a country in the Amnesty International reports and vice versa (in the few cases where it was necessary) as the best available approximation of those scores."); id. at 862 (displaying a graph that shows increasing convergence between the data derived from the State Department reports and the data from the Amnesty International reports over time, with no more than an approximate 0.1 -point difference in mean index on a scale of 1 to 5 between the two measures after 1985).

131. Keith, supra note 2 . Keith states:

For this study, the perfect measure of human rights behavior might include an indicator of each right that is protected in this treaty... . It would be extremely difficult to gather data that could adequately measure each of these rights. However, political scientists have developed two standards-based indices that are believed to be an acceptable measure for this study: the Freedom House Political and Civil Rights indices and Stohl et al.'s Personal Integrity measure [referred to here as the "Purdue Political Terror Scale," see infra note 170]. Using both of these sets of measures to test my hypothesis will allow for cross-validation.

Id. at 101 (citations omitted).

132. Ted Robert Gurr et al., Internal Wars and Failures of Governance, 1954-1996 (May 19, 1997) (unpublished data, on file with author). 
noncommunal group. In genocides the victimized groups are defined primarily in terms of their communal (ethnolinguistic, religious) characteristics. In politicides, by contrast, groups are defined primarily in terms of their political opposition to the regime and dominant groups.... In the case of geno/politicide authorities physically exterminate enough (not necessarily all) members of a target group so that it can no longer pose any conceivable threat to their rule or interests. ${ }^{133}$

In operationalizing the criteria, the Center provides: "(1) Authorities' complicity in mass murder must be established.... (2) The physical destruction of a people requires time to accomplish: it implies a persistent, coherent pattern of action.... (3) The victims to be counted are unarmed civilians, not combatants." ${ }^{134}$ The Center records the magnitude of each genocidal episode based on the annual number of deaths, placed on a scale that ranges from 0 to $5 .{ }^{135}$ With the exception of its inclusion of politicides (admittedly a substantial difference), the definition reasonably closely matches the definition of genocide offered in the Genocide Convention:

[G]enocide means any of the following acts committed with intent to destroy, in whole or in part, a national, ethnical, racial or religious group, as such: (a) Killing members of the group; (b) Causing serious bodily harm or mental harm to members of the group; (c) Deliberately inflicting on the group conditions of life calculated to bring about its physical destruction in whole or in part; (d) Imposing measures intended to prevent births within the group; (e) Forcibly transferring children of the group to another group. ${ }^{136}$

\section{Torture}

I generated the data on torture by coding the sections on torture in the United States Department of State Country Reports on Human Rights. The Torture index, which I constructed by referring directly to the requirements of the relevant treaties, ${ }^{137}$ ranges from 1 to 5 . In arraying countries'

133. Gurr et al., supra note 125 , at 11 .

134. Id.

135. The scale is as follows: $0=$ less than 300 annual deaths; $0.5=300-1000 ; 1.0=1000$ $2000 ; 1.5=2000-4000 ; 2.0=4000-8000 ; 2.5=8000-16,000 ; 3.0=16,000-32,000 ; 3.5=32,000$ 64,$000 ; 4.0=64,000-128,000 ; 4.5=128,000-256,000 ; 5.0=256,000$ or more. See id. at 12 .

136. Genocide Convention, supra note 121, art. 2, S. EXEC. DOC. O, 81-1, at 7, 78 U.N.T.S. at 280 .

137. The Torture Convention defines torture as

any act by which severe pain or suffering, whether physical or mental, is intentionally inflicted on a person for such purposes as obtaining from him or a third person information or a confession, punishing him for an act he or a third person has committed or is suspected of having committed, or intimidating or coercing him or a 
practices on this scale, I considered "beatings," which were frequently mentioned separately from "torture," to be a subcategory of torture when they constituted affirmative acts of physical or mental abuse in prison or by police or other governmental officials. In this subcategory, I included maltreatment used to extract confessions or in initial interrogations. I disregarded punishments carried out pursuant to a country's legal system, even if that system may be considered by some to sanction torture. Hence, I did not consider punishment carried out pursuant to the Sharia to constitute torture. When possible, I coded a country's practices using key words identified in the reports to indicate the frequency of the use of torture. I did not code widespread poor prison conditions (e.g., overcrowding, inadequate food, lengthy detentions prior to trial) as torture unless the conditions of detention were so severe as to constitute mistreatment or abuse aimed at intimidating, penalizing, or obtaining a confession from detainees. I gave weight to all information reported unless it was specifically noted to be likely untrue. In assigning a rating to a country, I gave the highest category to which it corresponded. Hence, if there were reports of "widespread torture" but no "beatings," the country-year would nonetheless be assigned a 5 . I rated country practices as described below:

1: There are no allegations or instances of torture in this year. There are no allegations or instances of beatings in this year; or there are only isolated reports of beatings by individual police officers or guards all of whom were disciplined when caught.

third person, or for any reason based on discrimination of any kind, when such pain or suffering is inflicted by or at the instigation of or with the acquiescence of a public official or other person acting in an official capacity. It does not include pain or suffering arising from, or inherent in or incidental to, lawful sanctions.

Torture Convention, supra note 51, art. 1, S. TREATY DoC. No. 100-20, at 19, 1465 U.N.T.S. at 113-14. The American Torture Convention defines torture as

any act intentionally performed whereby physical or mental pain or suffering is inflicted on a person for purposes of criminal investigation, as a means of intimidation, as personal punishment, as a preventive measure, as a penalty, or for any other purpose. Torture shall also be understood to be the use of methods upon a person intended to obliterate the personality of the victim or to diminish his physical or mental capacities, even if they do not cause physical pain or mental anguish.

The concept of torture shall not include physical or mental pain or suffering that is inherent in or solely the consequence of lawful measures, provided that they do not include the performance of the acts or use of the methods referred to in this article.

Inter-American Convention To Prevent and Punish Torture, adopted Dec. 9, 1985, art. 2, 25 I.L.M. 519, 521 (entered into force Feb. 28, 1987) [hereinafter American Torture Convention]; see also European Convention for the Prevention of Torture and Inhuman or Degrading Treatment or Punishment, opened for signature Nov. 26, 1987, pmbl., Europ. T.S. No. 126, at 2, 27 I.L.M. 1152, 1154 (entered into force Jan. 2, 1989) [hereinafter European Torture Convention] (prohibiting, but not defining, torturc); African Charter on Human and Peoples' Rights, adopted June 27, 1981, an. 5, 21 I.L.M. 58, 60 (entered into force Oct. 21, 1986) [hereinafter African Charter on Human Rights] (same). 
2: At least one of the following is true: There are only unsubstantiated and likely untrue allegations of torture; there are "isolated" instances of torture for which the government has provided redress; there are allegations or indications of beatings, mistreatment or harsh/rough treatment; there are some incidents of abuse of prisoners or detainees; or abuse or rough treatment occurs "sometimes" or "occasionally." Any reported beatings put a country into at least this category regardless of government systems in place to provide redress (except in the limited circumstances noted above).

3: At least one of the following is true: There are "some" or "occasional" allegations or incidents of torture (even "isolated" incidents unless they have been redressed or are unsubstantiated (see above)); there are "reports," "allegations," or "cases" of torture without reference to frequency; beatings are "common" (or "not uncommon"); there are "isolated" incidents of beatings to death or summary executions (this includes unexplained deaths suspected to be attributed to brutality) or there are beatings to death or summary executions without reference to frequency; there is severe maltreatment of prisoners; there are "numerous" reports of beatings; persons are "often" subjected to beatings; there is "regular" brutality; or psychological punishment is used.

4: At least one of the following is true: Torture is "common"; there are "several" reports of torture; there are "many" or "numerous" allegations of torture; torture is "practiced" (without reference to frequency); there is government apathy or ineffective prevention of torture; psychological punishment is "frequently" or "often" used; there are "frequent" beatings or rough handling; mistreatment or beating is "routine"; there are "some" or "occasional" incidents of beatings to death; or there are "several" reports of beatings to death.

5: At least one of the following is true: Torture is "prevalent" or "widespread"; there is "repeated" and "methodical" torture; there are "many" incidents of torture; torture is "routine" or standard practice; torture is "frequent"; there are "common," "frequent," or "many" beatings to death or summary executions; or there are "widespread" beatings to death.

A researcher working under my guidance performed the initial coding. A second researcher then coded a random sample of $20 \%$ of the data to test reproducibility reliability. ${ }^{138}$ Intercoder reliability, which I assessed using

138. "Reproducibility reliability is the extent to which coding decisions can be replicated by different researchers." Stephen Lacy \& Daniel Riffe, Sampling Error and Selecting Intercoder 
Cohen's Kappa statistic, ${ }^{139}$ was $80 \%$. Because the information in the reports is scarce prior to 1985 , I deemed it insufficiently reliable and therefore included only data obtained from the reports from 1985 to 1998 in the data set, even though earlier reports are available. As with all of the human rights measures, where the data source does not cover a country or provides insufficient information on a country in a particular year to allow for coding, that entry is left blank in the database. As the United States is never covered by the State Department Country Reports on Human Rights, all the entries for the United States's torture practices are blank in the database. Because the United States is only one of 166 countries in the database, this omission ought not have a significant impact on the results. A complete copy of the data appears in Table $6 .{ }^{140}$

\section{Fair Trial}

I created the Fair Trial index by coding, with the help of two research assistants, the sections in the State Department Country Reports on Human Rights that addressed issues relating to fair trials. To code these sections, I identified ten elements of a paradigmatic fair trial by reference to the Covenant on Civil and Political Rights, the American Convention on Human Rights, the European Convention on Human Rights, and the African Charter on Human Rights. The identified elements of a fair trial include the following: an independent and impartial judiciary, ${ }^{141}$ the right to counsel, ${ }^{142}$ the right to present a defense, ${ }^{143}$ a presumption of innocence, ${ }^{144}$

Reliability Samples for Nominal Content Categories, 73 JOURNALISM \& MASS COMM. Q. 963 , 963 (1996).

139. Jean Carletta, Assessing Agreement on Classification Tasks: The Kappa Statistic, 22 COMPUTATIONAL LINGUISTICS 249, 252-53 (1996).

140. See infra Appendix C.

141. See African Charter on Human Rights, supra note 137, art. 26, 21 I.L.M. at 63 ("States parties to the present Charter shall have the duty to guarantee the independence of the Courts ...."); American Convention on Human Rights, opened for signature Nov. 22, 1969, art. $8, \S 1,1144$ U.N.T.S. 123, 147 (entered into force July 18, 1978) ("Every person has the right to a hearing, with due guarantees and within a reasonable time, by a competent, independent, and impartial tribunal, previously established by law ...."); Covenant on Civil and Political Rights, supra note 98, art. 14, S. EXEC. DOC. E, 95-2, at 25-26, 999 U.N.T.S. at 176-77 (" [E]veryone shall be entitled to a fair and public hearing by a competent, independent and impartial tribunal established by law."); European Convention on Human Rights, supra note 67, art. 6, § 1, 213 U.N.T.S. at 228 ("In the determination of his civil rights and obligations or of any criminal charge against him, everyone is entitled to a fair and public hearing within a reasonable time by an independent and impartial tribunal ....").

142. See African Charter on Human Rights, supra note 137, art. 7, 21 I.L.M. at 60 ("Every individual shall have the right to ... defence, including the right to be defended by counsel of his choice ...."); American Convention on Human Rights, supra note 141, art. 8, § 2, 1144 U.N.T.S. at 147 (" [E]very person is entitled, with full equality, to the following minimum guarantees: ... the right of the accused to ... be assisted by legal counsel of his own choosing, and to communicate freely and privately with his counsel; ... the inalienable right to be assisted by counsel provided by the State, paid or not as the domestic law provides, if the accused does not defend himself personally or engage his own counsel within the time period established by 
the right to appeal, ${ }^{145}$ the right to an interpreter, ${ }^{146}$ protection from ex post facto laws, ${ }^{147}$ a public trial, ${ }^{148}$ the right to have charges presented, ${ }^{149}$ and

law ... ."); Covenant on Civil and Political Rights, supra note 98, art. 14, § 3, S. ExEC. Doc. E, 95-2, at 26, 999 U.N.T.S. at 177 ("[E]veryone shall be entitled to . . defend himself in person or through legal assistance of his own choosing ...."); European Convention on Human Rights, supra note 67 , art. 6, \& 3, 213 U.N.T.S. at 228 ("Everyone charged with a criminal offence has the following minimum rights: ... to defend himself in person or through legal assistance of his own choosing or, if he has not sufficient means to pay for legal assistance, to be given it free when the interests of justice so require.").

143. See African Charter on Human Rights, supra note 137, art. 7,21 I.L.M. at 60 ("Every individual shall have the right to... defence ...."); American Convention on Human Rights, supra note 141 , art. 8, $§ 2,1144$ U.N.T.S. at 147 ("[E]very person is entitled, with full equality, to the following minimum guarantees: ... [t]he right of the accused to defend himself personally or to be assisted by legal counsel of his own choosing ...."); Covenant on Civil and Political Rights, supra note 98, ar. 14, \& 3, S. EXEC. DOC. E, 95-2, at 26, 999 U.N.T.S. at 177 ("[E]veryone shall be entitled to ... defend himself in person or through legal assistance of his own choosing ...."); European Convention on Human Rights, supra note 67, art. 6, § 3, 213 U.N.T.S. at 228 "Everyone charged with a criminal offence has the following minimum rights: ... to defend himself in person or through legal assistance of his own choosing ....").

144. See African Charter on Human Rights, supra note 137, art. 7, 21 I.L.M. at 60 ("Every individual shall have the right to ... be presumed innocent until proved guilty ...."); American Convention on Human Rights, supra note 141, art. 8, \$2, 1144 U.N.T.S. at 147 ("Every person accused of a criminal offense has the right to be presumed innocent so long as his guilt has not been proven according to law."); Covenant on Civil and Political Rights, supra note 98, art. 14, § 2, S. EXEC. DoC. E, 95-2, at 26, 999 U.N.T.S. at 176 ("Everyone charged with a criminal of fence shall have the right to be presumed innocent until proved guilty according to law."); European Convention on Human Rights, supra note 67, art. 6, § 3, 213 U.N.T.S. at 228 ("Everyone charged with a criminal offence shall be presumed innocent until proved guilty according to law.").

145. See African Charter on Human Rights, supra note 137, art. 7, 21 I.L.M. at 60 ("Every individual shall have the right to ... an appeal to competent national organs...."); American Convention on Human Rights, supra note 141, art. 8, § 2, 1144 U.N.T.S. at 147 (“[E]very person is entitled, with full equality, to the following minimum guarantees: ... the right to appeal the judgment to a higher cour ...."); Covenamt on Civil and Political Rights, supra note 98, art. 14, § 2, S. EXEC. DoC. E, 95-2, at 26, 999 U.N.T.S. at 176 ("Everyone charged with a criminal offence shall have the right to be presumed innocent until proved guilty according to law.").

146. See American Convention on Human Rights, supra note 141, art. 8, \& 2, 1144 U.N.T.S. at 147 (" $[E]$ very person is entitled, with full equality, to the following minimum guarantees: . . . the right of the accused to be assisted without charge by a translator or interpreter, if he does not understand or does not speak the language of the tribunal or court ...."); Covenant on Civil and Political Rights, supra note 98, art. 14, § 3, S. EXEC. DOC. E, 95-2, at 26, 999 U.N.T.S. at 177 ("[E]veryone shall be entitled to... have the free assistance of an interpreter if he cannot understand or speak the language used in court."); European Convention on Human Rights, supra note 67 , art. 6, \& 3, 213 U.N.T.S. at 228 ("Everyone charged with a criminal offence has the following minimum rights: ... to have the free assistance of an interpreter if he cannot understand or speak the language used in court.").

147. See African Charter on Human Rights, supra note 137, art. 7, 21 I.L.M. at 60 ("No one may be condemned for an act or omission which did not constitute a legally punishable offence at the time it was committed. No penalty may be inflicted for an offence for which no provision was made at the time it was committed."); American Convention on Human Rights, supra note 141, art. 9, 1144 U.N.T.S. at 148 ("No one shall be convicted of any act or omjssion that did not constitute a criminal offense, under the applicable law, at the time it was committed."); Covenant on Civil and Political Rights, supra note 98, art. 15, S. ExEC. DOC. E, 95-2, at 27, 999 U.N.T.S. at 177 ("No one shall be held guilty of any criminal offence on account of any act or omission which did not constitute a criminal offence, under national or international law, at the time when it was committed."); European Convention on Human Rights, supra note 67, art. 7, 213 U.N.T.S. at 228 ("No one shall be held guilty of any criminal offence on account of any act or omission 
timeliness. ${ }^{150}$ We then coded each element by country and year for compliance, partial compliance, or noncompliance. After coding each element, we aggregated the individual results to obtain a final code on a four-point scale, with a lower index indicating better practices. Due to the volume of work and time involved in coding trial practices in this manner, I limited the scope of inquiry to every third year, beginning in 1985 and ending in 1997. While State Department reports covering fair trial practices are available in years prior to 1985 , they are of insufficient detail to compare reliably to reports in later years. Intercoder reliability across the entire Fair Trial index was $82 \%$. The data used to measure fair trials appear in Table $7 .{ }^{151}$

which did not constitute a criminal offence under national or international law at the time when it was committed.").

148. See American Convention on Human Rights, supra note 141, art. 8, \$ 5, 1144 U.N.T.S. at 147 ("Criminal proceedings shall be public, except insofar as may be necessary to protect the interests of justice."); Covenant on Civil and Political Rights, supra note 98, art. 14, § 1, S. EXEC. DOC. E, 95-2, at 25, 999 U.N.T.S. at 176 ("[E]veryone shall be entitled to a fair and public hearing by a competent, independent and impartial tribunal established by law."); European Convention on Human Rights, supra note 67, art. 6, 213 U.N.T.S. at 228 ("In the determination of his civil rights and obligations or of any criminal charge against him, everyone is entitled to a fair and public hearing within a reasonable time .... Judgment shall be pronounced publicly but the press and public may be excluded from all or part of the trial in the interests of morals, public order or national security in a democratic society, where the interests of juveniles or the protection of the private life of the parties so require, or to the extent strictly necessary in the opinion of the court in special circumstances where publicity would prejudice the interests of justice.").

149. See African Charter on Human Rights, supra note 137, art. 6, 21 I.L.M. at 60 ("No one may be deprived of his freedom except for reasons and conditions previously laid down by law. In particular, no one may be arbitrarily arrested or detained."); American Convention on Human Rights, supra note 141, art. 8, $\$ 2,1144$ U.N.T.S. at 147 (" [E]very person is entitled, with full equality, to the following minimum guarantees: ... prior notification in detail to the accused of the charges against him ..." ); Covenant on Civil and Political Rights, supra note 98, art. 14, § 3 , S. EXEC. Doc. E, 95-2, at 26, 999 U.N.T.S. at 177 (" [E]veryone shall be entitled to . . be informed promptly and in detail in a language which he understands of the nature and cause of the charge against him ...."); European Convention on Human Rights, supra note 67, art. 6, § 3, 213 U.N.T.S, at 228 ("Everyone charged with a criminal offence has the following minimum rights: ... to be informed promptly, in a language which he understands and in detail, of the nature and cause of the accusation against him.").

150. See African Charter on Human Rights, supra note 137, art. 7, 21 1.L.M. at 60 ("Every individual shall have the right ... to be tried within a reasonable time by an impartial court or tribunal...."); American Convention on Human Rights, supra note 141, art. 8, \& 2, 1144 U.N.T.S. at 147 (" $[E]$ very person is entitled, with full equality, to ... adequate time and means for the preparation of his defense ...."); Covenant on Civil and Political Rights, supra note 98, art. 14, \& 3, S. EXEC. DOC. E, 95-2, at 26, 999 U.N.T.S. at 177 ("[E]veryone shall be entitled... to be tried without undue delay...."); European Convention on Human Rights, supra note 67, art. 6, 213 U.N.T.S. at 228 (" $[E]$ veryone is entitled to a fair and public hearing within a reasonable time....").

151. See infra Appendix C. 


\section{Civil Liberty}

I draw the Civil Liberty variable from Freedom House's Comparative Survey of Freedom. ${ }^{152}$ It is reported on a 1 to 7 scale, with 1 being the best and 7 the worst. The scale is constructed from answers to a "Civil Liberties Checklist" that includes freedom of expression and belief, association and organizational rights, rule of law and human rights, and personal autonomy and economic rights. ${ }^{153}$ As broad as the civil liberties checklist is, it overlaps quite well with the equally broad treaties for which I use it as a measure of compliance. The Covenant on Civil and Political Rights protects freedom of expression and belief in Articles 18, 19, and 27; association and organizational rights in Articles 1, 18,21, and 22; rule of law and human rights in Articles 6, 7, 9, 14, 15, 16, 17, 25, and 26; and personal autonomy and economic rights in Articles 1, 3, 8, 12, 22, 23, and 25. ${ }^{154}$ The African Charter protects freedom of expression and belief in Articles 8 and 9; association and organizational rights in Articles 10,11, and 20; rule of law and human rights in Articles 3, 5, 6, 7, 23, and 26; and personal autonomy and economic rights in Articles 12,14, 18, 19, and 21. ${ }^{155}$ The American Convention on Human Rights protects freedom of expression and belief in Articles 12 and 13; association and organizational rights in Articles 15 and 16; rule of law and human rights in Articles 3, 5, 7, 8, 24, and 25; and personal autonomy and economic rights in Articles 1, 17, 21, and 22. ${ }^{156}$ Finally, the European Convention on Human Rights protects freedom of expression and belief in Articles 9 and 10; association and organizational rights in Article 11; rule of law and human rights in Articles 3, 5, and 6; and personal autonomy and economic rights in Articles 8, 12, and 14. ${ }^{157}$

\section{Women's Political Equality}

I measured women's political equality using the percentage of men in each country's legislature. ${ }^{158}$ The data are derived from data published by the Inter-Parliamentary Union. ${ }^{159}$ Although the Convention on the Political

152. For the set of ratings for the entire history of the Freedom in the World reports, see Freedom House, Country Ratings, at http://www.freedomhouse.org/ratings/index.htm (last modified May 8, 2001). Frecdom House graciously provided the ratings to me in a database format.

153. See FREEDOM HouSE, supra note 125, at 584-85.

154. Covenant on Civil and Political Rights, supra note 98.

155. African Charter on Human Rights, supra note 137.

156. American Convention on Human Rights, supra note 141.

157. European Convention on Human Rights, supra note 67.

158. Where a country's legislature is divided into two houses, I added the two houses together before calculating the percentage of men in the legislature.

159. INTER-PARLIAMENTARY UNION, WOMEN IN PARLIAMENTS 1945-1995: A WorLD STATISTICAL SURVEY (1995). 
Rights of Women of course does not require equal numbers of women and men to serve in a country's legislature, the preamble does provide:

The Contracting Parties... [r]ecogniz[e] that everyone has the right to take part in the government of his country, directly or indirectly through freely chosen representatives, and has the right to equal access to public service in his country, and desir[e] to equalize the status of men and women in the enjoyment and exercise of political rights, in accordance with the provisions of the Charter of the United Nations and the Universal Declaration of Human Rights .... ${ }^{160}$

Moreover, two of the three substantive articles in the treaty directly address women's participation in government. Articles II and III provide that "[w]omen shall be eligible for election to all publicly elected bodies, established by national law, on equal terms with men, without any discrimination," and that "[w]omen shall be entitled to hold public office and to exercise all public functions, established by national law, on equal terms with men, without any discrimination." 161 Consequently, a measure of women's direct political participation-which of course depends on women's access to direct participation in government-appears likely to be strongly correlated with country compliance with the treaty's goals.

\section{B. Do Countries Comply?}

This first portion of the quantitative analysis examines whether countries that ratify human rights treaties tend to conform their activity to the requirements of the treaties. I do not aim here to demonstrate any causal relationship between treaty ratification and country practices. Rather, my purpose in this portion of the analysis is simply to determine whether countries that have ratified human rights treaties are more likely to conform their conduct to the treaties than are countries that have not ratified the same treaties, regardless of the reasons for conformance. In short, I seek here only insight into whether countries that ratify these treaties have better human rights practices than those that do not.

An initial analysis of the relationship between treaty ratification and country ratings (as shown in Tables 1 and 2) indicates that, for the most part, countries that have ratified human rights treaties have better human rights ratings than those that have not. On this first test, therefore, the

160. Convention on the Political Rights of Women, opened for signature Mar. 31, 1953, pmbl., 27 U.S.T. 1909, 1911 , 193 U.N.T.S. 135, 136 (entered into force July 7, 1954).

161. Id. arts. II-III, 27 U.S.T. at 1911, 193 U.N.T.S. at 138. 
TABLE 1. HUMAN RIGHTS RATINGS: RATIFYING COUNTRY-YEARS VERSUS NONRATIFYING COUNTRY-YEARS (BETTER AVERAGES IN BOLD)

\begin{tabular}{|c|c|c|c|c|}
\hline Treaty & $\begin{array}{l}\text { Human } \\
\text { Rights Metric }\end{array}$ & $\begin{array}{l}\text { Average } \\
\text { Ratifying }\end{array}$ & $\begin{array}{c}\text { Average } \\
\text { Non- } \\
\text { ratifying }\end{array}$ & $\begin{array}{l}\text { Number of } \\
\text { Observations }\end{array}$ \\
\hline Genocide Convention & Genocide $^{a}$ & $\begin{array}{c}\mathbf{0 . 0 7 4} \\
(0.008)\end{array}$ & $\begin{array}{c}0.093 \\
(0.009)\end{array}$ & 6640 \\
\hline Torture Convention & Torture $^{\mathrm{b}}$ & $\begin{array}{c}\mathbf{2 . 7 0} \\
(0.042)\end{array}$ & $\begin{array}{c}2.76 \\
(0.030)\end{array}$ & 2228 \\
\hline Article 21 & Torture & $\begin{array}{r}2.06 \\
(0.058)\end{array}$ & $\begin{array}{c}2.85 \\
(0.025)\end{array}$ & 2223 \\
\hline $\begin{array}{l}\text { Covenant on Civil and } \\
\text { Political Rights }\end{array}$ & Fair Trial $^{\mathfrak{c}}$ & $\begin{array}{r}2.15 \\
(0.045) \\
\end{array}$ & $\begin{array}{c}2.42 \\
(0.056)\end{array}$ & 740 \\
\hline Optional Protocol & Fair Trial & $\begin{array}{r}1.98 \\
(0.062)\end{array}$ & $\begin{array}{c}2.39 \\
(0.041)\end{array}$ & 740 \\
\hline $\begin{array}{l}\text { Covenant on Civil and } \\
\text { Political Rights }\end{array}$ & Civil Liberty $^{\mathrm{d}}$ & $\begin{array}{c}3.77 \\
(0.045)\end{array}$ & $\begin{array}{c}4.66 \\
(0.038)\end{array}$ & 4076 \\
\hline Optional Protocol & Civil Liberty & $\begin{array}{c}2.94 \\
(0.054)\end{array}$ & $\begin{array}{c}4.65 \\
(0.033)\end{array}$ & 3996 \\
\hline $\begin{array}{l}\text { Conv. on the Political } \\
\text { Rights of Women }\end{array}$ & $\begin{array}{l}\text { Men in } \\
\text { Parliament }\end{array}$ & $\begin{array}{c}0.91 \\
(0.002)\end{array}$ & $\begin{array}{c}0.93 \\
(0.002)\end{array}$ & 3990 \\
\hline $\begin{array}{l}\text { American Torture } \\
\text { Convention }\end{array}$ & Torture & $\begin{array}{r}3.26 \\
(0.093)\end{array}$ & $\begin{array}{c}2.96 \\
(0.068)\end{array}$ & 332 \\
\hline $\begin{array}{l}\text { African Charter on } \\
\text { Human Rights }\end{array}$ & Torture & $\begin{array}{r}2.99 \\
(0.042) \\
\end{array}$ & $\begin{array}{c}2.65 \\
(0.071) \\
\end{array}$ & 703 \\
\hline $\begin{array}{l}\text { European Torture } \\
\text { Convention }\end{array}$ & Torture & $\begin{array}{r}1.86 \\
(0.060) \\
\end{array}$ & $\begin{array}{c}1.67 \\
(0.079) \\
\end{array}$ & 379 \\
\hline $\begin{array}{l}\text { American Convention on } \\
\text { Human Rights }\end{array}$ & Fair Trial & $\begin{array}{c}2.66 \\
(0.088)\end{array}$ & $\begin{array}{c}2.33 \\
(0.237)\end{array}$ & 110 \\
\hline $\begin{array}{l}\text { African Charter on } \\
\text { Human Rights }\end{array}$ & Fair Trial & $\begin{array}{r}2.45 \\
(0.066)\end{array}$ & $\begin{array}{c}2.24 \\
(0.114)\end{array}$ & 234 \\
\hline $\begin{array}{l}\text { European Convention on } \\
\text { Human Rights }\end{array}$ & Fair Trial & $\begin{array}{r}1.23 \\
(0.056)\end{array}$ & $\begin{array}{c}1.36 \\
(0.091)\end{array}$ & 126 \\
\hline $\begin{array}{l}\text { American Convention on } \\
\text { Human Rights }\end{array}$ & Civil Liberty & $\begin{array}{c}3.22 \\
(0.061)\end{array}$ & $\begin{array}{c}3.80 \\
(0.115)\end{array}$ & 633 \\
\hline $\begin{array}{l}\text { African Charter on } \\
\text { Human Rights }\end{array}$ & Civil Liberty & $\begin{array}{r}4.95 \\
(0.058)\end{array}$ & $\begin{array}{c}5.36 \\
(0.049)\end{array}$ & 1271 \\
\hline $\begin{array}{l}\text { European Convention on } \\
\text { Human Rights }\end{array}$ & Civil Liberty & $\begin{aligned} 1.63 \\
(0.041)\end{aligned}$ & $\begin{array}{c}3.34 \\
(0.252)\end{array}$ & 630 \\
\hline
\end{tabular}

${ }^{a}$ Genocide is measured from 0 (no genocide) to 5 (rampant genocide).

b Torture is measured from 1 (little or no torture) to 5 (rampant torture).

${ }^{c}$ Fair Trial is measured from 1 (fair) to 4 (not fair).

d Civil Liberty is rated from 1(high liberty) to 8 (low liberty).

'Men in Parliament is the fraction of the country's legislature that are men.

Note: For all of the human rights measures a lower index indicates better practices. Standard deviations in the data appear in parentheses. 
record appears to validate the contention of normative theory that countries are likely to comply with their international legal commitments. Probing slightly deeper, however, I find reason to question these optimistic results. Although countries that have ratified treaties have better human rights ratings on average, I find that not only does noncompliance seem to be rampant-a finding that would be consistent with some of the rational actor models identified above-but countries with poor human rights ratings are sometimes more likely to have ratified the relevant treaties than are countries with better ratings, a finding that is largely unexplained by either the normative or the rationalist theories.

As Table 1 shows, a comparison of the human rights ratings for country-years (referred to below for ease of reference as "countries") in which human rights treaties have been ratified with those in which they have not reveals that ratifiers generally have better average human rights ratings than nonratifiers (the better averages are in bold). This is true for all the universal human rights treaties examined. Countries that have ratified the Covenant on Civil and Political Rights ${ }^{162}$ appear to have better average civil liberties and fairer trials, with average ratings of roughly a full point and a third of a point lower than for nonratifiers, respectively. The same is true of those that have ratified the Optional Protocol to that Covenant; ${ }^{163}$ indeed the difference between ratings of ratifiers and nonratifiers is greater. Countries that have ratified the Convention on the Political Rights of Women ${ }^{164}$ have an average of $91 \%$ of their legislature made up of men, compared to an average of $93 \%$ for nonratifying countries.

For the Torture Convention, the differences in average level of human rights ratings for ratifiers versus nonratifiers are small. Countries that have ratified the Convention have an average Torture index of 2.70 , compared to 2.76 for nonratifiers; countries that have ratified Article $21^{165}$ to that Convention (which provides for state-to-state complaints) have an average Torture index of 2.06 compared to 2.85 for nonratifiers. (The results for this analysis and all others of Article 21 described in this Article are nearly identical to those for Article $22^{166}$ to that Convention, which provides for individual complaints, because forty-two of the forty-five countries that have accepted Article 21 accepted Article 22 in the same year.) The Genocide Convention likewise exhibits a small difference between means: 0.074 for ratifying countries, which is marginally better than the 0.093 for nonratifying countries.

162. Covenant on Civil and Political Rights, supra note 98.

163. Optional Protocol to the International Covenant on Civil and Political Rights, adopted Dec. 19, 1966, 999 U.N.T.S. 302 [hereinafter Optional Protocol].

164. Convention on the Political Rights of Women, supra note 160.

165. Torture Convention, supra note 51, art. 21 , S. TREATY DOC. NO. 100-20, at 26-27, 1465 U.N.T.S. at $118-20$.

166. Id. art. 22, S. TREATY Doc. No. 100-20, at 27-28, 1465 U.N.T.S. at 120. 
The finding that countries that ratify human rights treaties have better ratings than those that do not is not universal. Indeed, the regional treaties that outlaw torture ${ }^{167}$ show the opposite result: The countries that have ratified the treaties appear to have worse torture practices than the countries that are members of the sponsoring regional organization but have not ratified the treaties, ${ }^{168}$ and the differences are particularly striking for the American Torture Convention and for the African Charter. The same is true of the American and African regional treaties requiring fair and public trials: Countries that have ratified the treaties have worse ratings on average than countries that are members of the sponsoring regional organization but have not ratified the treaties. ${ }^{169}$ I arrive at similar results using an independent measure of repression. ${ }^{170}$ Moreover, even where the ratings of ratifiers are better than those of nonratifiers, the differences are not as large as one might expect.

Table 2 shows the results of a similar analysis performed on fully democratic countries (defined as those with democracy ratings of 10 on a scale of 1 to 10). ${ }^{171}$ The data indicate that fully democratic countries exhibit similar patterns of compliance to the group of nations as a whole, perhaps calling into question some liberals' predictions that democratic countries will be more likely to comply with their international legal commitments than nondemocracies. ${ }^{172}$ Although the human rights ratings of full

167. For the regional torture conventions, I use the European Torture Convention and the American Torture Convention rather than the European Convention on Human Rights and American Convention on Human Rights (both of which also prohibit torture) because the more particularized treaties give specific content to the torture prohibition and put in place mechanisms to make the prohibition on torture more effective.

168. Although today all the members of the Council of Europe have ratified the European Convention on Human Rights, this has not always been true. Until ratification of the Convention was made an effective condition of membership, most countries took several years or more to ratify the Convention after joining the Council. Because the data set is a time series, this is the basis for the comparison of ratifying country-years (again, referred to here with the shorthand "countries") versus nonratifying country-years in the European context.

169. The treaties specifically require the elements of fair and public trials measured by the Fair Trial index. For more on the index, see supra notes 141-151 and accompanying text.

170. I obtain nearly identical results using the Purdue Political Terror Scale (PTS), a measure of political repression put together by researchers at Purdue University based on the United States Department of State reports and the Amnesty International annual reports on country human rights practices. See Michael Stohl, Purdue University Political Terror Scale, at http://www.ippu.purdue.edu/info/gsp/govem.htm (last visited Jan. 29, 2002). Using this measure, I find that countries that ratify the African Charter on Human Rights have an average PTS (State) index of 2.89 versus 2.50 for nonratifiers (on a scale of 1 to 5 , where lower is better), and an average PTS (Amnesty) index of 2.96 versus 2.73 for nonratifiers. Similarly, I find that countries that have ratified the European Torture Convention have an average PTS (State) index of 1.67 versus 1.47 for nonratifiers, and an average PTS (Amnesty) index of 2.32 versus 1.61 for nonratifiers.

171. Countries with a democracy rating of 10 make up roughly $18 \%$ of the entire sample. For more on the democracy scale, see infra Appendix B, Section G.

172. See supra text accompanying notes 61-65. 
TABLE 2. HUMAN RIGHTS RATINGS OF FULL DEMOCRACIES: RATIFYING COUNTRY-YEARS VERSUS NONRATIFYING COUNTRY-YEARS (BETTER AVERAGES IN BOLD)

\begin{tabular}{|c|c|c|c|c|}
\hline Treaty & $\begin{array}{l}\text { Human } \\
\text { Rights Metric }\end{array}$ & $\begin{array}{l}\text { Average } \\
\text { Ratifying }\end{array}$ & $\begin{array}{c}\text { Average } \\
\text { Non- } \\
\text { ratifying }\end{array}$ & $\begin{array}{l}\text { Number of } \\
\text { Observations }\end{array}$ \\
\hline Genocide Convention & Genocide & - & - & 0 \\
\hline Torture Convention & Torture & $\begin{array}{r}1.66 \\
(0.044) \\
\end{array}$ & $\begin{array}{r}1.58 \\
(0.062) \\
\end{array}$ & 429 \\
\hline Article 21 & Torture & $\begin{array}{c}1.59 \\
(0.048) \\
\end{array}$ & $\begin{array}{c}1.67 \\
(0.056) \\
\end{array}$ & 424 \\
\hline $\begin{array}{l}\text { Covenant on Civil and } \\
\text { Political Rights }\end{array}$ & Fair Trial & $\begin{array}{c}1.12 \\
(0.032) \\
\end{array}$ & $\begin{array}{c}1.35 \\
(0.143) \\
\end{array}$ & 141 \\
\hline Optional Protocol & Fair Trial & $\begin{array}{c}1.16 \\
(0.041) \\
\end{array}$ & $\begin{array}{r}1.14 \\
(0.064) \\
\end{array}$ & 139 \\
\hline $\begin{array}{l}\text { Covenant on Civil and } \\
\text { Political Rights }\end{array}$ & Civil Liberty & $\begin{array}{c}1.42 \\
(0.027)\end{array}$ & $\begin{array}{c}1.42 \\
(0.048)\end{array}$ & 749 \\
\hline Optional Protocol & Civil Liberty & $\begin{array}{r}1.41 \\
(0.029) \\
\end{array}$ & $\begin{array}{c}1.43 \\
(0.040) \\
\end{array}$ & 731 \\
\hline $\begin{array}{l}\text { Conv. on the Political } \\
\text { Rights of Women }\end{array}$ & $\begin{array}{l}\text { Men in } \\
\text { Parliament }\end{array}$ & $\begin{array}{r}0.89 \\
(0.004) \\
\end{array}$ & $\begin{array}{c}0.94 \\
(0.002) \\
\end{array}$ & 865 \\
\hline $\begin{array}{l}\text { American Torture } \\
\text { Convention }\end{array}$ & Torture & $\begin{array}{c}2.33 \\
(0.194) \\
\end{array}$ & $\begin{array}{r}1.97 \\
(0.151) \\
\end{array}$ & 42 \\
\hline $\begin{array}{l}\text { African Charter on } \\
\text { Human Rights } \\
\end{array}$ & Torture & $\begin{array}{c}2.14 \\
(0.137) \\
\end{array}$ & $\begin{array}{r}1.38 \\
(0.177) \\
\end{array}$ & 15 \\
\hline $\begin{array}{l}\text { European Torture } \\
\text { Convention } \\
\end{array}$ & Torture & $\begin{array}{c}1.59 \\
(0.049) \\
\end{array}$ & $\begin{array}{r}1.42 \\
(0.066) \\
\end{array}$ & 289 \\
\hline $\begin{array}{l}\text { American Convention on } \\
\text { Human Rights }\end{array}$ & Fair Trial & $\begin{array}{c}1.45 \\
(0.205)\end{array}$ & $\begin{array}{r}1.00 \\
(0)\end{array}$ & 14 \\
\hline $\begin{array}{l}\text { African Charter on } \\
\text { Human Rights } \\
\end{array}$ & Fair Trial & $\begin{array}{c}1.00 \\
(0)\end{array}$ & $\begin{array}{c}1.33 \\
(0.304) \\
\end{array}$ & 5 \\
\hline $\begin{array}{l}\text { European Convention on } \\
\text { Human Rights }\end{array}$ & Fair Trial & $\begin{array}{r}1.15 \\
(0.041) \\
\end{array}$ & $\begin{array}{r}1.00 \\
(0) \\
\end{array}$ & 96 \\
\hline $\begin{array}{l}\text { American Convention on } \\
\text { Human Rights }\end{array}$ & Civil Liberty & $\begin{array}{r}1.75 \\
(0.098) \\
\end{array}$ & $\begin{array}{r}1.23 \\
(0.085) \\
\end{array}$ & 96 \\
\hline $\begin{array}{l}\text { African Charter on } \\
\text { Human Rights }\end{array}$ & Civil Liberty & $\begin{array}{r}2.00 \\
(0)\end{array}$ & $\begin{array}{r}2.00 \\
(0)\end{array}$ & 18 \\
\hline $\begin{array}{l}\text { European Convention on } \\
\text { Human Rights }\end{array}$ & Civil Liberty & $\begin{array}{r}1.32 \\
(0.027) \\
\end{array}$ & $\begin{array}{c}1.63 \\
(0.107) \\
\end{array}$ & 475 \\
\hline
\end{tabular}

Note: For all of the human rights measures a lower index indicates better practices. Standard deviations in the data appear in parentheses.

democracies are usually better, the relationship between treaty ratification and human rights ratings is very similar. Fully democratic countries that have ratified the universal human rights treaties usually have better human rights ratings, on average, than those that have not. As with the group of nations as a whole, however, this pattern does not hold for regional treaties. In six out of nine cases, ratification of regional treaties is associated with 
worse, rather than better, ratings. ${ }^{173}$ Similarly and somewhat more surprisingly, expanding the group of democratic countries examined to include those with democracy ratings of 6 or above suggests that democratic countries that ratify the Genocide Convention and the Optional Protocol (with regard to Civil Liberty) have worse practices than those that do not. ${ }^{174}$ Thus, democratic countries appear to be no more likely to have better human rights practices when they have ratified treaties than the group of countries as a whole.

When we look at human rights treaty compliance from a slightly different perspective, however, a somewhat more pessimistic picture emerges. Figures 1 through 5 map treaty ratification rates for each human rights measure. For each treaty, I calculated and plotted the mean level of ratification of the group of countries at each level of the relevant human rights measure. ${ }^{175}$ The graphical picture that emerges indicates that the countries with the worst human rights ratings are sometimes as likely as those with the best ratings to have joined the relevant human rights treaties. Many countries that ratify human rights treaties, it appears, regularly and predictably violate their voluntarily assumed human rights treaty obligations.

Although the figures show a consistently high level of noncompliance, their patterns vary. Figure 1 shows that approximately $50 \%$ of countries where no acts of genocide are recorded have ratified the Genocide

173. Unlike the group of nations as a whole, fully democratic countries that ratify the American Convention on Human Rights have worse Civil Liberty ratings on average than those that do not. And, unlike the group of nations as a whole, fully democratic nations that ratify the African Charter on Human Rights have better average Fair Trial ratings than those that do not ratify. This mean is based, however, on a population size of only five. Moreover, when the group of democratic countries is enlarged to include countries with a democracy rating of 6 or above, the mean Fair Trial rating of ratifying countries for the African Charter is worse than that of nonratifying countries. (There are thirty-seven observations involving countries in the OAU with a democracy rating of 6 or above.) The mean level of the Fair Trial measure for countries ratifying the African Charter on Human Rights is 2, versus a level of 1.5 for nonratifying countries.

174. Thirty-six percent of the entire data set has a democracy rating of 6 or greater. In the case of the Genocide Convention, the average level of Genocide if the treaty is ratified is 0.016 , compared to 0.014 if it is not, for the 3077 observations in the database. In the case of the Optional Protocol, the average Civil Liberty rating if the treaty is ratified is 2.52 , compared to 2.10 if it is not, for the 1576 observations in the database.

175. For instance, for genocide, which is measured on a scale from 0 to 5 , I determined the mean level of ratification of the Genocide Convention for countries with a level 0 Genocide, a level 0.5 Genocide, a level 1 Genocide, and so on, and plotted them on the graph in Figure 1. Because the data cover nearly forty years (all of which post-date the entry into force of the Genocide Convention), each country is included multiple times in the data from which I generated the graph. Hence, the figures are not a point-in-time record of the relationship between human rights practices and ratification of the relevant treaty; rather, they reflect the relationship over the thirty-nine years covered by the data. I calculated ratification rates for the regional treaties using a subset of the database that included only countries that are eligible to join the relevant treaty. Hence, I limited the database to members of the Organization of American States for the American treaties, members of the Organization of African Unity for the African treaties, and members of the Council of Europe for the European treaties. 
Convention, rising to $85 \%$ of countries reported to have committed an average of 1000 to 2000 acts of genocide (a 1 on the Internal Wars and Failures of Governance scale), falling to a low of less than $10 \%$ of countries reported to have committed 16,000 to 32,000 acts of genocide (a 3 on the scale), and rising again to a high of $47 \%$ of countries reported to have committed an average of 64,000 to 128,000 acts of genocide (a 4 on the scale). ${ }^{176}$ In other words, countries with the worst Genocide ratings are just about as likely as those with the best to have ratified the Genocide Convention. For this Convention, it is impossible to test the liberalist prediction that full democracies are more likely to comply with human rights treaty requirements than others, as no country classified as a full democracy was found to have committed any genocide. ${ }^{177}$

\section{FiguRE 1. GENOCIDE}

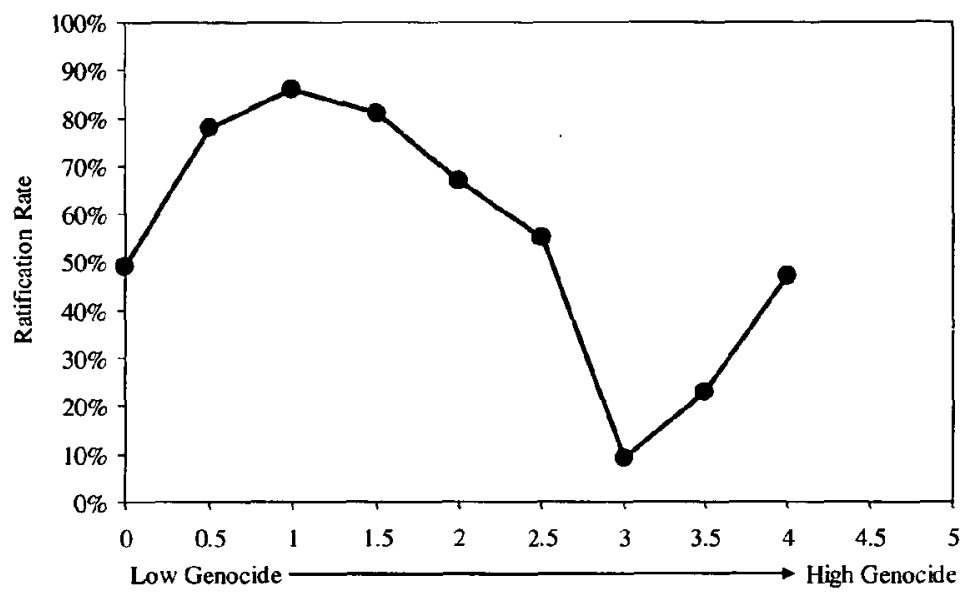

-Genocide Convention

The relationship between country Torture ratings and ratification of the various treaties outlawing torture exhibits a similar pattern to that found

176. I omitted data points that relied on fewer than fifteen observations. For instance, fewer than fifteen country-years registered as a 4.5 or 5 on the Genocide scale.

177. Such countries ratified the Genocide Convention at an average rate of $40 \%$. Countries with democracy ratings of 6 to 10 and with a Genocide rating of 0 ratified the Genocide Convention at an average rate of $49 \%$. Although some of these countries received slightly higher Genocide ratings, not enough of these met the fifteen-observation minimum, and I therefore omitted these data from the graph. See supra note 176. 
between treaty ratification and human rights ratings in the area of genocide. Figure 2 shows that the level of ratification of the universal Torture Convention has a relatively flat relationship to recorded levels of torture, with a gradual decline in the ratification rate as recorded torture levels rise and a small rise in the ratification rate as recorded torture levels reach their highest point. The results for the regional treaties are more interesting. As a whole, they exhibit a pattern that is inconsistent with normative and institutional theories, with ratification rates rising or remaining almost flat as Torture ratings worsen. On the other hand, Article 21 of the Torture Convention, which authorizes state parties to file complaints against states that have opted into the provision, exhibits a gradual and consistent downward trend-that is, countries with worse ratings are less likely to ratify. ${ }^{178}$

Plotting the relationship between human rights ratings and ratification of the Torture Convention by full democracies, I again find an upward slope at the start of the curve. Countries that appear the least likely to torture have a ratification rate of $51 \%$. This rises initially to $73 \%$ for countries that register as a 2 on the 5-point Torture scale, and then falls back to $51 \%$ for countries with a Torture rating of 3 . No full democracy warranted a Torture rating of 4 or $5 .{ }^{179} \mathrm{I}$ find a similar pattern for Article 21 . 170.

178. Again, I reach similar results using the Purdue Political Terror Scales. See supra note

179. Although I do not include these results in the figure below, it is interesting to note that for this figure, as for all those that follow, when the group of democratic countries examined is expanded to include countries with democracy ratings of 6 or above, the results are very similar to those for the entire data set, though the ratification rates at each level of Torture tend to be slightly higher over most of the graph. For the Torture Convention, the ratification rates for countries with democracy ratings of 6 to 10 is $49 \%$ for those with Torture ratings of $1,60 \%$ for those with ratings of $2,47 \%$ for those with ratings of $3,40 \%$ for those with ratings of 4 , and $51 \%$ for those with ratings of 5 . For Article 21, the ratification rates are $42 \%$ for those with ratings of $1,33 \%$ for those with ratings of $2,18 \%$ for those with ratings of $3,8 \%$ for those with ratings of 4 , and $2 \%$ for those with ratings of 5 . For the ratification rates for the other conventions for countries with democracy ratings of 6 to 10 , see infra notes 180-182. 


\section{FIGURE 2. TORTURE}

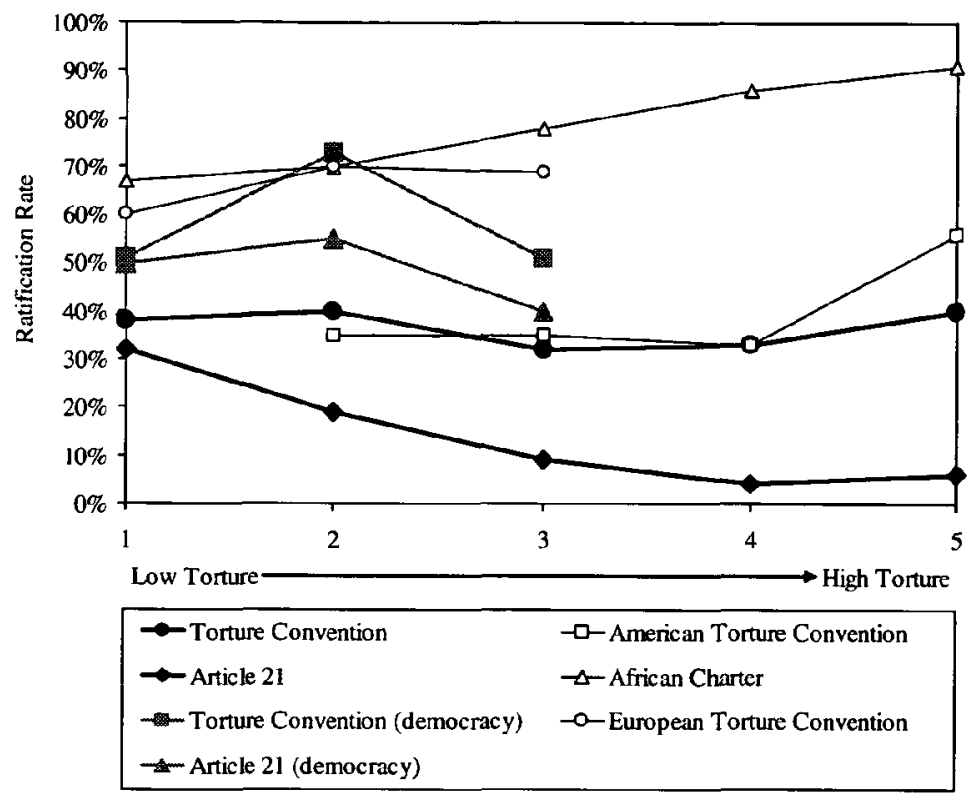

In some contrast with the results summarized in the figures above, ratification rates for treaties requiring fair and public trials are largely flat across the spectrum of fair trial levels, as Figure 3 shows. In some casesthe Covenant on Civil and Political Rights, the Optional Protocol, and the European Convention on Human Rights-ratification rates fall very gradually, varying by less than thirty percentage points across the full spectrum of Fair Trial ratings. The ratification rates for the American Convention on Human Rights and the African Charter on Human Rights rise by an equally small amount, again varying less than twenty-five percentage points across the entire graph. The ratification rates for the fully democratic countries fall somewhat more steeply than the others between the Fair Trial codes of 1 and 2, the only two data points for which there were sufficient observations to warrant inclusion on the graph. Ratification rates of full democracies are usually higher than, or nearly the same as, those of the group of nations as a whole. ${ }^{180}$

180. When the group of democratic countries is expanded to include all countries with democracy ratings of 6 or above, the curves exhibit a shape nearly identical to that of the full set of countries. For the Covenant on Civil and Political Rights, the ratification rates for countries with democracy ratings of 6 to 10 are $81 \%$ of those with a Fair Trial rating of $1,69 \%$ of those with a rating of $2,78 \%$ of those with a rating of 3 , and $60 \%$ of those with a rating of 4 . For the Optional Protocol, the ratification rates for countries with democracy ratings of 6 to 10 are $63 \%$ of 
FIGURE 3. FAIR TRIALS

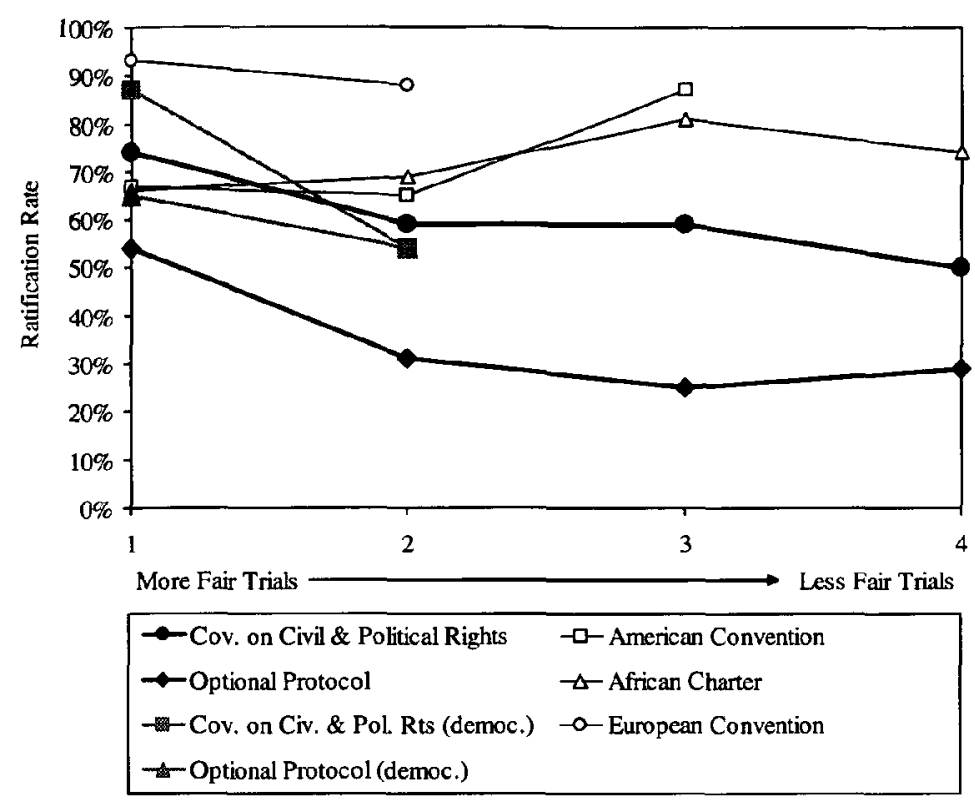

Figure 4, which shows the relationship between Civil Liberty ratings and treaty ratification, displays two sets of patterns. On the one hand, the Covenant on Civil and Political Rights, the Optional Protocol, and the European Convention on Human Rights all have downward sloping curves, with ratification rates falling as Civil Liberty ratings worsen. On the other hand, the American Convention on Human Rights, the African Charter on Human Rights, the Covenant on Civil and Political Rights (limited to full democracies), and the Optional Protocol (limited to full democracies) exhibit a parabolic shape: In each case, the ratification rates for countries with Civil Liberty ratings of 2 or 3 are notably higher than for countries with both better and worse ratings. ${ }^{181}$

those with a rating of $1,48 \%$ of those with a rating of $2,51 \%$ of those with a rating of 3 , and $53 \%$ of those with a rating of 4 .

181. When the group of democratic countries is expanded to include all countries with a democracy rating of 6 or above, the parabolic shape disappears, and the curve reverts to a shape much more similar to that for the set of countries as a whole. For the Covenant on Civil and Political Rights, the ratification rates for countries with democracy ratings of 6 to 10 are $70 \%$ for those with Civil Liberty codes of $1,66 \%$ for those with codes of $2,62 \%$ for those with codes of 3 , $76 \%$ for those with codes of $4,40 \%$ for those with codes of 5 , and $29 \%$ for those with codes of 6 . For the Optional Protocol, the ratification rates for countries with democracy ratings of 6 to 10 are $53 \%$ for those with codes of $1,52 \%$ for those with codes of $2,47 \%$ for those with codes of $3,39 \%$ for those with codes of $4,11 \%$ for those with codes of 5 , and $6 \%$ for those with codes of 6 . There are an insufficient number of observations of democratic countries with codes of 7 to warrant inclusion in the graph. 


\section{FIGURE 4. CIVIL LIBERTY}

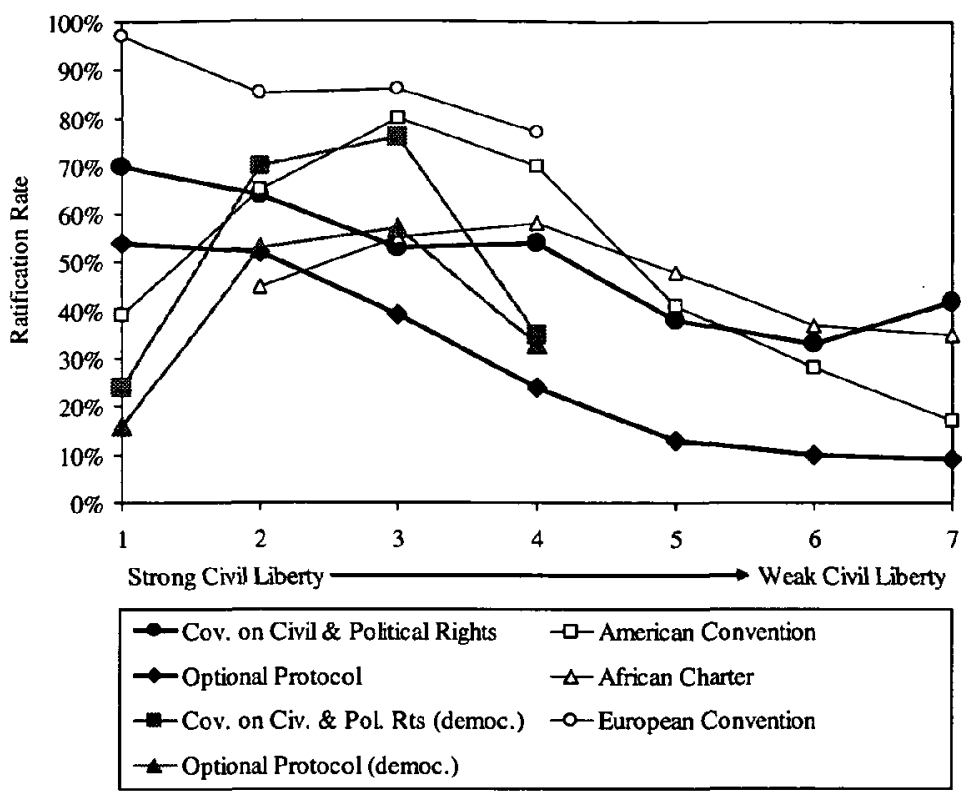

Finally, Figure 5 shows the relationship between the percent of legislators that are male and ratification of the Convention on the Political Rights of Women. To produce the graph, I broke the data into quartiles based on the percent of the legislature made up by men. The result is a gradual downward sloping curve, falling from a high of a $60 \%$ ratification rate for the quarter of countries with the lowest percentage of men in parliament to a low of $37 \%$ for the quarter of countries with the highest percentage of men in parliament. For democracies, the pattern is similar, though the ratification rates are higher across the board and fall off somewhat more quickly between the first and the second quartiles. ${ }^{182}$

182. This observation holds for both the narrower and broader categories of democracy. For countries with democracy ratings of 6 to 10 , the ratification rates are $76 \%$ for the first quartile, $68 \%$ for the second, $57 \%$ for the third, and $45 \%$ for the fourth. 
Figure 5. PERCENTAGe of Men IN PARLiament

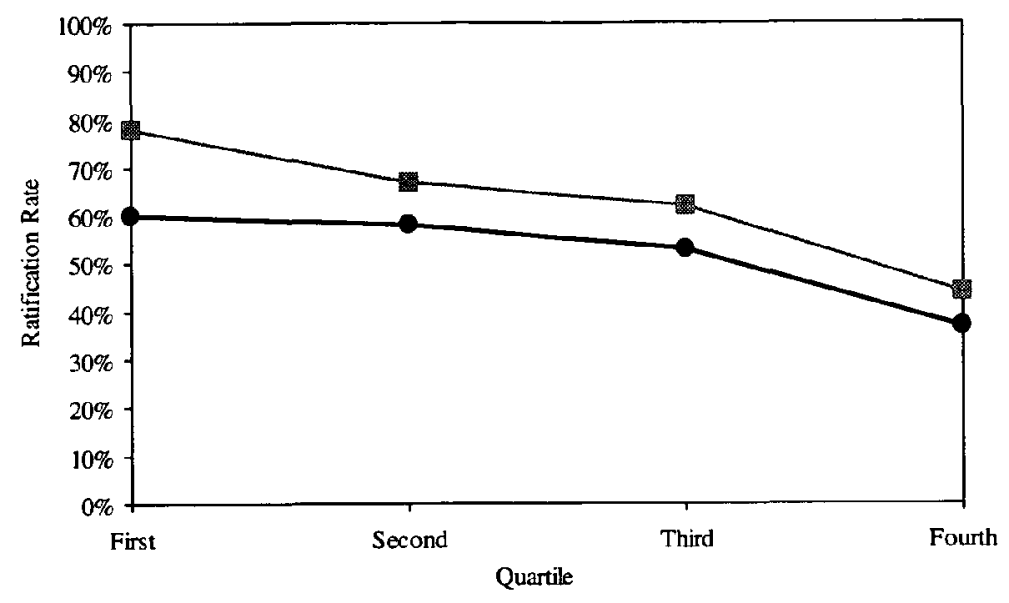

Low Percentage of Men $\longrightarrow$ High Percentage of Men

$\rightarrow$ Convention on the Political Rights of Women

- Convention on the Political Rights of Women (democracy)

The evidence shown in these figures gives reason to question both the normative and the rationalist accounts. Normative theory suggests that the curves will be downward sloping, with higher rates of ratification associated with better human rights practices. Yet as the above figures show, this pattern is only sometimes observed. Moreover, even where the shape of the curve is downward sloping, the ratification levels of the worst human rights offenders remain consistently over $30 \%$, contradicting the suggestion of normative theory that compliance with treaty requirements is the norm. The evidence indicates that noncompliance not only occurs, but is quite common.

Most of the rationalist theories do not fare much better. If treaty ratification is simply cheap talk, as realists would have it, why do we witness patterns in state ratings that show consistent relationships to treaty ratification? If, however, only countries for which compliance is easy-socalled least-cost compliers-sign treaties, as institutionalist theory suggests, then why do we see countries with the worst ratings ratifying treaties at high rates, sometimes even higher than those of the countries with the best ratings? And why are countries with poor ratings much less likely to have ratified the Optional Protocol and Article 21? Liberals seem to have part of the story correct-democracies with worse ratings do have lower rates of ratification. Moreover, full democracies that exhibit the worst human rights 
ratings generally have not ratified treaties at high rates. Nonetheless, liberal theory is unable to explain why full democracies with the best ratings not infrequently have lower ratification rates than those with slightly worse ratings. ${ }^{183}$

Finally, although each theory can account for some of the results, none either individually or collectively can explain why the Torture and Genocide Conventions appear to have the smallest impact on human rights practices of all the universal treaties or why regional treaties seem more likely than universal treaties to exhibit a frequent association between increasing rates of ratification and worsening human rights ratings. And with the possible exception of republican liberal theory, they would be hard-pressed to explain why we often find countries with worse human rights ratings ratifying at higher rates than those with better ratings. ${ }^{184}$ As the discussion below demonstrates, the puzzle only deepens when we examine whether treaty ratification is associated with better or worse human rights ratings than would otherwise be expected.

183. As Figures 2 and 4 show, full democracies (countries with a democracy rating 10 on a scale of 1 to 10) that have the best ratings are less likely to ratify the relevant human rights treaties than are full democracies with slightly worse ratings.

184. For the republican liberal explanation, see Moravcsik, supra note 25, at 225-30. If newly established, unstable democracies have worse practices than established, stable democracies, as my data seem to suggest, then the supposition that newly established and potentially unstable democracies are more likely to be supporters of binding human rights regimes than are either established democracies or nondemocracies might help explain a positive association between ratification and worse human rights practices. See supra text accompanying notes 67-71. It is worth noting, however, that a comparison of the mean ratification rates of newly established democracies (defined here as those with democracy ratings of 8 to 10 on a 1 to 10 scale that were fewer than thirty years old at the time the treaty under examination came into force) with established democracies (defined here as those with democracy ratings of 8 to 10 on a 1 to 10 scale that were thirty years old or more at the time the treaty under examination came into force) across all the country-years following enactment of the treaty under consideration does not show a higher propensity to ratify among newly established democracies. Established democracies are more likely to ratify than newly established democracies in five out of eleven treaties-the Convention on the Political Rights of Women (73\% versus 72\%), Article 21 (19\% versus 14\%), the Optional Protocol (39\% versus 38\%), the Genocide Convention (73\% versus 69\%), and the European Convention on Human Rights (92\% versus $90 \%$ ) - and newly established democracies are more likely to ratify than more established democracies in four out of eleven treaties-the Covenant on Civil and Political Rights (53\% versus $51 \%$ ), the Torture Convention (30\% versus 23\%), the American Convention on Human Rights (77\% versus $46 \%$ ), and the European Torture Convention ( $44 \%$ versus $27 \%$ ). For the remaining two treaties, there were no countries that met the established democracy criteria and hence a comparison was impossible. When the definition of "democracy" is expanded to include countries that are rated 6 to 10 on a 1 to 10 scale, I find that in eight out of eleven treaties, established democracies are more likely to ratify than are newly established democracies, and in one out of eleven treaties-the American Convention on Human Rights-newly established democracies are more likely to ratify than established democracies. Again, for the remaining two treaties, there were no countries that met the "established democracy" criteria. These findings do not preclude the possibility that newly established democracies are more likely to ratify than are established democracies, controlling for other characteristics. This hypothesis will be much more fully tested in a work in progress. See Hathaway, supra note 68 . 


\section{Are Treaties Effective?}

Although the preceding examination of the relationship between treaty ratification and human rights ratings yields interesting insights into country compliance behavior, it has one notable shortcoming: It cannot tell us whether the patterns that we observe are due to the impact of treaties or instead to factors that are associated both with ratification and with countries' human rights ratings. The observation that countries that ratify treaties generally have better human rights ratings on the whole than those that do not does not mean that ratifying countries have better ratings as a result of ratifying the treaties. Rather, it is possible that this observation arises because the same factors that lead to good human rights ratings also lead countries to ratify human rights treaties. For this reason, a demonstration that countries' conduct usually conforms to their voluntarily accepted treaty obligations does not provide an answer to those who are skeptical of international law, as law that has no effect on behavior cannot really be said to be law at all.

In the analyses summarized below, I examine whether countries that have ratified treaties are more likely than they otherwise would be to conform their actions to the requirements of the treaty. In other words, do the treaty requirements appear to be effective in changing countries' practices? The results suggest that not only is treaty ratification not associated with better human rights practices than otherwise expected, but it is often associated with worse practices. Countries that ratify human rights treaties often appear less likely, rather than more likely, to conform to the requirements of the treaties than countries that do not ratify these treaties.

Determining whether countries that have ratified human rights treaties are more likely than we would otherwise expect to act in ways consistent with the requirements of the treaties is not a simple matter. It requires, to begin with, a theory of what factors, other than treaties, affect countries' human rights practices. Fortunately, there is a fairly extensive strain of political science literature that seeks to explain cross-national variation in respect for human rights. ${ }^{185}$ This Article draws on and builds upon these

185. See, e.g., Douglas A. HibBS, JR., Mass Political Violence: A Cross-National CAUSAL ANALYSIS 182 (1973) (finding a positive relationship between "internal war" and "negative sanctions" by government); Conway W. Henderson, Conditions Affecting the Use of Political Repression, 35 J. CONFLICT RESOL. 120, 132 (1991) (conducting a cross-national study for 1986 and finding that democracy and energy consumption per capita (a measure of economic wealth) are negatively correlated with political repression and that inequality is positively correlated with political repression); Conway W. Henderson, Population Pressures and Political Repression, 74 SoC. SCl. Q. 322 (1993) (hypothesizing a link between population density and repression, but finding no statistically significant relationship and finding that population growth has a statistically significant positive relationship to the level of repression); Neil J. Mitchell \& James M. McCormick, Economic and Political Explanations of Human Rights Violations, 40 WORLD POL. 476 (1988) (finding weak support for the contention that wealthier nations have 
earlier studies, using them as a guide to selection of the control variables. Based in part on these studies, the control variables that I expect to be associated with poorer human rights records include international war, civil war, population size, population growth, and whether the regime in power is relatively new. The variables that $I$ expect to be associated with better human rights records include democracy, ${ }^{186}$ gross national product per capita, global economic interdependence, and dependence on foreign aid. I expect economic growth to have both positive and negative effects on human rights practices. ${ }^{187}$ Descriptions of the data sources for these control variables are set out in Appendix B.

Unless otherwise indicated, I also include in the analyses a control variable to capture otherwise unaccounted-for country-to-country variation in the data (a "country dummy" variable), as well as a time-trend variable intended to capture otherwise unaccounted-for variation in the data across time. ${ }^{188}$ The final control variable that $I$ use in the analyses is the prior year's measure of the human rights practice (a "lagged dependent variable"), which I expect to be a strong predictor of a given country's human rights record in any given year. The use of this variable addresses a significant statistical problem that is encountered in analyzing pooled crosssectional data. ${ }^{189}$ With all these controls in place, the crucial variable of interest is whether a nation has signed the relevant human rights treaty. To account for the fact that the effect of treaties may be cumulative and longterm, I measure this variable as a sum of the number of years since the treaty was ratified. ${ }^{190}$

better human rights records than poorer nations); Poe \& Tate, supra note 130 , at $861,866-67$ (finding that population size has a positive and statistically significant impact on political repression and that democracy and economic standing have a negative and statistically significant impact); Steven C. Poe et al., Repression of the Human Right to Personal Integrity Revisited: A Global Cross-National Study Covering the Years 1976-1993, 43 INT'L STUD. Q. 291, 306 (1999) (finding that population size, population growth, and civil war have a positive and statistically significant impact on political repression and that democracy, per capita GNP, and economic growth have a negative and statistically significant impact).

186. It is possible that democracies are not only more likely to have better practices but that they are more likely to have cumbersome ratification processes that lead them to ratify treaties at a lower rate than otherwise expected. Because I control for the level of democracy in the analysis, this dynamic ought not have a substantial effect on the results.

187. Compare Mancur Olson, Rapid Growth as a Destabilizing Force, 23 J. ECON. HIST. 529 (1963) (arguing that economic growth will increase repression because it increases instability), and Conway W. Henderson, Conditions Affecting the Use of Political Repression, $35 \mathrm{~J}$. ConfLICT RESOL. 120, 126 (1991) (hypothesizing that "the greater the rate of growth in the economy, the more likely the government will be to use repression"), with Poe et al., supra note 185, at 294 (suggesting that increasing prosperity has the opposite effect, satisfying those who would otherwise rebel and thereby promoting stability and reducing the need for repression).

188. For more on these variables, see infra Appendix B.

189. See infra notes 326-327 and accompanying text (discussing autocorrelation).

190. I expect that human rights treaties, if they have effects on country practices, do so relatively slowly. See CHAYES \& CHAYES, supra note 1, at 16 ("The effort to protect human rights by international agreement may be seen as an extreme case of the time lag between undertaking and performance."). Operationalizing the treaty variable this way has the effect of 
I obtained the results for all the analyses except that involving the Convention on the Political Rights of Women using ordered probit analysis with robust standard errors. ${ }^{191}$ For the Convention on the Political Rights of Women, I used an ordinary least squares analysis with robust standard errors, because I measure compliance using the percentage of men in the legislature-a continuous variable, as opposed to the ordinal indices I use to measure compliance with the other treaties. ${ }^{192}$ Tables 3 through 5 summarize the direction of the relationship these analyses suggest between the ratification of each identified human rights treaty and relevant country practices. More details regarding the variables and the design of the analyses, as well as the complete results of the analyses, can be found in Appendices B and C.

This approach aims to determine whether country-years in which the analyzed treaty is ratified exhibit better or worse human rights ratings than would otherwise be expected. ${ }^{193}$ Because the analyses use both time series and cross-national data, the results capture both across-country and acrosstime variation in country ratings. In other words, the analyses show whether, controlling for other factors, there are either systematic differences between the measures of human rights practices of countries that have

magnifying changes in country practices over time, whether positive or negative. See infra note 298.

191. I use ordered probit analysis here because the dependent variable data are ordinal. See Tim Futing LiaO, InTERPReting Probability MODEls: Logit, Probit, and Other GENERALIZED LINEAL MODELS 37 (1994). The drawback of using this model, however, is that the coefficients are not as easily interpreted. See id. at 37-47; see also WILLIAM H. GREENE, ECONOMETRIC ANALYSIS (4th ed. 2000). Although the coefficients from an ordered probit analysis are indicative of the relationship between the independent variables and the dependent variable, the coefficients cannot be interpreted as the marginal effects of the independent variables on the dependent variable (as they can, for instance, with the ordinary least squares model). To discern the marginal effects of the independent variables on the dependent variable, additional calculations are required. Greene explains:

In the general case, relative to the signs of the coefficients, only the signs of the changes in $\operatorname{Prob}(y=0)$ and $\operatorname{Prob}(y=J)$ are unambiguous! The upshot is that we must be very careful in interpreting the coefficients in th[e] [ordered probit] model. ... Indeed, without a fair amount of extra calculation, it is quite unclear how the coefficients in the ordered probit model should be interpreted.

GREENE, supra, at 877-78.

192. Because Men in Parliament is a percentage bounded between 0 and 1 , a tobit model is arguably more appropriate here. J. SCOTT LONG, REGRESSION MODELS FOR CATEGORICAL AND Limited DePENDENT VARIABles 212-13 (1997). However, the tobit model yields the same results for the purposes of this Article as the ordinary least squares (OLS) model, which yields coefficients that are more easily interpreted. The coefficient for ratification of the Convention on the Political Rights of Women using either a two-limit or a right-censored tobit model is -0.00005 , with a standard error of 0.00006 . The coefficient is not statistically significant. The coefficient for ratification of the Convention on the Political Rights of Women by fully democratic countries using either tobit model is -0.0004 , with a standard error of 0.0001 . It is statistically significant at the $99 \%$ level.

193. Linda Camp Keith takes a similar approach to an analysis of the relationship between ratification of the Covenant on Civil and Political Rights and countries' human rights practices. Although Keith uses a somewhat different model (she employs ordinary least squares), her results for this treaty are quite similar to mine. Keith, supra note 2, at 110-12. 
ratified treaties and those that have not, or systematic differences between the period before they have ratified treaties and the period after they have done so. If treaty ratification is associated with better ratings (fewer detected violations) than otherwise expected, that should be indicated by a statistically significant and negative coefficient for the treaty variable. If treaty ratification is associated with worse ratings (more violations) than otherwise expected, that should be indicated by a statistically significant and positive coefficient for the treaty variable. Hence, in the following tables, a positive sign indicates that a country's human rights ratings tend to be worse if a country has ratified, whereas a negative sign indicates that they tend to be better.

Before reviewing the results produced by this approach, it is worth once again noting that multivariate quantitative analysis, no matter how carefully done, is a useful but imperfect tool for examining complex questions of human action. ${ }^{194}$ The results of the analyses below therefore do not provide a definitive answer to the question posed by this Article. The findings do, however, provide some important insights into the effect of treaties on country practices and, in turn, suggest promising avenues for future research.

Table 3 summarizes the results for five universal human rights treaties and the optional provisions of the Torture Convention and the Covenant on Civil and Political Rights, provisions that must be separately ratified in order to be binding. This summary shows that, when the treaty ratification variable is statistically significant, it is associated with worse human rights ratings than would otherwise be expected (as noted earlier, a positive sign indicates more observed violations). Consider, for example, the Genocide Convention. The positive and statistically significant coefficient for the treaty variable in the analysis indicates that countries that have ratified the Genocide Convention have more violations, on average, than those that do not, controlling for a range of country characteristics, otherwise unaccounted-for change over time, and country-to-country variation. The

194. There are several potential concerns regarding the statistical analysis below, including most notably selection bias, measurement error, and lack of mutual independence of the units. I discuss selection bias and systematic measurement error, both of which can bias results, in more depth infra notes 213-214 and accompanying text. The assumption of mutual independence of the units can also be a problem with analyses of pooled cross-sectional data (here, the data set includes multiple years for single countries). Scholars have proposed various correctives, but each has its weaknesses. See Morris P. Fiorina, Divided Government in the American States: A Byproduct of Legislative Professionalism, 88 AM. POL. SCI. ReV. 304, 309 (1994); James Stimson, Regression in Space and Time: A Statistical Essay, 29 AM. J. POL. SCl. 914, 945 (1985). My use of a dummy variable for each country and a lagged dependent variable should partially address the mutual independence problem, see Fiorina, supra, at 309, though it is impossible to rule out the possibility that there is some remaining effect on the statistical significance of the coefficients. 


\section{TABLE 3. RELATIONSHIP BETWEEN TREATY RATIFICATION AND HUMAN RIGHTS RATINGS (UNIVERSAL TREATIES)}

\begin{tabular}{|l|l|c|c|}
\hline Treaty & Human Rights Measure & $\begin{array}{c}\text { Dircction of } \\
\text { Relationship }\end{array}$ & $\begin{array}{c}\text { R-Squared } \\
\text { or Pseudo } \\
\text { R.Squared }\end{array}$ \\
\hline Genocide Convention & Genocide & + & 0.42 \\
\hline Genocide Convention & $\begin{array}{l}\text { Genocide } \\
\text { (no country dummies) }\end{array}$ & $(+)$ & 0.51 \\
\hline Torture Convention & Torture & $(+)$ & 0.39 \\
\hline Torture Convention & $\begin{array}{l}\text { Torture } \\
\text { (no country dummies) }\end{array}$ & + & 0.31 \\
\hline Article 21 & Torture & $(+)$ & 0.39 \\
\hline $\begin{array}{l}\text { Covenant on Civil and } \\
\text { Political Rights }\end{array}$ & Fair Trial & $(+)$ & 0.31 \\
\hline Optional Protocol & Fair Trial & $(-)$ & 0.30 \\
\hline $\begin{array}{l}\text { Covenant on Civil and } \\
\text { Political Rights }\end{array}$ & Civil Liberty & $(-)$ & 0.61 \\
\hline Optional Protocol & Civil Liberty & $(+)$ & 0.61 \\
\hline $\begin{array}{l}\text { Conv. on the Political } \\
\text { Rights of Women }\end{array}$ & $\begin{array}{l}\text { Percentage of Men in } \\
\text { Parliament }\end{array}$ & $(-)$ & 0.87 \\
\hline
\end{tabular}

Note: Except where otherwise indicated, these results control for country characteristics through the use of country dummy variables. All results appearing in parentheses are not statistically significant at the $95 \%$ level. ${ }^{195}$

statistical significance does not hold, however, when I omit controls for country-specific effects. In both the analysis in which country dummies are used and in the analysis in which they are omitted, all the other substantive variables that are statistically significant are significant in the expected direction, with a single exception. ${ }^{196}$ Together, the variables account for $42 \%$ of the variation in the measure of genocide when country dummies are included and $51 \%$ of the variation when they are not (indicated by a pseudo $\mathrm{R}$-squared of 0.42 and 0.51 , respectively).

195. Tests of statistical significance are intended to show whether " a difference is real, or just due to a chance variation." DAVID FREEDMAN ET AL., STATISTICS 487 (1980). A test of significance only matters, therefore, when there is a possibility of chance variation. It is common accepted practice to regard a time series such as that in use here " as being an observation made on a family of random variables." Emanuel Parzen, An Approach to Time Series Analysis, 32 ANNALS MATHEMATICAL STAT. 951, 952 (1961); see also Keith, supra note 2, at 102 (presenting the results of multivariate analyses using a database including 178 countries over an eighteen-year period); Simmons, supra note 2, at 829-30 (presenting the results of multivariate analyses using a database including 133 countries over periods averaging twenty years).

196. The sign for the aid dependency variable in the analysis that includes country dummies has the opposite sign from what I would have expected. See Table 8, infra Appendix C. 
The results for the Torture Convention are similar. Although the treaty variable is not statistically significant when dummy variables for each country are included, it is statistically significant and positive without them. In both cases, the results for the other substantive variables that are statistically significant have the expected signs. The analyses account for $39 \%$ of the difference in Torture ratings when dummy variables for countries are included in the analysis and $31 \%$ of the difference in Torture ratings when dummy variables for countries are not included.

The results for the remaining treaties consistently show no statistically significant relationship between treaty ratification and human rights ratings. Countries that ratify Article 21 of the Torture Convention do not show a statistically significant difference in measured torture levels from what would otherwise be expected; those that ratify the Covenant on Civil and Political Rights or the Optional Protocol do not show a statistically significant difference in the measures of fair trial practices and civil liberties; and those that ratify the Convention on the Political Rights of Women do not show a statistically significant difference in the percentage of men in parliament. In every case, virtually all the other substantive variables that are significant have the expected sign. ${ }^{197}$ The null result for the treaties appears to be relatively robust: Except where otherwise indicated, the treaty variables remain statistically insignificant when I drop country dummies from the analyses and when I rerun the analyses using only the statistically significant variables and the treaty variables (the results of these analyses are not included in the table unless their results differ importantly). Taken together, the results for the group of universal treaties indicate that treaty ratification is usually not associated with statistically significantly different human rights ratings from what would otherwise be expected. More surprisingly, however, when ratification is associated with statistically significantly different human rights ratings, it is associated with worse, rather than better, human rights ratings than would otherwise be expected.

The results for similar analyses of regional human rights treaties lend credence to these findings. Table 4 summarizes the results for the five regional treaties, the impact of some of which is assessed using two or three

197. The most unexpected result is the finding that state failure has a statistically significant negative relationship to the measure of fair trials when ratification of the Covenant on Civil and Political Rights is used as the treaty variable. See $\mathrm{id}$. There are a couple of possible explanations for this unexpected result. One is that the source of information for the index of fair trials, the State Department, might have had difficulty collecting information regarding government trial practices during times of state government collapse, thus leading to lower (hence better) Fair Trial ratings during these periods. The other unexpected result is the positive relationship between democracy and the percentage of men in parliament, which runs contrary to the presumption that democracy should be associated with better human rights records. See id. This result is not entirely surprising, however, given that quotas requiring minimum levels of female representation in parliament are more common in nondemocratic states than in democratic ones. 
different measures of human rights practices addressed by the treaties. As with the assessment of compliance, I test the effectiveness of regional treaties for ratifying countries only against nonratifying countries that are members of the regional organization sponsoring the relevant treaty (which therefore could have joined the treaty at issue). ${ }^{198}$

\section{TABLE 4. RELATIONSHIP BETWEen TREATY RATIFICATION AND HuMAN RightS RATINGS (REgIONAL TREATIES)}

\begin{tabular}{||l|l|c|c|}
\hline Treaty & Human Rights Measure & $\begin{array}{c}\text { Direction of } \\
\text { Relationship }\end{array}$ & $\begin{array}{c}\text { R-Squared } \\
\text { or Pseudo } \\
\text { R-Squared }\end{array}$ \\
\hline $\begin{array}{l}\text { American Torture } \\
\text { Convention }\end{array}$ & Torture & + & 0.35 \\
\hline $\begin{array}{l}\text { African Charter } \\
\text { on Human Rights }\end{array}$ & Torture & $(-)$ & 0.28 \\
\hline $\begin{array}{l}\text { African Charter } \\
\text { on Human Rights }\end{array}$ & $\begin{array}{l}\text { Torture } \\
\text { (no country dummies) }\end{array}$ & + & 0.23 \\
\hline $\begin{array}{l}\text { European Torture } \\
\text { Convention }\end{array}$ & Torture & $(+)$ & 0.44 \\
\hline $\begin{array}{l}\text { American Convention } \\
\text { on Human Rights }\end{array}$ & Fair Trial & $-{ }^{\mathrm{a}}$ & 0.46 \\
\hline $\begin{array}{l}\text { African Charter } \\
\text { on Human Rights }\end{array}$ & Fair Trial & $(+)$ & 0.25 \\
\hline $\begin{array}{l}\text { European Convention } \\
\text { on Human Rights }\end{array}$ & Fair Trial & + & 0.36 \\
\hline $\begin{array}{l}\text { European Convention } \\
\text { on Human Rights }\end{array}$ & $\begin{array}{l}\text { Fair Trial } \\
\text { (no country dummies) }\end{array}$ & + & 0.57 \\
\hline $\begin{array}{l}\text { American Convention } \\
\text { on Human Rights }\end{array}$ & Civil Liberty & + & 0.57 \\
\hline $\begin{array}{l}\text { African Charter } \\
\text { on Human Rights }\end{array}$ & Civil Liberty & $-{ }^{a}$ & 0.54 \\
\hline $\begin{array}{l}\text { European Convention } \\
\text { on Human Rights }\end{array}$ & $\begin{array}{l}\text { Civil Liberty } \\
\text { (no country dummies) }\end{array}$ & $(+)$ & 0.70 \\
\hline
\end{tabular}

${ }^{\mathbf{a}}$ The results for the treaty variable for the American Convention on Human Rights (with Fair Trial as the dependent variable) and the African Charter on Human Rights (with Civil Liberty as the dependent variable) are not stable across alternative specifications.

The results of these analyses suggest that ratification of regional human rights treaties is not infrequently associated with worse than expected human rights practices. Of the three regional treaties on torture, one (the European Torture Convention) shows no statistically significant relationship between treaty ratification and torture; one (the African Charter on Human Rights) shows a statistically significant positive relationship

198. Hence, I limited the database to members of the OAS for the analyses involving American treaties, to members of the OAU for analyses involving African treaties, and to members of the $\mathrm{COE}$ for analyses involving European treaties. 
between ratification and Torture ratings (meaning that ratification is associated with more recorded torture), but only when country dummies are omitted from the analysis; ${ }^{199}$ and one (the American Torture Convention) shows a statistically significant positive relationship between ratification and Torture ratings both when country dummies are included and when they are not (only the results for the former analysis are presented). Except where otherwise indicated, the results for the treaty variables are the same when I omit country dummies and when I drop nonsignificant variables.

I obtain similar results in my analyses of the relationship between countries' Fair Trial ratings and ratification of regional human rights treaties requiring fair trial practices. Of the three relevant regional treaties, two have statistically significant relationships to countries' reported fair trial practices. I find a statistically significant and negative relationship between ratification of the American Convention on Human Rights and the Fair Trial measure. If accurate, this result would be the first instance thus far in which ratification of a human rights treaty is associated with better ratings. Unfortunately, there is reason to doubt the results: Unlike the others, they are not stable across alternative specifications. In contrast to the American Convention, the African Charter on Human Rights appears to have no statistically significant relationship to the Fair Trial measure. And I find a positive and statistically significant relationship between ratification of the European Convention on Human Rights and the Fair Trial measure, suggesting that ratification of the European Convention on Human Rights is associated with more unfair trials. Because of the small number of observations for this analysis, it is impossible to include both country dummies and all of the substantive control variables. When I run the analysis with country dummies but omit all other control variables except the lag variable, I find a statistically significant and positive relationship. I find similar results when I run the analysis with all of the control variables but without country dummies. The analyses explain between $25 \%$ and $57 \%$ of the variation in the Fair Trial index, but the results for a few of the variables are not as expected. ${ }^{200}$

199. See infra Appendix B, Section $\mathrm{M}$ (explaining the reasons for including country dummies in the analyses).

200. In the analysis of the European Convention on Human Rights, the coefficient for "new regime" is significant and negative, suggesting that new regimes provide fairer trials than would otherwise be expected given other country characteristics. Similarly, in the analysis for the African Charter on Human Rights, the coefficients for "international war" and "state failure" are significant and negative, suggesting that countries engaging in war and experiencing state failure provide faires trials than would otherwise be expected. These results may be due to the difficulties presented to the State Department, which constructs the Country Reports on Human Rights from which I drew the index, in obtaining information on the fair trial practices of countries during times of upheaval (such as war and regime transition), and its practice of giving the benefit of the doubt to newer regimes in compiling the reports. 
The relationship between ratification of regional human rights treaties and civil liberties is also mixed. On the one hand, ratification of the American Convention on Human Rights is associated with worse Civil Liberty ratings than expected. On the other hand, ratification of the African Charter on Human Rights is associated with better Civil Liberty ratings than expected. Once again, however, this encouraging finding for the efficacy of international human rights law does not hold: The latter result is not stable across alternative specifications. The European Convention on Human Rights splits the difference, showing no statistically significant relationship between treaty ratification and Civil Liberty ratings. (I was unable to obtain any results using country dummies, probably because of insufficient variation in the dependent variable in many European countries.) The analyses predict a large percentage of the variation in the Civil Liberty ratings-between $54 \%$ and $70 \%$ - but the results for some of the control variables are not as expected. ${ }^{201}$

In order to test the prediction of liberal theory that democratic countries will be more likely to change their behavior in response to their international legal commitments, I reran the analyses of the universal treaties including an additional variable that tests the impact of treaty ratification on measures of human rights for countries with democracy ratings of $10 .{ }^{202}$ As summarized in Table 5, the results suggest that fully democratic countries may sometimes be more likely to have better human rights practices if they ratify a human rights treaty than would otherwise be expected. Most notably, when the data set is limited to countries with some variation in their Genocide levels, fully democratic countries that ratify the Genocide Convention have statistically significantly better Genocide ratings than expected. This lies in direct contrast to the results for the group of nations as a whole, as summarized in Table 3. And whereas ratification of the Optional Protocol and Convention on the Political Rights of Women bears no apparent relationship to the practices of the group of nations as a whole, fully democratic countries that ratify the Optional Protocol have statistically significantly better Civil Liberty ratings and those that ratify the Convention on the Political Rights of Women have a statistically

201. In the analysis of the European Convention on Human Rights, the coefficient for international war is significant and negative (indicating that it is associated with better Civil Liberty ratings) and the coefficient for aid dependency is significant and positive (indicating that it is associated with worse Civil Liberty ratings).

202. This variable is created by interacting the treaty variable with a new dummy variable that indicates 1 only where the country's democracy rating is 10 and 0 elsewhere. In addition, I added the new dummy variable labeled "full democracy" in Table 10 as a separate independent variable to ensure that the results for the interacted variable would accurately reflect only the impact of treaty ratification for fully democratic countries. 
TABLE 5. ReLATIONSHIP BETWEEN TREATy RATIFICATION AND HUMAN RightS RATINGS (FULly DEMOCRATIC NATIONS)

\begin{tabular}{|c|c|c|c|}
\hline Treaty & Human Rights Measure & $\begin{array}{l}\text { Direction of } \\
\text { Relationship }\end{array}$ & $\begin{array}{l}\mathrm{R}-\text { Squared } \\
\text { or Pseudo } \\
\mathrm{R}-\text { Squared }\end{array}$ \\
\hline Genocide Convention $^{a}$ & Genocide & - & 0.12 \\
\hline Torture Convention & Torture & + & 0.38 \\
\hline Article 21 & Torture & + & 0.38 \\
\hline $\begin{array}{l}\text { Covenant on Civil and } \\
\text { Political Rights }\end{array}$ & Fair Trial & $(+)$ & 0.31 \\
\hline Optional Protocol & Fair Trial & $(+)$ & 0.31 \\
\hline $\begin{array}{l}\text { Covenant on Civil and } \\
\text { Political Rights }\end{array}$ & Civil Liberty & $(-)$ & 0.61 \\
\hline Optional Protocol & Civil Liberty & - & 0.61 \\
\hline $\begin{array}{l}\text { Conv. on the Political } \\
\text { Rights of Women }\end{array}$ & $\begin{array}{l}\text { Percentage of Men in } \\
\text { Parliament }\end{array}$ & - & 0.87 \\
\hline
\end{tabular}

${ }^{a}$ Genocide Convention results include countries with democracy ratings from 8 to 10 .

significantly lower percentage of men in parliament. The Torture Convention, however, appears to have the same effect on full democracies that it does on the group of countries as a whole: The results for this treaty variable are statistically significant and positive, indicating that fully democratic nations that ratify the treaty appear to engage in more violations than would otherwise be expected (this contrasts with positive but insignificant results for the group of nations as a whole that ratify the treaty, except when the impact of the Torture Convention is measured without country dummies). ${ }^{203}$ Article 21 has a similar effect on full democracies (this contrasts with positive but insignificant results for the group of nations as a whole). Finally, ratification of the Optional Protocol has no statistically significant relationship to Fair Trial ratings of full democracies, and ratification of the Covenant on Civil and Political Rights has no statistically significant relationship to either the Fair Trial or the Civil Liberty ratings of

203. These results may initially appear to contradict the findings summarized in Figure 2 , which show ratification rates of the Torture Convention for full democracies initially rising and then falling off precipitously as Torture ratings rise, suggesting that for full democracies, worse practices are associated with lower, not higher, ratification rates. But what Figure 2 does not show is that the number of countries in each category is lower as Torture ratings rise, with 226 observations for a 1,142 for a 2 , and 55 for a 3 . The analysis summarized in Table 5 treats each observation equally, thus the higher ratification rate for countries with a rating of 2 than for those with a 1 has a large impact on the results, as does controlling for a variety of other factors that influence human rights practices. 
full democracies (the results are the same for the group of nations as a whole). For the most part, these largely encouraging results do not hold when the universe of democratic nations is expanded to include countries with democracy ratings of 6 to $10 .^{204}$

Taken as a whole, the empirical evidence regarding the patterns of human rights treaty compliance appears largely inconsistent with existing theories. First and foremost, although countries that ratify treaties usually have better ratings than those that do not, ${ }^{205}$ noncompliance appears common. ${ }^{206}$ Indeed, those with the worst ratings sometimes have higher rates of treaty ratification than those with substantially better ratings. Second and relatedly, treaty ratification is not infrequently associated with worse, rather than better, human rights ratings than would otherwise be expected ${ }^{207}$ Unexpectedly, treaty ratification is more often associated with worse human rights ratings in areas where rights are deeply entrenched in international law than in areas that are of more recent provenance. ${ }^{208}$ Third, noncompliance appears less common and less pronounced among countries that have ratified the Optional Protocol to the Covenant on Civil and Political Rights and Article 21 of the Torture Convention, and countries that have ratified these provisions generally have substantially better human rights ratings than those that have not. ${ }^{209}$ However, it is possible that this is due largely to a greater proclivity among those with better practices to sign

204. Only the Genocide Convention shows significant and negative results for the larger group of democratic nations (suggesting that practices of ratifying countries are better than otherwise predicted). In every other case, the results are either not significant or are significant and positive (suggesting worse practices for democratic ratifying countries). For the Genocide Convention, the coefficient for the interacted variable is -0.034 (significant at the $95 \%$ level), and the standard error is $\mathbf{0 . 0 1 3}$. For the Torture Convention, the coefficient for the interacted variable is -0.030 (not significant), and the standard error is 0.036 . For Article 21 , the coefficient for the interacted treaty variable is 0.017 (not significant), and the standard error is 0.061 . For the Covenant on Civil and Political Rights (with Fair Trial as the dependent variable), the coefficient is 0.052 (not significant), and the standard error is 0.031. For the Optional Protocol (with Fair Trial as the dependent variable), the coefficient for the interacted variable is 0.075 (significant at the $95 \%$ level), and the standard error is 0.036 . For the Covenant on Civil and Political Rights (with Civil Liberty as the dependent variable), the coefficient for the interacted variable is -0.010 (not significant), and the standard error is 0.010 . For the Optional Protocol (with Civil Liberty as the dependent variable), the coefficient for the interacted variable is 0.029 (significant at the $95 \%$ level), and the standard error is $\mathbf{0 . 0 1 3}$. For the Convention on the Political Rights of Women, the coefficient for the interacted variable is 0.0001 (not significant), and the standard error is 0.0002 .

205. See Table 1, supra Section II.B (comparing the mean rating for countries that have ratified treaties to the mean rating of those that have not).

206. This is revealed most strikingly by Figures 1-5, supra Section II.B, which show that countries with the worst human rights ratings often have very high rates of treaty ratification.

207. See Tables 3-4, supra.

208. Most notably, as Table 3, supra, shows, ratification of the Genocide and Torture Conventions is associated with statistically significantly worse Genocide and Torture ratings. Ratification of the other universal treaties, on the other hand, has no statistically significant relationship to human rights ratings.

209. See Table 1 and Figures 2-4, supra Section II.B. 
the provisions rather than to the effect of the provisions on state behavior. ${ }^{210}$ Fourth, ratification of regional treaties appears to be more likely than ratification of universal treaties to be associated with high rates of noncompliance and with worse human rights practices than would otherwise be expected. ${ }^{211}$ Finally, full democracies appear to be more likely to comply with their human rights treaty obligations than the group of nations as a whole and more likely when they ratify treaties to have better practices than otherwise expected. ${ }^{212}$

There are two possible nonsubstantive explanations for these results. First, it is possible, though not likely, that the results are due in part or whole to systematic measurement error. Such measurement error may account in part for the correlation between ratification of treaties and worse human rights ratings than otherwise expected if it is, for instance, more difficult to get information about the human rights practices of countries that have not ratified treaties than it is to get information about those that have. There are good reasons to believe that such measurement error does not account for the results of the analyses, ${ }^{213}$ but the possibility cannot be entirely ruled out.

210. The analyses summarized in Tables 3-5, supra, suggest that countries that have ratified the Optional Protocol and Article 21 have no better practices than would otherwise be expected, and indeed ratification of Article 21 by fully democratic countries is associated with worse Torture ratings.

211. The comparison of means in Table 1, supra Section II.B, for example, indicates that countries that ratify the regional treaties that address torture and fair trial practices generally have worse average ratings than those that do not. Figures 2-4, supra Section II.B, show that, in the torture, fair trial, and civil liberty areas, poor human rights ratings are associated with high rates of ratification of regional human rights treaties. And the statistical analyses summarized in Table 4 , supra, indicate that many of the regional treaties analyzed are associated with worse, rather than better, human rights ratings than otherwise expected.

212. Although the mean human rights ratings of full democracies that have ratified are not substantially different from the ratings of those that have not, see Table 2, supra Section II.B, the means are better across the board for full democracies. In part because full democracies do not tend to engage in the worst human rights violations, they do not tend to have high rates of ratification associated with poor ratings. See Figures 2-4, supra Section II.B. Most strikingly, full democracies appear to be more likely to improve their practices when they ratify universal treaties than is the group of nations as a whole, as the results summarized in Table 5, supra, suggest.

213. First, the uniformity of the results across different subject areas evaluated with different sources of data suggests that a reporting effect is unlikely to be the source of the counterintuitive finding. Second, and more important, in the instances in which I can directly evaluate the impact of ratification on the evaluation of human rights practices-in my coding of the State Department Country Reports on Human Rights-I find that when treaty ratification is noted, the reports almost universally appear to give countries lighter, rather than heavier, scrutiny for the year of ratification and for a short period thereafter. In essence, the reports appear to give newly ratifying countries the benefit of the doubt in the immediate wake of treaty ratification. If this observation is correct, this would suggest that the results understate, rather than overstate, the association of treaty ratification with worse human rights practices. And finally, if the results were due to greater reporting of violations in the wake of treaty ratification, we would expect to find that ratification would always or nearly always be associated with higher violation ratings. But instead the results suggest that the association between ratification and practices is strongest in the most entrenched areas of human rights and for regional treaties-variations that are difficult to explain by sole reference to a reporting effect. 
Second, the results might be affected by reciprocal causation. It could be, after all, that the relationship between treaties and practices runs the other direction. We have already seen that countries with poorer human rights ratings are sometimes more likely to sign human rights treaties than those with somewhat better ratings. It might be supposed, as a result, that the finding of an apparent negative association between treaties and practices is due to this tendency (practices causing ratification) rather than to any actual effects that treaties have on practices. Recall, however, that the analysis controls for a wide array of factors expected to shape the human rights practices of countries. Reciprocal causation would bias the results only to the extent that countries with worse practices are more likely to ratify than those with better practices, controlling for the influence of these factors. ${ }^{214}$ Yet I cannot at this point rule out the possibility that counterintuitive results of the analysis are due to a perverse selection effect.

Bearing these reasons for caution in mind, it is nonetheless the case that much of the evidence regarding the apparent relationship between human rights treaty ratification and human rights practices is perplexing for advocates of idealism and rationalism alike. Contrary to the predictions of normative theory, treaty ratification appears to be frequently associated with worse, rather than better, human rights practices. Even more confoundingly, this adverse relationship between treaty ratification and country human rights ratings appears more pronounced in the most established areas of human rights-torture and genocide-and for regional treaties. Rationalist theories also face anomalies. Contrary to realists' expectations, ratification is not simply (or at least not always) epiphenomenal. Rather, ratification appears sometimes to have an effect on practices, simply not the effect one would anticipate. Institutionalists, like normative scholars, expect treaty ratification to be associated with better human rights practices, at a minimum because they expect the least-cost compliers to be more likely to ratify the treaties than countries for which compliance would be more costly. Of the existing theories, liberal theory appears the most promising, as it correctly predicts that democracies will be more likely than others to have better human rights ratings when they ratify treaties. But liberals are for the most part unable to explain why ratification of treaties on the whole, and of regional treaties in particular, often appears to be associated with worse human rights practices than would otherwise be expected. ${ }^{215}$ Nor can they explain why fully democratic nations have worse

214. There are statistical methods for addressing selection bias, but using them would require identifying an instrumental variable for the human rights practice that is uncorrelated with the probability of ratification-something I have thus far been unable to do. See Joshua D. Angrist et al., Identification of Causal Effects Using Instrumental Variables, 91 J. AM. STAT. ASS'N 444 (1996).

215. Even if newer democracies have worse practices than established democracies and are more likely to join human rights treaties more readily than are established democracies, this 
Torture ratings when they ratify the Torture Convention than would otherwise be expected. In the next Part, I consider a possible explanation for the empirical findings and seek to place the insights of liberal theory into a broader context.

\section{The Dual Roles of Human Rights Treaties}

Previous analyses of treaty compliance have focused primarily on the direct effect of the binding commitment of ratification on country practices. Rationalists for the most part claim that countries will comply with treaties only when doing so enhances their interests, whether those interests are defined in terms of geopolitical power, reputation, or domestic impact. Normative scholars, on the other hand, claim that strict self-interest is less important to understanding international law compliance than is the persuasive power of legitimate legal obligations. Neither considers the possibility that countries comply (or fail to comply) with treaties not only because they are committed to or benefit from the treaties, but also because they benefit from what ratification says to others. In contrast to these approaches, my argument is that we cannot fully understand the relationship between human rights treaty ratification and human rights practices unless we understand that treaties operate on more than one level simultaneously. They create binding law that is intended to have particular effects, and they express the position of those countries that join them. Like other political instruments, in short, treaties play both instrumental and expressive roles. ${ }^{216}$ This theory of the dual roles of human rights treaties draws upon and throws new light on both the normative and rationalist models of international law compliance-and, I argue, may provide a missing key to explaining the paradoxical patterns of interaction between human rights treaty ratification and human rights practices.

Before turning to this explanation, however, it is important to consider why human rights treaties so often appear to have no statistically significant effect on practices. Although treaty ratification does often appear to be associated with worse human rights treaty practices-a result that is counterintuitive and therefore demands explanation-there are more instances in which treaty ratification has no apparent impact. Although we should be wary of reading too much into a null result, we also cannot ignore

selection effect would likely not explain the results reported here. $C f$. supra note 184 . The analyses in this Section, unlike those in the previous Section, test for whether practices are better or worse than they otherwise would have been, given other country characteristics (including level of democracy and whether the regime is new or not).

216. See MurRay Edelman, THE SYMBOLIC USES OF POLITICS 12 (1977) ("In Himmelstrand's terms, political acts are both instrumental and expressive."). 
it. It is striking, after all, that treaties, even though they do not consistently make practices worse, seem so consistently not to make them better.

There are any number of possible explanations for these findings. Much of the strength of international human rights law comes from NGOs and Western liberal states' critical attention to nations with poor human rights practices. However, neither NGOs nor Western states tend to limit their focus to treaty ratifiers. Indeed, as discussed below, the opposite may be true. The increasingly pervasive culture of human rights and processes of norm internalization tend to affect states regardless of whether they have ratified particular treaties. Perhaps this is due in part to the fact that UN Charter-based mechanisms may act against ratifiers and nonratifiers alike. In the regional context, we might also expect few differences between ratifying and nonratifying states because regional bodies-particularly the Council of Europe (COE) and the Organization of American States (OAS) - place requirements on members that make ratification of an individual treaty either mandatory or superfluous-in either case, the treaty might reasonably be expected to have little independent effect on practices. ${ }^{217}$

It is also possible that these findings are due at least in part to the heavy resistance of nations' human rights practices to change. ${ }^{218}$ With few exceptions, the lagged dependent variable in the model summarized in Tables 3-5 is statistically significant and positive, indicating that one of the best predictors of a country's rating in a given year is its rating the previous year. ${ }^{219}$ This consistency in ratings over time is probably due at least in part to the central role that bureaucratic inertia plays in government abuses of human rights. Individuals and institutions become habituated to the use of repressive means of retaining control. As a result, repressive behavior lingers long after the initial impetus for it disappears. The more government employees use repressive tactics, the more accepted such tactics become. At the same time, governments build up institutions around the use of these practices, and the institutions and individuals needed to manage conflict using nonrepressive means disappear or perhaps are never part of government in the first place. In short, governments and the individuals who make decisions within them become habituated to engaging in human rights violations, and this behavior takes time and continued conscious effort to change. Major shocks to the system-such as a change in government-provide limited windows of opportunity for effecting large

217. I am grateful to Douglass Cassel for immensely thoughtful comments on this topic.

218. This resistance to change might even loosely be called "path-dependent." See, e.g., Oona A. Hathaway, Path Dependence in the Law: The Course and Pattern of Legal Change in a Common Law System, 86 IOWA L. REV. 601 (2001). Chayes and Chayes refer to this resistance to change in the human rights area as a "time lag." See CHAYES \& CHAYES, supra note 1, at 16.

219. See Tables 8-10, infra Appendix C. 
changes in the system. Indeed, when major changes in human rights practices occur, it is often because of such an event. ${ }^{220}$ But even then, change is not inevitable; to the extent that low-level government officials remain in place during shifts in the top levels of government, government oppressive practices often remain as well. ${ }^{221}$ The same is of course true of countries that observe human rights. Once norms favoring human rights are entrenched, they can be difficult to dislodge.

But this does not tell the entire story, for human rights practices do change and are often responsive to human rights treaty ratification as well as other factors. The major task of this Part, then, is to suggest how we might begin to explain the unexpected patterns that emerge from the quantitative analysis-why, that is, countries with worse human rights practices sometimes appear to ratify treaties at higher rates than those with better practices, why treaty ratification often appears to be associated with worse human rights practices than otherwise expected, why noncompliance is apparently less pronounced among countries that have ratified the Optional Protocol and Article 21, why ratification of regional treaties appears more likely to worsen human rights practices than to improve them, and why, finally, full democracies appear more likely when they ratify treaties to have better practices than otherwise expected. The dual nature of treaties-as instrumental and expressive tools-provides a starting point for explaining these results.

The instrumental role of treaties is well understood. I therefore focus here primarily on outlining the expressive role of treaties. The notion that the law has an "expressive" function is not new, though earlier work on the expressive function of the law has focused almost exclusively on the domestic context. ${ }^{222}$ Situated in opposition to the dominant focus on law's

220. For example, my examination of the years in which the Fair Trial coding changed by two points or more from the previous year reveals that the most common easily discernable reason for changes in ratings is a change in government, usually from democracy to nondemocracy or vice versa.

221. See Ann Seidman \& Robert B. SeIdman, State and LaW in the Development PROCESS 145-69 (1994) (describing the "rise of the bureaucratic bourgeoisie").

222. See, e.g., Elizabeth S. Anderson \& Richard H. Pildes, Expressive Theories of Law: A General Restatement, 148 U. PA. L. REv. 1503 (2000); Robert Cooter, Do Good Laws Make Good Citizens? An Economic Analysis of Internalized Norms, 86 VA. L. REV. 1577, 1593-94 (2000); Robert Cooter, Expressive Law and Economics, 27 J. LEGAL STUD. 585 (1998); Dan H. Kahan, What Do Alternative Sanctions Mean?, 63 U. CHI. L. REV. 591,597 (1996); Lawrence Lessig, The Regulation of Social Meaning, 62 U. CHI. L. REv. 943 (1995); Jason Mazzone, When Courts Speak: Social Capital and Law's Expressive Function, 49 SYRACUSE L. REV. 1039 (1999); Richard H. McAdams, A Focal Point Theory of Expressive Law, 86 VA. L. REV. 1649 (2000); Richard H. Pildes, Why Rights Are Not Trumps: Social Meanings, Expressive Harms, and Constitutionalism, 27 J. LegAl Stud. 725 (1998); Paul H. Robinson \& John M. Darley, The Utility of Desert, 91 Nw. U. L. Rev. 453, 471-73 (1997); Cass R. Sunstein, On the Expressive Function of Law, 144 U. PA. L. REV. 2021, 2022 (1996); see also ElIZABETH ANDERSON, VALUE IN ETHICS AND ECONOMICS 33-37 (1993) (discussing expressive norms); H.L.A. HART, PUNISHMENT AND RESPONSIBILITY (1968) (arguing that one of the functions of criminal law is to express social judgments); ROBERT NOZICK, THE NATURE OF RATIONALITY 26-35 (1993) 
sanctioning function, much of this work is aimed at demonstrating that law influences behavior not only by threatening to sanction undesirable actions, but also by what it says. ${ }^{223}$ Broadly speaking, it argues that the social meanings of state action are little recognized but in some cases as important as the action's material impact. ${ }^{224}$ The most widely discussed form of legal expressive theory thus tells actors (particularly state actors) to act in ways that "express appropriate attitudes toward various substantive values." 225

Although the work of these scholars forms part of the backdrop for this Article, the conception here of the expressive function of the law is distinct, largely because this Article focuses on the international rather than domestic context. Unlike in the domestic context, in the international realm only the parties who voluntarily accede to the laws are bound to abide by them (with the notable exception, of course, of customary law, which is not the focus of this Article). As a consequence, the expressive role of the law takes on political dimensions not at issue in the domestic legal context.

The expressive role of treaties described in this Article has two aspects, the first arising from treaties' legal nature and the second from their political nature. Treaties, like domestic laws, work by expressing the position of the community of nations as to what conduct is and is not acceptable; they tell the international community what are the norms and code of conduct of civilized nations. ${ }^{226}$ Yet treaties also have an expressive function that arises from what membership in a treaty regime says about the parties to the treaties. When a country joins a human rights treaty, it engages in what might be called "position taking," defined here as the public enunciation of a statement on anything likely to be of interest to domestic or international actors. ${ }^{227}$ In this sense, the ratification of a treaty functions much as a roll-call vote in the U.S. Congress or a speech in favor of the temperance movement, as a pleasing statement not necessarily intended to have any real effect on outcomes. ${ }^{228}$ It declares to the world that

(discussing the "symbolic utility" that arises out of symbolic meaning); Matthew D. Adler, Expressive Theories of Law: A Skeptical Overview, 148 U. PA. L. REV. 1363 (2000) (providing a critique of some variants of expressive theory); Jean Hampton, An Expressive Theory of Retribution, in RETRIBUTIVISM AND ITS CRITICS 1 (Wesley Cragg ed., 1992) (discussing an expressive theory of retribution).

223. McAdams, supra note 222, at 1650-51.

224. See, e.g., Pildes, supra note 222 , at 762.

225. Anderson \& Pildes, supra note 222, at 1504.

226. This aspect of the expressive function is similar to the broad conception of the expressive function of law outlined by Cass Sunstein. See Sunstein, supra note 222, at 2024-25 ("In this Article I explore the expressive function of law-the function of law in "making statements' as opposed to controlling behavior directly. I do so by focusing on the particular issue of how legal "statements' might be designed to change social norms.").

227. This is a very slight twist on the definition of the term used by David Mayhew. See DAVID R. MAYHEW, CONGRESS: THE ELECTORAL CONNECTION 61 (1974).

228. See Joseph R. GuSFIELd, SYMBolic Crusade: Status POlitics and the AMERICAN TEMPERANCE MOVEMENT (1963); MAYHEW, supra note 227, at 61-73 (discussing the phenomenon of "position taking" in the U.S. Congress). 
the principles outlined in the treaty are consistent with the ratifying government's commitment to human rights.

I focus primarily in this Article on the second aspect of the expressive function because I believe it best helps to explain the empirical findings of my analyses. I do not mean in focusing on the second expressive aspect of treaties to suggest that the first is unimportant; indeed, as I discuss in more detail in the Conclusion, the first expressive function of treaties may change discourse about and expectations regarding country practices and thereby change practices of countries regardless of whether they ratify the treaties.

If the first step to explaining patterns of country treaty compliance is to recognize the expressive role of treaties, the second is to note that this expressive function can work either in unison with or in opposition to the instrumental role of the treaty. When a country is genuinely committed to the goals of the treaty and wishes to see them put into place, the country's expression in joining and remaining a party to a treaty is entirely consistent with its intended course of action: The country both signals support for the treaty's requirements and actually intends to act in ways consistent with those requirements. Treaties that include substantial monitoring or enforcement mechanisms embody some guarantees that the expressive and instrumental roles of the treaty will operate in tandem. For example, a country is unlikely to ratify a free trade agreement and then fail to abide by the terms of that agreement, because failure to abide by the terms of the agreement would likely be detected and lead to retaliatory action. For similar reasons, a country is unlikely to ratify a security pact or a treaty governing the use of airspace or the sea and then fail to abide by its terms. To the extent that monitoring and enforcement are effective, the expression of the commitment to the goals of such treaties is largely indivisible from the act of complying with the terms of the treaties.

But the expressive and instrumental roles of treaties do not always operate this seamlessly. When monitoring and enforcement of treaties is minimal, the expressive and instrumental roles may cease to cohere, and the expressive aspect of the treaty may become divorced from the instrumental aspect. Under such circumstances, a country may express a commitment to the goals of the treaty by joining it, yet fail to meet its requirements. Where there is little monitoring, noncompliance is not likely to be exposed. Therefore, the countries that join the treaty will enjoy the expressive benefits of joining the treaty, regardless of whether they actually comply with the treaty's requirements. ${ }^{229}$ And where there is little enforcement, the costs of membership are also small, as countries with policies that do not adhere to the requirements of the treaty are unlikely to be penalized.

229. The threat, even if small, that a country's noncompliance may be exposed may be of greater significance to some countries than to others. See infra note 256 and accompanying text. 
Where there is a disjuncture between expressive benefits and instrumental goals, it is possible that the expressive aspect of treaties will serve to relieve pressure for real change in performance in countries that ratify the treaty. Because such treaties offer rewards "for positions rather than for effects," ${ }^{230}$ countries can and will take positions to which they do not subsequently conform and benefit from doing so. This is particularly true of treaties enacted for the direct benefit neither of the joining parties nor of those pushing for enactment, but rather of uninvolved third parties. In this sense, human rights treaties can take on the character of "charitable" enactments that are "designed to benefit people other than the ones whose gratification is the payment for passage," and which, as a result, often suffer from indifferent enforcement and have little impact. ${ }^{231}$

There is arguably no area of international law in which the disjuncture between the expressive and instrumental aspects of a treaty is more evident than human rights. Monitoring and enforcement of human rights treaty obligations are often minimal, thereby making it difficult to give the lie to a country's expression of commitment to the goals of a treaty. The strongest means of treaty enforcement-military intervention and economic sanctions-are used relatively infrequently to enforce human rights norms ${ }^{232}$ in no small part because there is little incentive for individual states to take on the burden of engaging in such enforcement activity. ${ }^{233}$ Because of the infrequency with which the international community resorts to such means of enforcement, the threat of their use does not contribute meaningfully to day-to-day compliance with the multitude of human rights treaties. ${ }^{234}$ Moreover, as Louis Henkin puts it, "the principal element of horizontal deterrence is missing" in the area of human rights: "[T]he threat that 'if you violate the human rights of your inhabitants, we will violate the human rights of our inhabitants' hardly serves as a deterrent." 235

230. MAYHEW, supra note 227, at 132. Again, David Mayhew is speaking here of the U.S. Congress, rather than the international treaty system, but the insight is nonetheless instructive.

231. Id. at 132-33. This, Mayhew claims, helps explain why the early Civil Rights Acts of 1957 and 1960, which benefited nonvoting Southern blacks but were passed to please Northern audiences, achieved little progress. $I d$. at 133 . Mayhew notes that the same cannot be said for the Civil Rights Acts of 1964 and 1965. See id. at 133 n.106.

232. See supra note 53 and accompanying text.

233. See Henkin, supra note 48 , at 253 . Henkin states:

[T] he real beneficiaries [of human rights obligations] are not the State promisees but the inhabitants of the promisor State, and, in general, States-even if they have adhered to international agreements--do not have a strong interest in human rights generally, and are not yet politically acclimated and habituated to responding to violations of rights of persons abroad other than their own nationals.

Id. (citation omitted).

234. That is not to say that they play no role in improving human rights. $C f$. Sarah $\mathrm{H}$. Cleveland, Norm Internalization and U.S. Economic Sanctions, 26 YALE J. INT'L L. 1, 5 (2001) (arguing that "[e]conomic sanctions are an important weapon in transnational efforts to promote respect for fundamental rights and can have substantial behavior-modifying potential").

235. Henkin, supra note 48 , at 253. 
Consequently, most human rights treaties rely not on sanctions to encourage compliance but instead on treaty-based and charter-based organs dedicated to monitoring compliance with particular treaties or particular sets of treaties, often through a system of self-reporting. ${ }^{236}$ Were these monitoring systems effective, it is possible that the threat to reputation that they could pose to noncomplying countries would be sufficient to keep noncompliance at low levels. Yet most of these systems have proven woefully inadequate, with countries regularly and repeatedly failing to meet minimal procedural requirements with no repercussions. ${ }^{237}$ Indeed, although treaties often require countries that join them to submit to semi-regular scrutiny by a treaty body, there is no real penalty for failure to participate in this process or for obeying the letter but not the spirit of the treaty requirements. ${ }^{238}$ As a consequence, the failure of a country to comply with its treaty obligations is, in most cases, unlikely to be revealed and examined except by already overtaxed NGOs. ${ }^{239}$

At the same time, at least since World War II, there has been a great deal of pressure on countries to exhibit a commitment to human rights norms. Indeed, human rights treaties are a paradigmatic example of a charitable enactment in the international context. The audience of the decision to ratify human rights treaties is usually not the beneficiary of the agreement-the abused, oppressed, and suppressed of the world-but instead the political and economic actors located for the most part in wealthy liberal nations. Some of these actors, including various NGOs and

236. For clear descriptions and assessments of the intergovernmental human rights enforcement system, see INTERNATIONAL. HUMAN RIGHTS IN CONTEXT, supra note 101, at 592704; and THE UNITED NATIONS AND HUMAN RIGHTS (Philip Alston ed., 1992).

237. See supra note 101 .

238. Comm. on Int'l Human Rights Law \& Practice, First Report of the Committee, in INT'L LAW ASS' N, REPORT OF THE SixTY-SEVENTH CONFERENCE HELd AT HELSINKI, FINLAND 336 (James Crawford \& Michael Byers eds., 1996) (identifying the major deficiencies in the human rights treaty system and issuing recommendations for improving it); Rudolf Geiger, The Violation of Reporting Obligations and the General Rules of State Responsibility, in THE MONITORING SYSTEM OF HUMAN RIGHTS TREATY OBLigations 139, 139 (Eckart Klein ed., 1996) ("The rules of procedure of the treaty bodies provide for certain steps to be taken in order to induce a State to comply with its reporting duty. Such procedural steps may consist of a formal reminder by the treaty organ to the dilatory State or of a report to a superior organ (like the ECOSOC or the UN General Assembly). There are, however, no provisions covering the case should these measures fail."). For an excellent overview of many of the central debates regarding human rights treaty monitoring, see THE FUTURE OF UN HUMAN RJGHTS TREATY MONITORING (Philip Alston \& James Crawford eds., 2000). See also PATRICK JAMES FloOD, ThE EFFECTIVENESS of UN HUMAN RIGHTS INSTITUTIONS (1998) (describing and assessing the UN human rights system); HOWARD TOLLEY, JR., THE UN COMMISSION ON HUMAN RIGHTS (1987) (offering a history and assessment of the UN Commission on Human Rights).

239. Addressing this problem is a central mission of Amnesty International, Human Rights Watch, and the Lawyers Committee for Human Rights. Yet even together, they cannot monitor country compliance with each and every human rights treaty, nor do they attempt to do so. For more on fact-finding functions of international monitors, see INTERNATIONAL HUMAN RIGHTS IN CONTEXT, supra note 101, at 602-10; and THE UN HUMAN RIGHTS SYSTEM IN THE 21 ST CENTURY 63-136 (Anne F. Bayefsky ed., 2000). 
other domestic and international organizations, are genuinely committed to the ends of the treaties but have restricted access to information regarding the real impact of the treaties in individual countries. Others, including potential investors and perhaps nations wishing to provide aid assistance or to deepen economic or political ties, may be less genuinely committed to the ends of the treaties. They may instead be seeking evidence of commitment to the norms embedded in the human rights treaties that they can in turn use to placate more genuinely interested parties to which they must answer (including stockholders and customers of companies wishing to invest in the country and constituents of governments that wish to provide aid to or engage in deeper political or economic ties with the ratifying countries). ${ }^{240}$ Countries that are parties to the treaties can therefore enjoy the benefits of ratification without actually supplying the human rights protections to which they have committed. ${ }^{241}$ Consequently, treaty ratification may become a substitute for, rather than a spur to, real improvement in human rights practices. ${ }^{242}$

In arguing that the expressive and instrumental aspects of human rights treaties are divorced, I am not claiming that countries that ratify human rights treaties necessarily do not conform their actions to the requirements of the treaties. Although actions need not match expressions, this does not mean that they always do not. Moral norms are surely an important force for state and individual action, and human rights scholars are right to focus much of their attention on understanding the source of the ideological appeal of human rights. ${ }^{243}$ Sincere commitment to a human rights treaty

240. Of course, the opposite may be true. It is possible that governments or members of governments that wish to resist deeper trade or political relationships with nations suspected of engaging in human rights violations may use a poor human rights record as an excuse for resisting deeper engagement.

241. This argument parallels that made by Mayhew regarding the U.S. Congress: "If the gratified receive muddled feedback on programmatic accomplishment, the actual supplying of the prescribed benefits becomes a distinctly secondary congressional concern." MAYHEW, supra note 227, at 132. Mayhew, in turn, was strongly influenced by GORDON TULLOCK, Information Without Profit, in PAPERS ON Non-MARKET DECISION-MAKING 141 (Gordon Tullock ed., 1967).

242. In this sense, human rights treaties might be viewed as an example of the claim by Giulio M. Gallarotti that international organization (IO) can lead to adverse substitution. He explains:

Nations are continually faced with difficult domestic and international problems whose resolution entails political, economic, or social costs. Although IO can alleviate shortrun pressures and provide nations with an "out" from more costly solutions, doing so can be counterproductive in that it discourages nations from seeking more substantive and longer-term resolutions to their problems.

Giulio M. Gallarotti, The Limits of International Organizations: Systemic Failure in the Management of International Relations, 45 INr'L ORG. 198, 199 (1991). Gallarotti notes as support for this contention a statement by Secretary-General Pérez de Cuéllar that " [ $t$ ]here is a tendency in the United Nations for governments to act as though passage of a resolution absolved them from further responsibility for the subject in question." Id. at 200 (quoting Pérez de Cuéllar).

243. Some scholars look to moral psychology, arguing that human rights ideals are intuitively attractive to human beings and recognized worldwide as valid. MARGARET E. KECK \& KATHRYN SIKKINK, ACTIVISTS BEYOND BORDERS: ADVOCACY NETWORKS IN INTERNATIONAL POLITICS 
may also arise out of somewhat less idealistic motives. Governments may see a treaty as a relatively costless means of spreading their ideals and principles to other nations. They may hope that the addition of another party to the treaty will build momentum for the formation of new customary law. They might even join the treaty with an eye to constraining their successors, who may or may not share their commitment to human rights, accepting constraints on their powers in the present in order to gain protection from oppressive behavior if they lose power in the future. ${ }^{244}$ More generally, they may seek to use international commitments, including treaty ratifications, to gain political advantage at the domestic level in what may be termed a "reverse two-level game." 245

Even when a country ratifies a treaty and subsequently fails to comply with its terms, it is not necessarily the case that the ratification was disingenuous. Countries may choose to ratify treaties with which they are not already in compliance because they genuinely aspire to improve their practices and they wish to invite international scrutiny of their progress. The practices of such countries may fail to improve for any number of reasons. Those at higher levels of government who are responsible for the ratification may find it difficult to effect change in the actions and decisions of those who actually engage in the violations, including police officers, members of the military, and other low-level state actors. ${ }^{246}$ Indeed, this may help explain the often perverse results for my analyses of countries' torture practices-governments may simply find themselves unable to persuade police officers and members of the military to abandon the use of torture. It is also possible that the ratification may take place in the context of a divided government, with one arm of government joining the treaty

(1998); Sikkink, supra note 83. Others argue that cultural homogeneity is an important source of human rights agreements because states that share a common history, religion, cultural tradition, and values are more likely to agree upon human rights provisions. PAul SIEGHART, THE INTERNATIONAL LAW OF HUMAN RIGHTS 26-27 (1983); Nisuke Ando, The Future of Monitoring Bodies-Limitations and Possibilities of the Human Rights Committee, in CANADIAN HUMAN RIGHTS YEARBOOK 1991-1992, at 169, 171-72 (1992); Jack Donnelly, International Human Rights: A Regime Analysis, 40 INT'L ORG. 599, 638 (1986). Yet others offer historical explanations for the appeal of human rights. ANDREW DRZEMCZEWSKI, EUROPEAN HUMAN RIGHTS CONVENTION IN DOMESTIC LAW 220 (1983); John H. Whitfield, How the Working Organs of the European Convention Have Elevated the Individual to the Level of Subject of International Law, 12 ILSA J. INT'L L. 27, 31 (1988). Regardless of the source to which they point, however, they all agree on one fundamental point: Human rights have an appeal that generates genuine commitment.

244. See Moravcsik, supra note 25.

245. This would entail something of a reversal of the relationship described by Robert $D$. Putnam in his seminal article, Robert D. Putnam, Diplomacy and Domestic Politics: The Logic of Two-Level Games, 42 INT'L ORG. 427 (1988). This reversal is further explored in my work in progress on human rights treaty formation. See Hathaway, supra note 68.

246. A.W. Brian Simpson points to this difficulty in the context of British compliance with the European Convention on Human Rights. See SIMPSON, supra note 9. 
with a true desire to meet its terms but the other refusing to implement the changes required to follow through on the commitment.

The argument presented here therefore does not hinge on the assumption that countries will not comply, or do not intend to comply, with a treaty's requirements; rather, it relies on the fact that, for whatever reason, they may fail to do so and are not only unlikely to be sanctioned as a result but are likely to receive an expressive benefit regardless of their actual practices. Indeed, human rights treaties offer countries an expressive benefit precisely because at least some countries that ratify the treaties actually meet their terms. If every country that ratified a human rights treaty thereafter failed to comply with it, ratification of the treaty would likely cease to offer countries any expressive benefit. Because large numbers of countries do actually comply with the terms of the human rights treaties they ratify (as we have seen, countries that ratify human rights treaties do generally have better ratings on average than those that do not), and because it is difficult to determine which countries have met their treaty obligations and which have not, every country that ratifies receives an expressive benefit from the act of ratification, albeit one that is discounted to take into account the possibility that the country will fail to meet the treaty obligations it has accepted. ${ }^{247}$

This argument throws new light on institutional theories of treaty compliance. As noted in Subsection I.A.2, institutional theorists must rely on the indirect sanction of reputational effects of treaties as the primary anchor for human rights treaty compliance for all countries but those for which compliance is costless. ${ }^{248}$ Yet, thus far, institutional scholars have not considered the indirect benefits of treaty ratification-the position-taking and signaling effects discussed above. If countries may obtain reputational benefits from ratifying some treaties while suffering little reputational cost from failing to observe the obligations assumed, countries may be substantially more likely to fail to comply with their treaty obligations. Indeed, it is possible that the expressive benefit of a treaty is at its greatest for precisely those countries not already in compliance with the treatythose countries may have more to gain, and perhaps less to lose, than those with good practices and hence good reputations. ${ }^{249}$ In assuming that

247. This situation is unlike the used car context analyzed in George A. Akerlof, The Market for "Lemons": Qualitative Uncertainty and the Market Mechanism, 84 Q.J. ECON. 488 (1970). Akerlof argued that due to quality uncertainty in the used car market, good used cars may no longer be sold. Id. In the treaty ratification context, however, the cost of the good to the "seller" has an inverse relationship to the quality of the "good." That is, the cost of ratification is likely lower for many of the countries that intend to comply with the requirements of the treaty. Thus, the discounting of the expressive benefit does not lead such countries to stop "selling" the good product (i.e. ratifying the treaties with the intention of actually complying with them).

248. See supra text accompanying notes 52-53.

249. See infra note 256. 
noncompliance will be detected, institutionalists have overestimated the indirect costs of noncompliance in treaties for which monitoring is minimal. As a result, institutional scholars' cost-benefit calculus for treaties that exhibit these characteristics overpredicts compliance. Where joining treaties might be expected to bring reputational benefits and where monitoring of the compliance with those treaties is minimal, institutional theorists ought to adjust their expectations regarding indirect sanctions and benefits accordingly.

Relatedly, the perspective on human rights treaties presented here provides an interesting twist on the claim by Daniel Farber that human rights protection acts as a "signal" that encourages investment in the country. ${ }^{250}$ Farber argues that contrary to Richard Posner's claim that poor countries can ill afford to protect human rights because costly and ambitious legal reforms divert resources from projects more directly linked to economic growth, human rights protection can encourage economic growth. ${ }^{251}$ Human rights protection, Farber explains, requires prioritizing long-term over short-term benefits. ${ }^{252} \mathrm{~A}$ decision by a government to protect human rights thus indicates to investors that the government has a low discount rate and is therefore less likely to engage in expropriation. ${ }^{253}$ Countries that make this signal of human rights protection encourage investment and thereby spur economic growth. But Farber's "rights as signals" argument assumes that the only way in which countries can signal to investors a commitment to human rights is actually to protect and enforce those rights. This does not take into account the problem of imperfect information about country practices, which is especially strong in the area of human rights. Because it is difficult to obtain information about human rights practices, investors are likely to look to obvious and readily discoverable indications of a country's human rights record in considering where to invest. One of these indicators is, as Farber points out, the existence of a constitution. ${ }^{254}$ Another such indicator is membership in the major international and regional human rights treaty regimes, because the fact of ratification is highly public and easy to interpret. Actual protection or enforcement of rights-about which it can be difficult to obtain information-may therefore be less likely to be rewarded than the

250. Daniel A. Farber, Rights as Signals (Nov. 2, 2000) (unpublished manuscript, on file with author).

251. Id. at 1-8.

252. Id. at 15-18.

253. Id. at $23-26$.

254. The adoption of a constitution no more guarantees that the rights defined therein will be enforced than does the adoption of a treaty. Many countries have good laws and constitutions that are not enforced. As Ann and Robert Seidman have spent decades demonstrating, this is not mere coincidence. ANN SEIDMAN ET AL., LEGISLATIVE DRAFTING FOR DEMOCRATIC SOCIAL CHANGE (2001) (providing a guide for legislative drafting that demonstrates how to write enforceable laws). 
expression of a commitment to human rights, an expression that can be effectively made through the simple act of joining a treaty. ${ }^{255}$

The recognition of the dual roles of treaties helps explain the paradoxical findings of my analyses. If the expressive and instrumental roles of human rights treaties are divorced from one another (so that a country can express its willingness to be bound by a treaty by ratifying it and then fail to abide by its requirements) and if there is substantial external pressure on countries to conform to human rights norms, one would expect treaty ratification to be associated with regular noncompliance, which is of course what the evidence suggests. Indeed, because human rights treaties offer countries rewards for positions rather than effects, ratification of treaties can serve to offset pressure for real change in practices. This might help explain why we see evidence of a less linear relationship between human rights practices and treaty ratification than we would expect if the instrumental function of treaties held sway. Countries with worse human rights practices face greater potential costs of joining a treaty to the extent that they expect it to be monitored and enforced. But they also stand to gain more from the expression of adherence to the treaty, particularly where they are under external pressure to exhibit their commitment to human rights norms. At the same time, they may have less reputational capital to lose. If countries with worse human rights practices also have worse reputations for law-abidingness than those with better practices, they may be more willing to join treaties with which they are not certain they will be able to comply. ${ }^{256}$ These cross-cutting pressures may well help account for the results of my analyses: Countries with worse human rights ratings often ratify treaties at higher rates than those with better ratings, and human

255. Signaling arguments generally assume that in order for an act to carry a signaling effect, it must entail real costs. See, e.g., ERIC A. POSNER, LAW AND SOCIAL NORMS 19 (2000) ("Signals reveal type if only the good types, and not the bad types, can afford to send them, and everyone knows this."); Eric A. Posner, The Strategic Basis of Principled Behavior: A Critique of the Incommensurability Thesis, 146 U. PA. L. REV. 1185 (1998) (exploring the difference between actors' public representations and their actual behavior); see also Simmons, supra note 4, at 324 (arguing that states submit to International Monetary Fund obligations as a "signaling device ... to convince private market actors as well as other governments of a serious intent to eschew the proscribed behavior," and thereby obtain "benefits of good standing in the international economic community"). Because I claim that countries that ratify treaties need not intend to carry out the requirements of the treaty, ratification would appear not to meet this condition. Assuming, however, that ratification does entail costs for some actors-those that actually do carry out a treaty's terms-and because it is difficult or impossible to distinguish these actors from those for whom ratification is virtually costless, ratification continues to issue a message, though perhaps not a signal as this literature would usually define it.

256. Conversely, countries with good practices and good reputations may be more reluctant to join treaties with which they are not certain they will be able to comply. Indeed, this may partially explain the United States's reluctance to join international human rights treaties. It may be highly risk-averse to being identified as failing to comply with human rights treaties to which it has committed. This dynamic will be explored further in a work in progress. See Hathaway, supra note 68 . 
rights treaty ratification is often associated with worse ratings than otherwise expected.

In this light, it is also understandable that a perverse relationship between human rights treaties and countries' human rights ratings is sometimes found in more entrenched areas of human rights. The treaties prohibiting genocide and torture, which are nonderogable norms of international law, ${ }^{257}$ impose little additional legal obligation on countries that are parties, because all countries are already bound under customary international law to respect the rights covered in the treaty. Joining these treaties thus entails only acceptance of relatively minimal additional reporting requirements. At the same time, the benefits of making a strong expression of adherence to the treaty norms can be substantial; the government of a country that is under pressure to adhere to international norms can use membership in the relevant treaty regime as evidence of its commitment to abide by the norms the treaty embodies. Because monitoring is imperfect and enforcement often minimal, any gap between expression and action is unlikely to be made public. For these reasons, we expect and indeed find evidence that in entrenched areas of human rights, treaty ratification by individual countries is more likely than in less entrenched areas of human rights to serve as a substitute for actual improvements in human rights practices. ${ }^{258}$

This same dynamic may provide at least a partial explanation for the empirical findings regarding the Optional Protocol to the Covenant of Civil and Political Rights and Article 21 to the Torture Convention. Both of these provisions provide for additional enforcement provisions that are binding only on treaty parties that opt in. The Optional Protocol provides that state parties that accept the Protocol must recognize the competence of the Human Rights Committee to receive and consider communications from other state parties alleging a violation by the state party of any rights set forth in the Convention. ${ }^{259}$ Article 21 to the Torture Convention provides that an acceding state party must recognize the competence of the Committee Against Torture to receive and consider communications from other state parties indicating that it is not fulfilling its obligations under the

257. See sources cited supra note 120.

258. This argument provides an interesting twist on Thomas Franck's claim that "symbolic validation" is an important determinant of legitimacy and hence of whether a law will be met with compliance. See FRANCK, supra note 87, at 34-38. Although the characteristics that indicate symbolic validation-including ritual and pedigree-may lead countries to conform their practices to the principle that is validated, treaties possessing these characteristics are not necessarily more likely to enjoy high rates of compliance. Indeed, the argument of this Article is that the opposite may be true: Countries may be more likely to use such treaties to offset preexisting pressure for change in practices.

259. Optional Protocol, supra note 163, art. 1, 999 U.N.T.S. at 302. 
Convention. ${ }^{260}$ It exhibits nearly identical ratification patterns to Article 22 of the same Convention, which provides for an individual complaint mechanism similar in form to that put into effect in the Optional Protocol. ${ }^{261}$ Although in principle these provisions establish much stronger enforcement mechanisms than the treaties as a whole, in practice they tend not to be particularly effective. Although the Protocol covers over one billion people, current estimates are that the Human Rights Committee can hear only about thirty complaints a year-clearly an insufficient number to establish a meaningful deterrent-and does not have the resources or mandate to follow up reliably and effectively on its recommendations. ${ }^{262}$ Similarly, in the first thirteen years the Torture Convention was in force, the Committee Against Torture received 154 individual complaints, which resulted in thirty-three final views, of which sixteen found violations. ${ }^{263}$ The state-tostate complaint procedure established under Article 21 has yet to be used. ${ }^{264}$

Because the Optional Protocol and Article 21 include somewhat stronger enforcement mechanisms, the expressive and instrumental roles of the provisions are less easily segregated. As a consequence, we would expect less frequent use of the expressive aspect of these provisions by countries that have little intention of complying with their requirements. The empirical evidence seems to bear out this expectation. Although the Optional Protocol and Article 21 are not associated with better ratings for the group of countries as a whole than otherwise expected (the results for these treaty variables are insignificant), they are also not associated with worse ratings. ${ }^{265}$ This result is particularly noteworthy for Article 21, as ratification of the Torture Convention itself is associated with worse ratings ${ }^{266}$ Moreover, the comparison of ratification rates at various levels of human rights ratings demonstrates that noncompliance is lower for these

260. Torture Convention, supra note 51, art. 21 , S. TREATY DoC. No. 100-20, at 26,1465 U.N.T.S. at $118-20$.

261. Id art. 22, S. TREATY DOC. NO. 100-20, at 27, 1465 U.N.T.S. at 120.

262. INTERNATIONAL HUMAN RIGHTS IN CONTEXT, supra note 101, at 740-41 (providing an overview of the current status of the individual complaint procedure under the Optional Protocol and noting that although the Committee had requested follow-up information with respect to the 253 cases in which it had found violations, it had received information with regard to only 152 of these cases); Henry J. Steiner, Individual Claims in a World of Massive Violations: What Role for the Human Rights Committee?, in THE FUTURE OF UN HUMAN RIGHTS TREATY MONITORING, supra note 238, at 15, 33 (noting that the current capacity of the Human Rights Committee offers "slender support for the rule of law").

263. INTERNATIONAL HUMAN RIGHTS IN CONTEXT, supra note 101, at 777.

264. Id. at 776 (noting that no interstate complaint has ever been brought under any of the UN treaty-body procedures).

265. See Table 3, supra Section Il.C. Indeed, ratification of the Optional Protocol by full democracies is associated with better Civil Liberty ratings than expected. See Table 5, supra Scction II.C.

266. See Table 3, supra Section II.C. The evidence is not unambiguously positive, however, as ratification of Article 21 by full democracies is associated with worse Torture ratings than expected. See Table 5, supra Section II.C. 
provisions than for the treaties of which they are a part: Ratification rates among countries with the worst ratings are at or nearly at their lowest levels. ${ }^{267}$

The dual roles of treaties might also help explain what is perhaps the most puzzling of the empirical findings: Ratification of regional human rights treaties is relatively frequently associated with worse human rights ratings than would otherwise be expected. Ratification of regional human rights treaties may be more often and more markedly associated with worse human rights ratings than is ratification of universal human rights treaties because regional political and economic interdependence creates greater incentives for countries to express their commitment to community norms even when they are unable or unwilling to meet those commitments. In the regional context, the need to be an accepted member in what Chayes and Chayes term the "complex web of international arrangements" is particularly strong, as membership brings with it an array of economic and political benefits, and exclusion poses dangers. ${ }^{268}$ For this reason, the sanction for violating regional international norms - the " "exclusion from the network of solidarity and cooperation" "-is particularly threatening. ${ }^{269}$ Indeed, Beth Simmons's finding that governments' compliance with the IMF's Articles of Agreement is positively influenced by the compliance behavior of others in the region suggests that countries care a great deal about the practices and commitments of their neighbors. ${ }^{270}$ Chayes and Chayes fail to note, however, that the threat of alienation may sometimes be soothed not only by actual compliance, but also by relatively toothless expressions of adherence to the relevant norm of international law. Where, as is often the case in the area of human rights, actual changes in practices are extremely costly and difficult to perceive, and treaty ratification is relatively costless and immediately apparent, ratification may be used to offset pressure for real change.

Of course, regional treaties do tend to include stronger enforcement and monitoring mechanisms than do universal treaties, and therefore the expressive and instrumental functions of the treaties should be more difficult to separate. The European Convention on Human Rights and the American Convention on Human Rights both put in place courts that can hold party states that accept the court's jurisdiction accountable for violations of rights established by the treaties, ${ }^{271}$ and the treaties contain

267. See Figures 2-4, supra Section II.B.

268. CHAYES \& CHAYES, supra note 1 , at 27.

269. Id. (quoting ROBERT D. PUTNAM, MAKING DEMOCRACY WORK: CIVIC TRADITIONS IN MODERN ITALY 183 (1993)).

270. See Simmons, supra note 2 , at 832 .

271. See American Convention on Human Rights, supra note 141 , ch. VII, 1144 U.N.T.S. at 157-60 (establishing the Inter-American Court of Human Rights); id. art. 62, 1144 U.N.T.S. at 159 (providing that the Court has jurisdiction only if the state party whose conduct is at issue has 
individual and state-to-state complaint mechanisms (parties to the American Convention must agree separately to the state-to-state complaint mechanisms in order to be subject to them). ${ }^{272}$ Moreover, there are many examples of changes in law or practice by parties to the European Convention in response to decisions by the European Court of Human Rights. ${ }^{273}$

Yet although the regional treaty mechanisms are much stronger than those in the universal treaties, they nonetheless leave substantial room for noncompliance, in part because the strongest features are relatively infrequently used. Indeed, although the regional treaties vary to some degree in the stringency of their enforcement mechanisms, the better predictor of the impact of treaty ratification on practices is the emphasis the regional organization places on strong human rights records as a condition of membership. Although a clean human rights record was only recently made an explicit condition of membership by the European Union, ${ }^{274}$ it has

entered into a special agreement or declared that it recognizes as binding, ipso facto, the jurisdiction of the Court on matters relating to interpretation of the Convention); European Convention on Human Rights, supra note 67, $\S 2,213$ U.N.T.S. at 234 (establishing the European Court of Human Rights).

272. American Convention on Human Rights, supra note 141, art. 45, 1144 U.N.T.S. at 155 (providing that states must make an additional declaration accepting the competence of the Commission to hear allegations by another state party against them); id. art. 44, 1144 U.N.T.S. at 155 (providing that any person or group of persons or any legally recognized nongovernmental entity may lodge a petition with the Commission containing denunciations or complaints of a violation by a state party); European Convention on Human Rights, supra note 67, art. 24, 213 U.N.T.S. at 236 (providing that any party to the Convention may refer to the Commission any alleged breach of the provisions of the Convention by any other party); id. art. 25, 213 U.N.T.S. at 236 (permitting individual applications to the Commission from any person, nongovernmental organization, or group of individuals claiming to be the victim of a violation by a state party).

273. See Robert Blackburn \& Jorg Polakiewicz, Preface to FUNDAMENTAL RIGHTS IN EUROPE: THE EUROPEAN CONVENTION ON HUMAN RighTS AND ITS MEMBER STATES, 19502000, at ix, ix (Robert Blackburn \& Jorg Polakiewicz eds., 2001) (providing a "detailed study of the practical effect of the [European] Convention [on Human Rights] upon and within the domestic legal and governmental systems of thirty-two of its member countries"). Perhaps the best-known example (at least in the United States) of a European Court of Human Rights case that precipitated a change in the domestic policy of a European Union member is Lustig-Prean $v$. United Kingdom, App. No. 31417/96, 29 Eur. H.R. Rep. 548, $572-87$ (1999), which held that the discharge of two British nationals from the Royal Navy on the sole ground that they were homosexual violated Article 8 of the European Convention. Less than a year after the decision was rendered, the U.K. began permitting persons who are openly homosexual to serve in the British Armed Services. See T.R. Reid, British Military Lifts Restrictions on Gays, SUN-SENTINEL (Ft. Lauderdale), Jan. 13, 2000, at 14A.

274. Treaty of Amsterdam Amending the Treaty on European Union, the Treaties Establishing the European Communities and Certain Related Acts, Oct. 2, 1997, 1997 O.J. (C 340) 1 (entered into force May 1, 1999) [hereinafter Amsterdam Treaty]. The Amsterdam Treaty amended the Treaty on European Union Article 49 (formerly Article O) to require new member states to demonstrate respect for the principles of Article 6(1) of the Treaty on European Union in order to accede to the Union. See Treaty on European Union, Oct. 2, 1997, art. 49, 1997 O.J. (C 340) 145 [hereinafter Treaty on European Union]. The Amsterdam Treaty also amended the Treaty on European Union to establish a procedure whereby some membership rights in the EU can be suspended if a "serious and persistent breach" of human rights is found in a member state. Treaty on European Union, supra, art. 7, 1997 O.J. (C 340) at 154. 
been an implicit membership issue for the EU at least since the 1970 s. $^{275}$ It is also a condition of membership for the Council of Europe. ${ }^{276}$ Membership in the OAS is open to all nation-states in the Americas, ${ }^{277}$ but joining the organization requires signing the Charter of the OAS, which carries with it an ill-defined but nonetheless binding obligation not to violate the human rights of one's own nationals. ${ }^{278}$ By contrast, the Charter of the Organization of African Unity makes virtually no mention of human rights, nor is the human rights record of a country relevant to membership. ${ }^{279}$ Although the African Charter on Human Rights has much weaker enforcement mechanisms than its European and American counterparts,

275. See GeOrge A. BERMANN ET AL., EUROPEAN UNION LAW (2d ed. forthcoming 2002) (manuscript at 252, on file with author) (noting that in 1993, the European Council decided at Copenhagen that "membership requires that the candidate country has achieved stability of institutions guaranteeing democracy, the rule of law, human rights and respect for and protection of minorities"); Andrew Williams, Enlargement of the Union and Human Rights Conditionality: A Policy of Distinction?, 25 EUR. L. REV. 601, 602 (2000) ("Prior to . . the 1980s, there was little evidence of an explicit human rights conditionality applied to potential members of the European Union. However, as entry was possible only through the unanimous approval of all the existing Member States, it was perhaps clear that any applicant for membership had to ascribe to the fundamental principles of the Union which since at least the early 1970s had included respect for human rights." (footnotes omitted)). For example, Turkey's bid to join the EU was rejected in 1997, in part because of its poor human rights record. See Stephen Kinzer, Europeans Shut the Door on Turkey's Membership in Union, N.Y. TIMES, Mar. 27, 1997, at A13 (quoting the German Foreign Minister as stating that Turkey did not qualify for membership because of its record on "human rights, the Kurdish question, relations with Greece and of course very clear economic questions"). Indeed, since 1998, the European Commission has begun producing reports on the progress of applicant nations toward accession in which they detail, among other things, the human rights records of the applicants. Tellingly, the section of the report that covers human rights always begins with an overview of the human rights treaties that the applicant country has ratified. It then details relevant changes in the country in the last year, focusing largely on legal changes and less on actual state practices. See Comm'n on Progress Towards Accession, Progress Reports (Oct. 13, 1999), at http://europa.eu.int/comm/enlargement/report_10_99/index.htm.

276. The Statute of the Council of Europe now effectively requires states to ratify the European Convention on Human Rights as a condition of membership in the Council. The Statute of the Council of Europe provides that "[e]very Member of the Council of Europe must accept the principles of the rule of law and the enjoyment by all persons within its jurisdiction of human rights and fundamental freedoms." Statute of the Council of Europe, May 5, 1949, art. 3, 87 U.N.T.S. 103, 106. Accession to the Council therefore may often require countries to enact legislative changes (for example, abolish the death penalty) and satisfy experts operating on behalf of the Council that the country meets minimum human rights standards.

277. See Charter of the Organization of American States, as Amended by the Protocols of Buenos Aires and Cartagena De Indias; the Protocol of Amendment of Washington; and the Protocol of Amendment of Managua, June 10, 1993, art. 4, S. TREATY DOC. NO. 103-22 (1994), 33 I.L.M. 981, 990 ("All American States that ratify the present Charter are Members of the Organization.").

278. See id. art. 3, \& k, 33 I.L.M. at 990 ("The American States proclaim the fundamental rights of the individual without distinction as to race, nationality, creed, or sex." ); $i d$. art. $3, \S \mathrm{i}, 33$ I.L.M. at 990 ("Social justice and social security are bases of lasting peace."); id. art. 44, 33 I.L.M. at 994 (enumerating various human rights that member states are expected to observe and respect); Thomas Buergenthal et al., Protecting Human Rights in the Americas 26 (1982).

279. See Charter of the Organization of African Unity, May 25, 1963, 479 U.N.T.S. 39 (making virtually no mention of human rights); id. arts. I, IV, 479 U.N.T.S. at 72,74 (stating that membership in the OAU is open to all “independent sovereign African State[s]”). 
ratification of the Charter is less often associated with worse human rights ratings than would otherwise be expected. ${ }^{280}$ Thus, it is possible that the heightened external pressure to demonstrate adherence to human rights norms that is found in the regional context, especially in Europe and to a lesser extent in the Americas, leads nations to join regional human rights treaties at higher rates even when they do not intend, or are unable, to implement them fully, despite those treaties' stronger enforcement and monitoring provisions. Moreover, ratification of regional treaties may cause a significant lessening of external human rights-related pressure, thereby leading ratifying countries to make fewer real improvements in their practices than they might otherwise have made.

Finally, the theory helps us understand why democracies that have ratified human rights treaties may be more likely to have better practices than would otherwise be expected and less likely to engage in large numbers of human rights violations if they have ratified the relevant human rights treaty. The theory developed here portrays states as sometimes willing to view treaty ratification as an expressive tool that does not necessarily entail an intention to abide by a treaty's requirements. Such disingenuousness is, however, less likely in democracies, not only because democracies are arguably more likely to have a true normative commitment to the principles embedded in the treaties but also because democratic governments will likely find it difficult to engage in expressions that are inconsistent with their actions. This helps place the liberalist claims that democracies are more likely to abide by their treaty commitments in a broader context. As liberalists note ${ }^{281}$ liberal democracies contain powerful domestic interest groups that mobilize to pressure their governments to comply with their international legal obligations. In countries with an independent court system, the courts may also offer a forum for those seeking to obtain enforcement of treaty commitments. And the independent news organizations found in most such democracies can divine and expose failures of a government to meet its obligations, thus reducing any expressive benefits to be gained from insincere ratification of a treaty. Hence, democracies in general have a more difficult time divorcing the expressive function of treaties from the instrumental, and are therefore less likely to exhibit high rates of noncompliance when they have ratified a treaty. ${ }^{282}$

280. See Table 4, supra Section II.C.

281. See supra text accompanying notes 61-65.

282. One might hypothesize that democracies are less likely to ratify treaties and then fail to comply with them because democracies are simply less likely to ratify treaties in general, largely because democratic institutions create significant barriers to ratification. The assumption upon which this hypothesis rests, however, may not be entirely accurate: As Figures 1-5, supra Section II.B, demonstrate, democracies are oflen more, rather than less, likely to ratify human rights treaties than the group of countries as a whole. 
In sum, treaties shape behavior not simply by influencing tangible benefits and not simply because they create legitimate legal obligations, but also by providing nations with a powerful expressive tool. Where, as is usually the case in the area of human rights, there is little monitoring or enforcement, combined with strong pressure to comply with norms that are embodied in treaty instruments, treaty ratification can serve to offset, rather than enhance, pressure for real change in practices. Only by recognizing that treaties operate on an expressive as well as on an instrumental level can we fully understand observed compliance.

\section{LOOKING AHEAD: CAN TREATIES MAKe A DifFERENCE?}

Understanding the dual nature of human rights treaties can help us better understand the relationship between human rights treaty ratification and human rights practices. External pressure on countries to demonstrate a commitment to human rights norms creates strong incentives for countries to engage in favorable expressive behavior by ratifying human rights treaties. But because human rights treaties are generally only minimally monitored and enforced, there is little incentive for ratifying countries to make the costly changes in actual policy that would be necessary to meet their treaty commitments. Given this, it is perhaps not so surprising that we find the patterns we do in the empirical analysis. Ratifying a human rights treaty can relieve pressure for change imposed by international actors, who may rely more heavily on positions than effects in evaluating countries' records. This reduction in pressure may in turn lead a country that ratifies to improve its practices less than it otherwise might. This dynamic may be stronger in the regional context because regional political and economic interdependence generates greater external pressure on countries to exhibit a commitment to human rights norms. When countries ratify regional treaties, therefore, the falloff in external pressure for real improvement in practices may be greater and the reduction in the pace of real improvement may consequently also be greater. Finally, the strongest democracies may be more likely to adhere to their treaty obligations because the existence of internal monitors makes it more difficult for such countries to conceal a dissonance between their expressive and actual behavior or because liberal democracies have a true normative commitment to the aspirations embedded in the human rights treaties.

What does all this imply about the future of human rights treaties? We must not jump to conclusions about the worth of human rights treaties based solely on the quantitative analysis above. Even if accurate, the results do not preclude the possibility that human rights treaties have a favorable impact on human rights. Although countries that ratify human rights treaties on the whole appear not to have better human rights practices than would 
otherwise be expected, treaties may have broader positive effects not captured by the analysis. Treaties may lead to more aggressive enforcement by UN Charter-based bodies, which may take action against ratifiers and nonratifiers alike. And human rights treaties and the process that surrounds their creation and maintenance may have a widespread effect on the practices of all nations by changing the discourse about and expectations regarding those rights. The expressive function of treaties, after all, has two aspects: It expresses the position both of the individual nation-state and of the community of nations with regard to the subject of the treaty. Although the individual expression need not be consistent with the intentions of the country to put the requirements of the treaty into effect, the collective expression of a series of countries may have genuine effect. Indeed, when a treaty gains a sufficient following, it is generally viewed as expressing what conduct is and is not acceptable to the community of nations. The treaty can thus influence individual countries' perceptions of what constitutes acceptable behavior. ${ }^{283}$

What is important to note- and the reason that this effect would not be detected in the empirical analysis-is that this influence can be felt by countries regardless of whether they ratify the treaty or not. All countries, having received the message transmitted by the creation and widespread adoption of a treaty, are arguably more likely to improve their practices or at least less likely to worsen them than they would otherwise have been. Anecdotal evidence lends support to this view, as observance of the norms embodied in many human rights treaties has come to be seen as an important facet of good international citizenship in the post-World War II period. It is worth noting, however, that the empirical analysis does not offer support for this intuition. ${ }^{284}$ Net of other factors that seem to have improved human rights practices over time, the general direction of change in countries' human rights ratings during the time period analyzed, as measured by the trend variable, does not show consistent upward movement across all the areas of human rights, much less consistent statistically significant upward movement. Whether treaties have generally favorable effects on practices therefore remains an important subject for further research and analysis.

In addition to this broader positive expressive effect, it is also possible that ratification of human rights treaties has an undetected long-term

283. Cassel posits a similar process. See Cassel, Does International Human Rights Law Make a Difference?, supra note 2, at 122 ("Over time, the extent to which international law serves as a useful tool for protection of human rights will depend mainly on its contribution to a broader set of transnational processes that affect the ways people think and institutions behave ....").

284. This may be true in part because the data on practices rarely predate the opening of the relevant treaties for signature. If the creation of human rights treaties has a positive impact on discourse, this impact is probably concentrated in the years immediately before and perhaps immediately after they open for signature, years that the data set may not cover. 
positive effect on individual ratifying countries as well. When a country ratifies a treaty, it may do so for purely disingenuous reasons (simply to gain the expressive benefit), for aspirational reasons (because the government or a part thereof is truly committed to the norms embodied in the treaty and wishes to commit the country thereto), or for self-interested reasons (perhaps because political or economic benefits are tied to ratification). Even where ratification of the treaty is not motivated by commitment to the norms embodied in the treaty, the act of ratification and the continued fact of membership in the treaty regime may also serve to slowly transform the country's practices as it gradually internalizes the norms expressed. Indeed, ratification creates an opportunity for those Harold Koh terms "norm entrepreneurs" to begin to provoke interactions aimed at gradual internalization of the norms embodied in the treaty ${ }^{285}$ Yet this process can take decades to lead to tangible change. Because most of my analyses rely on data that cover fewer than two decades, it is possible that I have simply not studied a long enough period to detect this type of long-term change. Or perhaps the reduction in external pressure for improvement that may result from a country's ratification of a treaty initially offsets any gains that may be made through the gradual process of internalization that ratification may set in motion. Or perhaps this positive influence of treaty ratification occurs alongside the negative expressive effect, thus leading to little or no net effect from treaty ratification-which is, indeed, the predominant finding of the quantitative analyses described in Part II. Again, this remains an important subject for future study.

Whatever the outcome of these inquiries, to the extent that noncompliance with many human rights treaties is commonplace, the current treaty system may create opportunities for countries to use treaty ratification to displace pressure for real change in practices. This is a problem that should be addressed. One obvious step toward improvement would be to enhance the monitoring of human rights treaty commitments, the current weakness of which may make it possible for the expressive and instrumental roles of the treaties to work at cross-purposes. ${ }^{286}$ Although there is some public information on countries' human rights practicesindeed, that information forms the basis for this study-it is not specifically

285. See Koh, Bringing International Law Home, supra note 102, at 642-63, 646 (discussing the role of norm entrepreneurs in the process of internalization); see also Cassel, Does International Human Rights Law Make a Difference?, supra note 2, at 122 ("International human rights law also facilitates international and transnational processes that reinforce, stimulate, and monitor these domestic dialogues."); Thomas Risse \& Kathryn Sikkink, The Socialization of International Human Rights Norms into Domestic Practices: Introduction, in THE POWER OF HUMAN RIGHTS, supra note 9, at 1, 5 (arguing that transnational advocacy networks "empower and legitimate the claims of domestic opposition groups against norm-violating governments").

286. For an interesting examination of monitoring of international treaties, see ADMINISTRATIVE AND EXPERT MONITORING OF INTERNATIONAL TREATIES (Paul C. Szasz ed., 1999). 
aimed at evaluating compliance with human rights treaty obligations nor is it, as a general matter, well publicized. If failures to live up to treaty commitments were more regularly and widely exposed, it would be costly for countries to express a commitment to human rights norms without actually meeting their treaty obligations. Greater exposure of noncompliance could be achieved in part by further enhancing the roles of existing NGOs. But a comprehensive monitoring system cannot be supplied solely by private organizations, which can do little in the face of the refusal of states to assist or cooperate with their efforts. Revisions of the existing treaty system aimed at exposing and publicizing noncompliance are needed if the reputational costs of noncompliance are truly to be enhanced.

The main method of enforcement and monitoring under the major universal treaties is a largely voluntary system of self-reporting. The bodies cannot assess any real penalties when countries fail to comply with reporting requirements, and these bodies possess insufficient resources to give complete and critical consideration to the reports that are made. ${ }^{287}$ At a minimum, therefore, revisions aimed at strengthening the self-reporting system should be considered. ${ }^{288}$ Although the specific shape of the reforms can be debated, a few changes are clearly in order.

To begin with, bodies charged with implementing the treaties should be empowered to compel countries to participate in the reporting and monitoring systems to which they have subscribed. These bodies should include independent experts charged with scrutinizing state practices and empowered to engage in independent investigation and fact-gathering regarding relevant state activity. The bodies should provide NGOs with more regular opportunities to participate in the process of evaluating and assessing state practices. Moreover, they ought to make a greater effort to encourage publicity of their conclusions by improving press access and by making available to news organizations information that is readily understood by nonspecialists. Effective follow-up procedures should be in place to assess and assist countries' efforts to improve compliance. More fundamentally, future human rights treaties should be written with a closer eye to effective monitoring. Declarations of rights that are not easily defined and measured, or that are not accompanied by an effective plan for securing true remedies for violations of those rights, may actually be counterproductive.

287. See supra note 101 .

288. See, e.g., BAYEFSKY, supra note 101 (examining ways to improve the UN reporting system, in an exhaustive report on the UN human rights treaty system); THE FUTURE OF UN HUMAN RIGHTS TREATY MONITORING, supra note 238; Alston, supra note 101, 9I 37-79; Dinah Po Kempner, Making Treaty Bodies Work: An Activist Perspective, in AM. SOC'Y OF INT'L LAW, supra note 2, at $\mathbf{4 7 5}$ (making similar proposals for reform to the UN human rights treaty system from an activist's perspective). 
The findings of this study may also give reason to reassess the current policy of the United Nations of promoting universal ratification of the major human rights treaties. ${ }^{289}$ Although universal ratification of a treaty can make a strong statement to the international community that the activity covered by the treaty is unacceptable, pressure to ratify, if not followed by strong enforcement and monitoring of treaty commitments, may be counterproductive. Indeed, it may be worthwhile to develop, consider, and debate more radical approaches to improving human rights through the use of new types of treaty membership policies. If countries gain some expressive benefit from ratifying human rights treaties, perhaps this benefit ought to be less easily obtained. Countries might, for example, be required to demonstrate compliance with certain human rights standards before being allowed to join a human rights treaty. ${ }^{290}$ This would ensure that only those countries that deserved an expressive benefit from treaty membership would obtain it. Or membership in a treaty regime could be tiered, with a probationary period during the early years of membership followed by a comprehensive assessment of country practices for promotion to full membership. Or treaties could include provisions for removing countries that are habitually found in violation of the terms of the treaty from membership in the treaty regime.

Reforms aimed at enhancing the effectiveness of treaties through stronger monitoring provisions or tighter membership policies must of course be made with great caution. To the extent that such changes would increase the costs associated with joining treaties, it is possible that states will respond by simply opting out of the international human rights treaty system altogether. It is clear that human rights treaties need not be entirely toothless in order for countries to join them: Although they all have relatively stringent enforcement provisions, well over 100 countries have ratified the Optional Protocol to the Covenant on Civil and Political Rights, nearly fifty have ratified Articles 21 and 22 to the Torture Convention, and all the members of the Council of Europe have ratified the European Convention on Human Rights. Indeed, it is possible that the greater expressive value of membership in a treaty with strict monitoring would offset some of the additional costs associated with membership.

289. The policy has been adopted by the United Nations and advocated most prominently by Philip Alston, acting as an independent expert appointed by the Secretary General. See Alston, supra note 101, 9I 14-36 ("Universal ratification of the six core United Nations human rights treaties would establish the best possible foundation for international endeavors to promote respect for human rights.").

290. This would not be entirely unlike the procedure used by the World Trade Organization (WTO), which requires members to apply for membership and grants accession "on terms to be agreed" between the acceding government and the WTO. See Final Act Embodying the Results of the Uruguay Round of Multilateral Trade Negotiations. Apr. 15, 1994, art. XII, LEGAL INSTRUMENTS—RESULTS OF THE URUGUAY ROUND vol. 1, 33 I.L.M. 1125, 1150 (1994). 
Nonetheless, significant changes may provoke reactions that could harm, rather than enhance, the human rights treaty system, and hence reformers should proceed carefully.

Regardless of whether or not stronger monitoring and tighter membership policies are put in place, reforms aimed at enhancing countries' capability to comply with human rights treaties ought to be considered as well. The UN and regional organizations could play an important role in furthering treaty compliance and effectiveness if they not only better monitored treaties, but also provided countries with assistance in improving their human rights practices in order to meet treaty requirements. This assistance could include guidance in drafting effective legislation to protect rights and in crafting strategies for overcoming the institutional inertia that lies at the heart of intransigence in countries' human rights practices. ${ }^{291}$ It could also include assistance to build internal capacity-to build the institutions required-to carry out the treaties' directives. ${ }^{292}$ The United Nations and regional organizations are in a position to ease the transition costs for governments seeking to overcome inertia and implement true change. In making such assistance available while at the same time increasing monitoring, they can better ensure that countries will ratify treaties with the true intention of improving their practices.

In recent decades, faith in the power of international law to shape nations' actions has led to a focus on the creation of international law as a means to achieve human rights objectives. The treaties that have resulted may have played a role in changing discourse and expectations about rights, thereby improving the practices of all nations. Yet, based on the present analysis, ratification of the treaties by individual countries appears more likely to offset pressure for change in human rights practices than to augment it. The solution to this dilemma is not the abandonment of human rights treaties, but a renewed effort to enhance the monitoring and enforcement of treaty obligations to reduce opportunities for countries to use ratification as a symbolic substitute for real improvements in their citizens' lives.

291. Indeed, in many respects, the problem of international human rights treaty compliance can be seen as a specific instance of the broader challenge of translating law into social change. This insight is the foundation of decades of work by Ann and Robert Seidman, who have demonstrated that the mere passage of laws guaranteeing rights, without more, is not enough to make those rights reality. See, e.g., SEIDMAN ET AL., supra note 254.

292. This is a function that Chayes and Chayes refer to as "capacity-building." CHAYEs \& CHAYES, supra note 1, at 25. 


\section{APPENDIX A: LIST OF TREATIES}

\begin{tabular}{|c|c|c|}
\hline $\begin{array}{l}\text { Short Name of } \\
\text { Treaty }\end{array}$ & $\begin{array}{l}\text { Regional } \\
\text { Org. }\end{array}$ & Full Name and Citation of Treaty \\
\hline $\begin{array}{l}\text { Conv. on the } \\
\text { Political Rights } \\
\text { of Women }\end{array}$ & & $\begin{array}{l}\text { Convention on the Political Rights of Women, opened for } \\
\text { signature Mar. } 31,1953,27 \text { U.S.T. 1909, } 193 \text { U.N.T.S. } 135 \\
\text { (entered into force July 7, 1954). }\end{array}$ \\
\hline $\begin{array}{l}\text { Torture } \\
\text { Convention }\end{array}$ & & $\begin{array}{l}\text { Convention Against Torture and Other Cruel, Inhuman or } \\
\text { Degrading Treatment or Punishment, opened for signature } \\
\text { Dec. 10, } 1984 \text {, S. TREATY DOC. NO. 100-20 (1988), } 1465 \\
\text { U.N.T.S. } 85 \text { (entered into force June 26, 1987). }\end{array}$ \\
\hline Article 21 & & $\begin{array}{l}\text { Convention Against Torture and Other Cruel, Inhuman or } \\
\text { Degrading Treatment or Punishment, opened for signature } \\
\text { Dec. 10, 1984, art. 21, S. TREATY DOC. No. 100-20, at 26- } \\
27 \text { (1988), 1465 U.N.T.S. 85, 118-20 (entered into force } \\
\text { June 26, 1987). }\end{array}$ \\
\hline Article 22 & & $\begin{array}{l}\text { Convention Against Torture and Other Cruel, Inhuman or } \\
\text { Degrading Treatment or Punishment, opened for signature } \\
\text { Dec. 10, 1984, art. 22, S. TREATY DoC. No. 100-20, at 27- } \\
28(1988), 1465 \text { U.N.T.S. } 85,120 \text { (entered into force June } \\
\text { 26, 1987). }\end{array}$ \\
\hline $\begin{array}{l}\text { Covenant on } \\
\text { Civil and } \\
\text { Political Rights }\end{array}$ & & $\begin{array}{l}\text { International Covenant on Civil and Political Rights, } \\
\text { adopted Dec. 19, 1966, S. ExEC. Doc. E, 95-2, at 23 (1978), } \\
999 \text { U.N.T.S. 171 (entered into force Mar. 23, 1976). }\end{array}$ \\
\hline $\begin{array}{l}\text { Optional } \\
\text { Protocol }\end{array}$ & & $\begin{array}{l}\text { Optional Protocol to the International Covenant on Civil and } \\
\text { Political Rights, adopted Dec. 19, 1966, } 999 \text { U.N.T.S. } 302 .\end{array}$ \\
\hline $\begin{array}{l}\text { Genocide } \\
\text { Convention }\end{array}$ & & $\begin{array}{l}\text { Convention on the Prevention and Punishment of the Crime } \\
\text { of Gcnocide, adopted Dec. 9, 1948, S. ExEC. Doc. O, 81-1 } \\
\text { (1949), } 78 \text { U.N.T.S } 277 \text { (entered into force Jan. 12, 1951). }\end{array}$ \\
\hline $\begin{array}{l}\text { American } \\
\text { Convention on } \\
\text { Human Rights }\end{array}$ & OAS & $\begin{array}{l}\text { American Convention on Human Rights, opened for } \\
\text { signature Nov. 22, 1969, } 1144 \text { U.N.T.S. } 123 \text { (entered into } \\
\text { force July } 18,1978 \text { ). }\end{array}$ \\
\hline $\begin{array}{l}\text { American } \\
\text { Torture } \\
\text { Convention }\end{array}$ & OAS & $\begin{array}{l}\text { Inter-American Convention To Prevent and Punish Torture, } \\
\text { adopted Dec. 9, 1985, } 25 \text { I.L.M. } 519 \text { (entered into force } \\
\text { Feb. 28, 1987). }\end{array}$ \\
\hline $\begin{array}{l}\text { European } \\
\text { Convention on } \\
\text { Human Rights }\end{array}$ & $\mathrm{COE}$ & $\begin{array}{l}\text { Convention for the Protection of Human Rights and } \\
\text { Fundamental Freedoms, opened for signature Nov. 4, 1950, } \\
213 \text { U.N.T.S. } 221 \text { (entered into force Sept. 3, 1953). }\end{array}$ \\
\hline $\begin{array}{l}\text { European } \\
\text { Torture } \\
\text { Convention }\end{array}$ & $\mathrm{COE}$ & $\begin{array}{l}\text { European Convention for the Prevention of Torture and } \\
\text { Inhuman or Degrading Treatment or Punishment, opened } \\
\text { for signature Nov. 26, 1987, Europ. T.S. No. 126, } 27 \text { I.L.M. } \\
1152 \text { (entered into force Jan. 2, 1989). }\end{array}$ \\
\hline $\begin{array}{l}\text { African } \\
\text { Charter on } \\
\text { Human Rights }\end{array}$ & OAU & $\begin{array}{l}\text { African Charter on Human and Peoples' Rights, adopted } \\
\text { June 27, 1981, } 21 \text { I.L.M. } 58 \text { (entered into force Oct. 21, } \\
\text { 1986). }\end{array}$ \\
\hline
\end{tabular}

${ }^{a}$ Regional treaties are designated by the respective organization: the Organization of American States (OAS), the Council of Europe (COE), or the Organization of African Unity (OAU). Treaties not identified with a region are universal. 


\section{APPENDiX B: DATA SOURCES, DeFinitions, AND EXPLANATIONS FOR THE INDEPENDENT VARIABLES}

Over the last two decades, a growing body of studies has used quantitative methods to explain human rights practices of countries. ${ }^{293}$ The instant study draws upon and builds on these earlier studies by using them and the broader theoretical literature on human rights as the source for an inventory of hypotheses concerning human rights practices. ${ }^{294}$ This inventory, in turn, forms the foundation for the control variables used in this work. ${ }^{295}$ Below, I detail the definitions of and data sources for each of the control variables. I also discuss the rationale behind the inclusion of several nonsubstantive control variables.

\section{A. Treaty Variables}

To determine the correlation between treaty ratification and the human rights measures, I include a treaty variable as an independent variable in each of the analyses. I generated the treaty variables using data on treaties filed with the Secretary General of the United Nations from the United Nations Treaty Collection, ${ }^{296}$ and on regional treaties from the regional treaty organizations. ${ }^{297}$ The results for each treaty variable appear in bold in Tables 8-10 where they are statistically significant. The variable, measured as the sum of the number of years the treaty has been in effect (repeated for each country each year), gives greater weight to the ratification the longer it has been in effect. This makes it possible to take account of changes in behavior that take several years to accumulate. ${ }^{298}$ This approach-the

293. See sources cited supra note 185.

294. This strategy of compiling hypotheses is outlined in HUBERT M. BLALOCK, JR., THEORY CONSTRUCTION: From VERBAL to MATHEMATICAL Formulations (1969), and it is employed in Poe et al., supra note 185, at 292.

295. I discuss in greater detail the rationale behind the expectation that these variables will influence countries' human rights policies and the implications of empirical findings regarding their influence on countries' human rights practices in Oona A. Hathaway, Political and Economic Influences on Human Rights Practices: An Empirical Analysis (Jan. 2002) (unpublished manuscript, on file with author).

296. United Nations Treaty Collection, at http://untreaty.un.org/English/treaty.asp (last visited Apr. 2, 2002).

297. Org. of Afr. Unity, Status of Ratification, at http://www, up.ac.za/chr/ahrdb/ ahrdb_statorat.html (last visited Apr. 2, 2002); Org. of Am. States, Inter-American Treaties Approved Within the Framework of the OAS, at http://www.oas.org/juridico/english/treaties.html (last visited Apr. 2, 2002); Council of Eur., at http://www.coe.int (last visited Apr. 2, 2002); Office of the High Comm'r for Human Rights, Convention Against Torture, Statistical Survey of Individual Complaints Dealt with by the Committee Against Torture (Feb. 20, 2002), at http://www.unhchr.ch/html/menu2/8/stat3.htm.

298. Constructing the variables this way has the effect of magnifying changes in country ratings over time, whether positive or negative--which, as I argue in Part II, is appropriate given 
inclusion of a series of control variables along with the treaty variable as independent variables - ensures that any result found for the treaty variable will be independent of the other included factors.

\section{B. International War}

The data for international war for this study are based upon data compiled by the Center for Systemic Peace (CSP) ${ }^{299}$ Under international conflict, I include the events coded as "international event-interstate," which include conflicts between two polities as well as polities "resisting foreign domination (colonialism)." ${ }^{300}$ The coding ranges from 0 (no war) to 10 ("extermination and annihilation"). ${ }^{301}$ Where there was more than one episode of war in a country during the same time period, I added the magnitudes for each to form a single rating number. ${ }^{302}$

\section{Civil or Ethnic War}

The data for civil or ethnic war, like the data for international war, are based upon data compiled by the CSP. Under internal conflict, I include both ethnic conflict-defined as "[c]ivil-intrastate [conflict] involving rival

the expectation that treaties will have gradual and cumulative effects on country practices. When I instead operationalize the treaty variables as $0-1$ indicators, I find, as expected, many fewer statistically significant results, though all the results that remain significant are significant in the same direction. The coefficients for the Genocide Convention and Torture Convention reported in Table 8 are insignificant when the treaty variable is operationalized as a $0-1$ indicator. Similarly, the coefficients for all the regional treaties except the African Charter on Human Rights (without country dummies, with Torture as the dependent variable) are insignificant when 1 use a $0-1$ treaty indicator. (The African Charter shows a coefficient of 0.330 , with a standard error of 0.125 , which is significant at the $99 \%$ level.) For full democracies, the coefficients for Article 21 and the Convention on the Political Rights of Women are insignificant when I use a $0-1$ treaty indicator. The coefficients for the Genocide Convention for full democracies $(-1.096$, with a standard error of 0.381 ) and for the Torture Convention for full democracies $(0.650$, with a standard error of 0.235) are significant at the $99 \%$ level in the same direction as with a summed treaty variable. I was unable to obtain convergence for ratification of the remaining treaties by full democracies. In only one instance do I find a statistically significant result with a $0-1$ indicator that I do not find with a summed treaty variable. When I analyze the Covenant on Civil and Political Rights (for the group of countries as a whole) with the treaty variable as a $0-1$ indicator, I find positive statistically significant results. (The coefficient is 0.331 , the standard error is 0.096 , and the level of statistical significance is $99 \%$.) Thus operationalizing the treaty variable as a $0-1$ indicator also suggests (albeit more weakly) that with the exception of fully democratic nations, ratification of human rights treaties by countries is often associated with worse ratings than would otherwise be expected.

299. See Monty G. Marshall, Major Episodes of Political Violence, 1946-1999 (Oct. 1, 2000), at http://members.aol.com/CSPmgm/warlist.htm.

300. Id.

301. Id.

302. For more on the coding scheme of the CSP database, see Center for Systemic Peace, Assessing the Societal and Systemic Impact of Warfare: Coding Guidelines, at http://members.aol.com/CSPingm/warcode.htm (last visited Apr. 2, 2002). 
political groups" ${ }^{303}$-and civil conflict-defined as "[e]thnic-intrastate [conflict] involving the state agent and a distinct ethnic group." ${ }^{304}$ The coding methodology used for this variable is identical to that used for the international war variable. ${ }^{305}$

\section{Population Size}

The source of these data is the World Development Indicators CDROM. ${ }^{306}$ It defines "Population, total" as follows: "Total Population is based on the de facto definition of population, which counts all residents regardless of legal status or citizenship. Refugees not permanently settled in the country of asylum are generally considered to be part of the population of their country of origin." 307

\section{E. Population Growth}

This variable is calculated from the total population data in the World Development Indicators CD-ROM. ${ }^{308}$ It is equal to the percent change in population from the previous year.

\section{F. New Regime}

This variable is dichotomous, with an indicator of 1 where a regime has been in place for five years or fewer and 0 in all other cases. The data on regime duration are drawn from the "durable" indicator in the Polity IV data set, a database that is widely used and well respected among social scientists. ${ }^{309}$

\section{G. Democracy}

There has been a rich debate on how best to define and measure democracy. ${ }^{310}$ I use the best available comprehensive data on democracy,

303. Marshall, supra note 299.

304. Id.

305. See supra text accompanying note 302 .

306. WORLD DEVELOPMENT INDICATORS (World Bank CD-ROM, 2000).

307. Id.

308. Id.

309. See Monty G. Marshall \& Keith Jaggers, Polity IV Project: Political Regime Characteristics and Transitions, 1800-2000, at http://www.bsos.umd.edu/cidcm/inscr/polity/ index.htm (last visited Mar. 12, 2002) (including a description of variables and a link to the data set).

310. See, e.g., JOHN D. MAY, OF THF, CONDITIONS AND MEASURES OF DEMOCRACY (1973) (cataloguing and critiquing several prior efforts at measuring democracy); ON MEASURING DEMOCRACY (Alex Inkeles ed., 1991) (providing a comprehensive analysis of the challenges 
which are found in the Polity IV data set. ${ }^{311}$ The Polity project defines democracy, which ranges from 0 (low) to 10 (high), as "general openness of political institutions." ${ }^{312}$ The scale is constructed additively using coded data on six separate variables: competitiveness of executive recruitment, openness of executive recruitment, regulation of executive recruitment, constraints on the chief executive, regulation of political participation, and competitiveness of political participation. ${ }^{313}$

\section{H. Gross National Product per Capita}

The source of these data is the World Development Indicators CDROM. ${ }^{314}$ It defines "GNP per capita (constant 1995 US\$)" as follows:

GNP per capita is gross national product divided by midyear population. GNP is the sum of gross value added by all resident producers plus any taxes (less subsidies) that are not included in the valuation of output plus net receipts of primary income (employee compensation and property income) from nonresident sources. Data are in constant 1995 U.S. dollars. ${ }^{315}$

\section{Global Economic Interdependence}

This indicator measures the percentage of gross domestic product made up by trade. The source of these data is the World Development Indicators CD-ROM. ${ }^{316}$ It defines "Trade (\% of GDP)" as follows: "Trade is the sum of exports and imports of goods and services measured as a share of gross domestic product." 317

\section{J. Dependence on Foreign Aid}

This variable measures the percentage of the country's GDP made up by official development assistance, which includes disbursements of loans

inherent in measuring democracy); Kenneth A. Bollen, Issues in the Comparative Measurement of Political Democracy, 45 AM. SOC. REv. 370, $371-77$ (1980) (discussing the controversial aspects and limitations of the then-commonly-used indices of democracy and proposing a revised index of democracy); Kenneth Bollen, Liberal Democracy: Validity and Method Factors in Cross-National Measures, 37 AM. J. POL. SCI. 1207, 1208-10 (1993) (examining the definition and measurement of liberal democracy).

311. Marshall \& Jaggers, supra note 309.

312. Polity IV Dataset Variables List, at www.bsos.umd.edu/cidcm/inscr/polity/index.htm (last visited Mar. 12, 2002).

313. Id.

314. WORLD DEVELOPMENT INDICATORS, supra note 306.

315. Id.

316. Id.

317. Id. 
and credits from the World Bank and International Monetary Fund, as well as official country-to-country assistance. The source of the data is the World Development Indicators CD-ROM. ${ }^{318}$ It defines "Aid (\% of GDP)" as follows:

Official development assistance and net official aid record the actual international transfer by the donor of financial resources or of goods or services valued at the cost to the donor, less any repayments of loan principal during the same period. Aid dependency ratios are computed using values in U.S. dollars converted at official exchange rates. ${ }^{319}$

In the data set, $\mathrm{I}$ inserted 0 wherever the World Bank provided no data, on the assumption that the data would likely have been reported if official development aid had been provided, that countries for which there was no entry solely because GDP data were unavailable would be thrown out of the data set in the regression analysis, and that therefore this alteration would not skew the results. (It is apparent that the World Bank CD-ROM leaves the entry blank where no aid was provided, because most of the major industrialized countries have blank entries.)

\section{K. Economic Growth}

The source of these data is the World Development Indicators CDROM. ${ }^{320}$ It defines "GDP growth (annual \%)" as follows:

Annual percentage growth rate of GDP at market prices based on constant local currency. Aggregates are based on constant 1995 U.S. dollars. GDP measures the total output of goods and services for final use occurring within the domestic territory of a given country, regardless of the allocation to domestic and foreign claims. Gross domestic product at purchaser prices is the sum of gross value added by all resident producers in the economy plus any taxes and minus any subsidies not included in the value of the products. It is calculated without making deductions for depreciation of fabricated assets or for depletion and degradation of natural resources. The residency of an institution is determined on the basis of economic interest in the territory for more than a year. ${ }^{321}$ 


\section{State Failure}

This variable is dichotomous, with an indicator of 1 for any year in which there is a "complete collapse of central regime authority," ${ }^{322}$ and a 0 for any year in which there is not. The variable is drawn directly from the "state failure" indicator in the Polity IV data set. ${ }^{323}$

\section{Country Dummies}

I include in the analyses dummy variables for each country to control for otherwise unaccounted-for sources of variation in the data (omitted variable bias). (I do not include the coefficients in Tables 8-10.) I use the dummy variables because human rights practices may vary from country to country for cultural, historical, or other reasons not otherwise accounted for. The use of country dummies helps address this dimension of omitted variable bias. I run each analysis with and without country dummies, reporting the results without country dummies only if they vary importantly.

\section{N. Time Trend}

I seek to address a second dimension of omitted variable bias by including a time trend variable as an independent variable. Human rights practices may exhibit trends over time because of improving worldwide standards independent of the treaties, the proliferation of media and communications methods that make it more difficult to obscure human rights violations, the proliferation of nongovernmental organizations dedicated to monitoring countries' human rights practices, and other reasons independent of treaty ratification itself and not otherwise accounted for. A time trend variable is commonly used in time-series estimations to control for this type of variation and is known as the "secular trend" or the "long-term trend." It describes the long-term movements of the dependent variable, $y_{t}$. It does not imply that the series always moves in the same direction, but it does indicate an overall directional trend over the entire time period. ${ }^{324}$ In economic applications, for example, the time trend is frequently used as a proxy for technical progress. In general, the time trend variable will pick up any time-related factors affecting the dependent variable. ${ }^{325}$

322. Polity IV Dataset Variables List, supra note 312 (internal quotation marks omitted).

323. Marshall \& Jaggers, supra note 309.

324. PAUl NEWBOLD, STATISTICS FOR BUSINESS AND ECONOMICS 692 (4th ed. 1995).

325. CHRISTOPHER DOUGHERTY, INTRODUCTION TO ECONOMETRICS 183-84 (1992). An altemative approach would have been to include dummy variables for each year. 1 chose not to do 


\section{O. Lagged Dependent Variable}

The lagged dependent variable-which is determined by the prior year's human rights rating-is aimed at addressing autocorrelation. When variables display some linear trends (as is of course true here), successive values tend to be fairly close together. One way of modeling such behavior is by means of an autoregression. ${ }^{326}$ Here, the inclusion of a lagged dependent variable is effectively a first-order autoregressive scheme. The use of a lagged dependent variable to address autocorrelation in such circumstances is well-accepted practice. ${ }^{327}$ Notably, the use of a lagged dependent variable generally does not have a substantial impact on the results for the treaty variable. ${ }^{328}$

so not only because this would have taken up 39 additional degrees of freedom, but also because the results would not have detected consistent change in the dependent variable over time. Moreover, worldwide events that are likely to affect human rights practices (such as widespread war, worldwide economic downturn, or the like) are addressed in substantial part by the inclusion of control variables that measure these events more directly.

326. JACK JOHNSTON \& JOHN DINARDO, ECONOMETRIC METHODS 52-53 (4th ed. 1997).

327. See Christian Davenport, Multi-Dimensional Threat Perception and State Repression: An Inquiry into Why States Apply Negative Sanctions, 39 AM. J. POL. SCI. 683, 698-99 (1995); Poe et al., supra note 185 , at 306 .

328. The results for the treaty variables are statistically significant in the same direction both with and without the lagged dependent variable with only a few exceptions. The coefficient for the Convention on the Political Rights of Women (for the group of countries as a whole) is negative and significant at the $99 \%$ level when I omit the lagged dependent variable. The coefficient is -0.001 , with a standard error of 0.0004 . The coefficient is insignificant, however, when standard errors are adjusted for clustering on country. The coefficient for the American Convention on Human Rights with the Fair Trial dependent variable is negative, but not significant, when I omit a lagged dependent variable (the coefficient is -0.266 and the standard error is 0.127 ). In the analyses of full democracies' practices, I find a newly significant coefficient for the Covenant on Civil and Political Rights with Civil Liberty as the dependent variable (the coefficient is -0.035 , the standard error is 0.013 , and the significance level is $99 \%$ ) when I omit lagged dependent variables. 
APPENDIX C: CODED DATA AND COMPLETE STATISTICAL RESUlTS

TABLE 6. CODED DATA ON TORTURE

\begin{tabular}{|c|c|c|c|c|c|c|c|c|c|c|c|c|c|c|c|}
\hline Country & 85 & 86 & 87 & 88 & 89 & 90 & 91 & 92 & 93 & 94 & 95 & 96 & 97 & 98 & 99 \\
\hline Afghanisłan & 5 & 5 & 5 & 5 & 5 & 5 & 4 & & 4 & 5 & 5 & 4 & 5 & 5 & 5 \\
\hline Albania & 3 & 3 & 3 & 2 & 2 & 3 & 2 & 1 & 2 & 2 & 2 & 2 & 2 & 3 & 3 \\
\hline Algeria & 1 & 3 & 3 & 4 & 2 & 3 & 3 & 3 & 5 & 5 & 5 & 5 & 5 & 5 & 5 \\
\hline Angola & 3 & 3 & 3 & 3 & 3 & 3 & 3 & 4 & 2 & 2 & 2 & 2 & 4 & 4 & 5 \\
\hline Argentina & 2 & 2 & 2 & 3 & 3 & 3 & 3 & 4 & 2 & 2 & 2 & 2 & 3 & 4 & 4 \\
\hline Armenia & & & & & & & & 2 & 2 & 1 & 2 & 2 & 4 & 4 & 4 \\
\hline Australia & 1 & 1 & 1 & $l$ & 1 & 3 & 3 & 3 & 2 & 3 & 1 & 2 & 3 & 2 & 2 \\
\hline Austria & 1 & 1 & 2 & 1 & 1 & 2 & 2 & 2 & 2 & 2 & 2 & 2 & 2 & 2 & 2 \\
\hline Azerbaijan & & & & & & & & 3 & 2 & 2 & 4 & 4 & 4 & 4 & 4 \\
\hline Bahrain & 2 & 3 & 3 & 3 & 3 & 3 & & & 3 & 3 & 5 & 4 & 3 & 4 & 4 \\
\hline Bangladesh & 3 & 3 & 3 & 3 & 3 & 3 & 4 & 4 & 4 & 3 & 5 & 5 & 5 & 5 & 5 \\
\hline Bclarus & & & & & & & & 2 & 2 & 3 & 4 & 3 & 3 & 2 & 2 \\
\hline BelgiuIn & 1 & 2 & 1 & 1 & I & 1 & 1 & 1 & 2 & 1 & 1 & 1 & 1 & 1 & 1 \\
\hline Benin & 3 & 3 & 3 & 3 & 3 & 1 & 1 & 1 & 1 & 1 & 1 & 1 & 1 & 1 & 1 \\
\hline Bhutan & 1 & 1 & 1 & 1 & 1 & 1 & 3 & 5 & 3 & 3 & & 3 & I & 3 & 2 \\
\hline Bolivia & 2 & 2 & 3 & 2 & 3 & 3 & 3 & 3 & 3 & 2 & 2 & 2 & 2 & 3 & 3 \\
\hline Bosnia and Herzegovina & & & & & & & & 4 & 4 & 4 & 5 & 3 & 3 & 3 & 4 \\
\hline Botswana & 1 & 1 & 2 & 3 & 3 & 2 & 1 & 2 & 4 & 3 & 2 & 2 & 2 & 2 & 2 \\
\hline Brazil & 5 & 5 & 5 & 5 & 5 & 5 & 5 & 5 & 4 & 4 & 4 & 4 & 4 & 4 & 5 \\
\hline Bulgaria & 3 & 2 & 3 & 4 & 4 & 1 & 1 & 2 & 2 & 2 & 2 & 3 & 3 & 2 & 3 \\
\hline Burkina Faso & 3 & 2 & 3 & 3 & 3 & 3 & 3 & 3 & 3 & 3 & 3 & 3 & 2 & 2 & 2 \\
\hline Burundi & 2 & 2 & 2 & 3 & 3 & 2 & 2 & 4 & 3 & 3 & 3 & 2 & 3 & 3 & 3 \\
\hline Carnboutia (Kampuchea) & 5 & 4 & 4 & 4 & 3 & 3 & 2 & 3 & 3 & 3 & 3 & 3 & 4 & 3 & 5 \\
\hline Cameroon & 2 & 3 & 1 & 2 & 3 & 2 & 4 & 4 & 5 & 4 & 5 & 4 & 3 & 3 & 3 \\
\hline Canada & 1 & 1 & 1 & 1 & $\hat{1}$ & 1 & 1 & 2 & 1 & 2 & 2 & 1 & 1 & 1 & l \\
\hline Central African Republic & 3 & 2 & 2 & 1 & 2 & 3 & 2 & 4 & 2 & 2 & 2 & 3 & 5 & 4 & 3 \\
\hline Chad & 5 & 4 & 2 & 3 & 3 & 4 & 4 & 3 & 3 & 3 & 4 & 2 & 4 & 3 & 3 \\
\hline Chile & 4 & 3 & 3 & 3 & 3 & 3 & 3 & 3 & 3 & 3 & 3 & 3 & 3 & 3 & 2 \\
\hline China & $\mathbf{I}$ & 3 & 3 & 3 & 3 & 4 & 4 & 5 & 5 & 5 & 5 & 5 & 3 & 3 & 3 \\
\hline Colombia & 3 & 3 & 3 & 2 & 5 & 5 & 5 & 3 & 5 & 3 & 3 & 4 & 5 & 4 & 3 \\
\hline Comoros & 3 & 3 & 3 & 3 & 3 & 2 & 3 & 1 & 1 & 2 & 1 & 1 & 4 & 2 & 2 \\
\hline Congo, Republic of & 3 & 3 & 3 & 4 & 3 & 4 & 4 & 2 & 3 & 3 & 3 & 5 & 4 & 3 & 2 \\
\hline Congo, Democratic Republic of & 5 & 5 & 4 & 4 & 3 & 2 & 3 & 4 & 5 & 5 & 4 & 4 & 4 & 4 & 4 \\
\hline Costa Rica & 1 & 1 & 1 & 1 & 2 & 2 & 1 & 2 & 2 & 2 & 2 & 2 & 2 & 2 & 2 \\
\hline Côte D'Ivoire & 2 & 2 & 2 & 2 & 2 & 3 & 2 & 2 & 2 & 2 & 2 & 3 & 4 & 4 & 4 \\
\hline Croatia & & & & & & & & 2 & 3 & 4 & 3 & 1 & 2 & 2 & 2 \\
\hline Cuba & 4 & 4 & 4 & 4 & 3 & 3 & 3 & 4 & 4 & 3 & 3 & 3 & 3 & 2 & 2 \\
\hline Cyprus & i & 1 & 1 & 1 & 1 & 1 & 1 & 2 & 3 & 2 & 2 & 2 & 3 & 2 & 2 \\
\hline Crochoslovakia & 3 & 3 & 2 & 2 & 2 & $i$ & 1 & 1 & 1 & 1 & 2 & 2 & 2 & 2 & 4 \\
\hline Denmark & 1 & 1 & 1 & 1 & 1 & 1 & 2 & 1 & 1 & 2 & 1 & 1 & 1 & 1 & $i$ \\
\hline Djibouti & 3 & 2 & 1 & 2 & 3 & 3 & 4 & 3 & 3 & 2 & 2 & 3 & 3 & 4 & 4 \\
\hline Dominican Republic & 2 & 2 & 2 & 2 & 2 & 2 & 3 & 4 & 2 & 2 & 2 & 4 & 3 & 3 & 3 \\
\hline Ecuador & 3 & 2 & 3 & 4 & 3 & 5 & 4 & 2 & 3 & 3 & 3 & 3 & 2 & 3 & 3 \\
\hline Egypt & 3 & 3 & 3 & 4 & 4 & 4 & 4 & 4 & 4 & 4 & 5 & 4 & 4 & 4 & 4 \\
\hline El Salvador & 4 & 3 & 3 & 3 & 4 & 4 & 4 & 3 & 3 & 3 & 3 & 2 & 2 & 2 & 2 \\
\hline Equatorial Guinea & 3 & 3 & 4 & 3 & 3 & 5 & 5 & 5 & 5 & 5 & 4 & 4 & 3 & 4 & 3 \\
\hline Eritrea & & & & & & & & & 1 & 2 & 2 & 1 & 2 & 2 & 2 \\
\hline Estonia & 4 & 4 & 4 & 4 & 4 & 3 & & & 2 & 2 & 2 & 2 & 2 & 2 & 2 \\
\hline Ethiopia & 4 & 4 & 4 & 3 & 4 & 4 & 5 & 2 & 2 & 3 & 2 & 2 & 3 & 3 & 2 \\
\hline Fiji & 1 & 1 & 3 & 2 & 2 & 2 & 2 & 2 & 2 & 2 & 2 & 2 & 2 & 2 & 2 \\
\hline Finland & 1 & 1 & 1 & 1 & $i$ & 1 & 1 & 1 & 1 & 1 & 1 & 1 & 1 & 1 & 1 \\
\hline France & I & 1 & 1 & 2 & 2 & 2 & 1 & 1 & 2 & 1 & 2 & 2 & 2 & 2 & 2 \\
\hline Gabon & 2 & 2 & 1 & 3 & 3 & 2 & 3 & 3 & 4 & 4 & 3 & 3 & 3 & 3 & 2 \\
\hline Gambia & 2 & 2 & 2 & 2 & 2 & 2 & 2 & 2 & 2 & 2 & 3 & 3 & 3 & 2 & 2 \\
\hline Georgia & & & & & & & & 4 & 5 & 4 & 3 & 4 & 4 & 5 & 4 \\
\hline Germany, United & & & & & & 1 & 1 & 1 & 2 & 2 & 2 & 2 & 2 & 2 & 2 \\
\hline Germany. East & & & & & & & & & & & & & & & \\
\hline Germany, West & $\mathbf{I}$ & 1 & 2 & 1 & 1 & & & & & & & & & & \\
\hline Ghane & 3 & 3 & 3 & 3 & 2 & 1 & 2 & 2 & 3 & 2 & 2 & 2 & 2 & 3 & 2 \\
\hline Greece & 2 & 1 & 3 & 2 & 3 & 2 & 2 & 1 & 3 & 2 & 3 & 2 & 2 & 2 & 2 \\
\hline Guatemala & 4 & 3 & 3 & 3 & 2 & 4 & 4 & 3 & 3 & 4 & 4 & 3 & 3 & 3 & 3 \\
\hline Guinea & 2 & 2 & 2 & 3 & 2 & 3 & 3 & 2 & 3 & 3 & 3 & 3 & 4 & 4 & 4 \\
\hline Guinea-Bissau & 4 & 3 & 2 & 3 & 3 & 2 & 2 & 3 & 4 & 3 & 3 & 2 & 2 & 4 & 3 \\
\hline Guyana & 3 & 3 & 2 & 2 & 2 & 2 & 2 & 3 & 3 & 2 & 2 & 2 & 2 & 2 & 2 \\
\hline Haiti & 3 & 2 & 3 & 3 & 3 & 4 & 3 & 4 & 4 & 5 & 2 & 4 & 4 & 4 & 4 \\
\hline Honduras & 2 & 2 & 3 & 3 & 3 & 4 & 3 & 3 & 4 & 3 & 3 & 3 & 4 & 3 & 3 \\
\hline Hungary & 1 & 2 & 1 & 1 & 1 & 1 & 1 & 2 & 2 & 2 & 2 & 2 & 2 & 2 & 2 \\
\hline Iceland & 1 & 1 & 1 & 1 & 1 & $i$ & I & 1 & 1 & 1 & 1 & 1 & 2 & 1 & 1 \\
\hline India & 3 & 4 & 4 & 4 & 4 & 4 & 4 & 4 & 4 & 4 & 5 & 5 & 4 & 4 & 4 \\
\hline
\end{tabular}

HeinOnline -- 111 Yale L.J. 2034 2001-2002

Imaged with the Permission of Yale Law Journal 


\begin{tabular}{|c|c|c|c|c|c|c|c|c|c|c|c|c|c|c|c|}
\hline Indonesial & 3 & 3 & 4 & 4 & 4 & 4 & 4 & 4 & 5 & 4 & 3 & 5 & 4 & 4 & 5 \\
\hline lran & 5 & 5 & 5 & 5 & 4 & 3 & 3 & 3 & 3 & 3 & 3 & 3 & 3 & 4 & 4 \\
\hline Iraq & 5 & 5 & 5 & 5 & 5 & 5 & 5 & 5 & 5 & 5 & 5 & 5 & 5 & 5 & 5 \\
\hline Ireland & 2 & 2 & 2 & 2 & 1 & 1 & 1 & 1 & 1 & 2 & 1 & 2 & 2 & 2 & 2 \\
\hline Israel & 1 & 1 & 4 & 4 & 4 & 1 & 1 & 1 & 2 & 2 & 3 & 2 & 4 & 4 & 3 \\
\hline Italy & 1 & 2 & 3 & 1 & 1 & 1 & 1 & 2 & 2 & 3 & 2 & 2 & 2 & 2 & 3 \\
\hline Jamaica & 2 & 3 & 3 & 3 & 3 & 4 & 4 & 4 & 4 & 3 & 2 & 2 & 2 & 2 & 3 \\
\hline Japan & 1 & 1 & 1 & 1 & 1 & 3 & 3 & 2 & 3 & 3 & 2 & 3 & 3 & 3 & 3 \\
\hline Jordan & 2 & 2 & 3 & 3 & 3 & 1 & 3 & 3 & 3 & 3 & 3 & 3 & 3 & 3 & 3 \\
\hline Kazakhstan & & & & & & & & 3 & 1 & 2 & 3 & 3 & 3 & 3 & 3 \\
\hline Kenya & 3 & 3 & 3 & 3 & 3 & 3 & 3 & 3 & 3 & 3 & 3 & 4 & 4 & 4 & 4 \\
\hline Korea. Republic of & 3 & 3 & 3 & 2 & 3 & 4 & 3 & 3 & 2 & 3 & 3 & 3 & 2 & 3 & 3 \\
\hline Korea, DPR & 4 & 4 & 4 & 4 & & & & & & & & & & & \\
\hline Kuwait & 2 & 3 & 3 & 3 & 3 & 4 & 4 & 3 & 3 & 3 & 2 & 2 & 2 & 2 & 2 \\
\hline Kyrgyzstan & & & & & & & & 1 & 1 & 2 & 1 & 2 & 2 & 2 & 2 \\
\hline Laos & 2 & 2 & 3 & 2 & 2 & 3 & 1 & 1 & 1 & 2 & 1 & 1 & 1 & 2 & 3 \\
\hline Latvia & 4 & 4 & 4 & 4 & 3 & 3 & & 1 & 2 & 2 & 2 & 2 & 2 & 2 & 2 \\
\hline Lebanon & 3 & 2 & 3 & 4 & 3 & 3 & 2 & 3 & 3 & 3 & 3 & 3 & 3 & 4 & 4 \\
\hline L.esotho & 2 & 2 & 2 & 3 & 2 & 2 & 2 & 2 & 2 & 3 & 2 & 1 & 2 & 2 & 2 \\
\hline Liberia & 3 & 3 & 3 & 3 & 3 & 5 & 3 & 4 & 4 & 4 & 3 & 3 & 3 & 4 & 3 \\
\hline Libya & 4 & 3 & 4 & 4 & & 3 & 3 & 3 & 3 & 3 & 3 & 3 & 3 & 3 & 3 \\
\hline Litheania & 4 & 4 & 4 & 4 & 4 & 3 & & 1 & 2 & 2 & 2 & 2 & 2 & 2 & 2 \\
\hline Luxembourg & 1 & 1 & 1 & 1 & 1 & 1 & 1 & I & 1 & 1 & 1 & 1 & 1 & 1 & 1 \\
\hline Macedonia & & & & & & & & 2 & 2 & 2 & 2 & 2 & 2 & 2 & 2 \\
\hline Madagascar & 3 & 3 & 3 & 3 & 3 & 2 & 2 & i & 3 & 3 & 3 & 3 & 3 & 3 & 3 \\
\hline Malawi & 2 & 2 & 3 & 2 & 2 & 3 & 3 & 3 & 2 & 2 & 2 & 3 & 3 & 2 & 2 \\
\hline Malaysia & 1 & 1 & 2 & 2 & 1 & 2 & 1 & 2 & 2 & 2 & 3 & 2 & 2 & 3 & 3 \\
\hline Mali & 3 & 3 & 3 & 2 & 3 & 3 & 1 & 1 & 1 & 1 & 2 & 1 & 3 & 3 & 1 \\
\hline Mauritania & 3 & 1 & 3 & 3 & 4 & 3 & 4 & 5 & 2 & 3 & 3 & 3 & 3 & 2 & 2 \\
\hline Mauritius & 1 & 1 & 1 & 1 & 1 & 2 & 2 & 2 & 2 & 2 & 2 & 3 & 2 & 2 & 2 \\
\hline Mexico & 3 & 3 & 3 & 3 & 3 & 3 & 5 & 5 & 4 & 3 & 3 & 5 & 5 & 5 & 5 \\
\hline Moldova & & & & & & & & 3 & 2 & 2 & 2 & 2 & 2 & 2 & 3 \\
\hline Mongolia & & & & & & 1 & 1 & i & 1 & 2 & 2 & 2 & 2 & 2 & 3 \\
\hline Morocco & 3 & 4 & 3 & 3 & 4 & 3 & 3 & 3 & 3 & 3 & 3 & 3 & 3 & 3 & 3 \\
\hline Mozambique & 4 & 3 & 3 & 4 & 4 & 3 & 3 & 3 & 3 & 4 & 4 & 4 & 4 & 4 & 3 \\
\hline Myanmar (Burma) & 3 & 3 & 3 & 3 & 4 & 5 & 4 & 3 & 2 & 3 & 4 & 3 & 3 & 4 & 4 \\
\hline Namibia & 3 & 3 & 2 & 3 & 3 & 3 & 3 & 3 & 3 & 2 & 2 & 2 & 2 & 2 & 3 \\
\hline Nepal & 3 & 4 & 5 & 4 & 4 & 4 & 4 & 4 & 3 & 3 & 3 & 4 & 4 & 4 & 4 \\
\hline Netherlands & 1 & 1 & 1 & 1 & 1 & 1 & 1 & 1 & 1 & 2 & 1 & 1 & 1 & 1 & 1 \\
\hline New Zealand & 1 & 1 & 1 & 1 & 1 & 1 & 1 & 1 & 1 & 1 & l & 1 & I & 1 & 1 \\
\hline Nicaragua & 4 & 3 & 4 & 4 & 4 & 3 & 3 & 3 & 3 & 3 & 4 & 3 & 3 & 3 & 3 \\
\hline Niger & 3 & 2 & 2 & 3 & 2 & 3 & 3 & 2 & 2 & 2 & 1 & 2 & 2 & I & 2 \\
\hline Nigeria & 3 & 1 & 2 & 3 & 3 & 4 & 4 & 5 & 5 & 5 & 5 & 5 & 5 & 4 & 3 \\
\hline Norway & 1 & 1 & 1 & 1 & 1 & 1 & 1 & 1 & 1 & 2 & 1 & 1 & 1 & I & 1 \\
\hline Oman & 1 & 1 & 1 & 2 & 2 & 1 & 2 & l & 2 & 2 & 2 & 2 & 2 & 2 & 2 \\
\hline Pakistan & 5 & 3 & 3 & 4 & 4 & 4 & 4 & 4 & 5 & 5 & 5 & 4 & 5 & 5 & 5 \\
\hline Panarna & 2 & 2 & 4 & 3 & 4 & 2 & 3 & 3 & 2 & 2 & 2 & 2 & 2 & 2 & 2 \\
\hline Papua-New Guinea & 1 & 1 & 1 & 1 & 3 & 3 & 4 & 3 & 3 & 3 & 2 & 3 & 2 & 3 & 3 \\
\hline Paraguay & 4 & 4 & 3 & 3 & 3 & 4 & 3 & 4 & 3 & 3 & 3 & 3 & 3 & 4 & 4 \\
\hline Peru & 4 & 4 & 5 & 4 & 5 & 5 & 4 & 5 & 5 & 5 & 4 & 5 & 5 & 5 & 5 \\
\hline Philippines & 4 & 4 & 4 & 4 & 4 & 4 & 4 & 4 & 4 & 3 & 3 & 3 & 3 & 3 & 3 \\
\hline Poland & 3 & 3 & 4 & 3 & 2 & 2 & 2 & 2 & 2 & 2 & & 2 & 2 & 2 & 2 \\
\hline Portugal & 1 & 2 & 2 & 1 & 1 & 3 & 2 & 2 & 3 & 2 & 2 & 2 & 1 & 2 & 3 \\
\hline Qatar & 2 & 2 & 1 & 3 & 2 & $\mathbf{l}$ & 2 & 1 & 1 & 1 & 1 & 1 & $\mathbf{I}$ & $\mathbf{I}$ & I \\
\hline Romania & 4 & 3 & 3 & 3 & 3 & 3 & 3 & 2 & 4 & 2 & 4 & 2 & 3 & 2 & 4 \\
\hline Russia (or former [USSR) & 4 & 4 & $\$$ & 4 & 4 & 4 & 3 & 4 & 3 & 3 & 5 & 4 & 4 & 5 & 5 \\
\hline Rwanda & 3 & 1 & 1 & 1 & 1 & 2 & 4 & 3 & 4 & 5 & 2 & 2 & 3 & 3 & 3 \\
\hline Saudi Arabia & 3 & 2 & 4 & 3 & 4 & 4 & 4 & 3 & 3 & 3 & 3 & 3 & 3 & 3 & 3 \\
\hline Senegal & 3 & 2 & 2 & 2 & 3 & 4 & 3 & 3 & 3 & 3 & 3 & 3 & 3 & 3 & 3 \\
\hline Sierra Leone & 3 & 3 & 3 & 3 & 3 & 2 & 2 & 2 & 3 & 3 & 2 & 4 & 4 & 5 & 2 \\
\hline Singapore & 2 & 1 & 3 & 2 & 3 & 2 & 1 & 2 & 2 & 3 & 2 & 2 & 2 & 2 & 2 \\
\hline Slovak Republic & & & & & & & & & 1 & 1 & 3 & 2 & 2 & 2 & 2 \\
\hline Slovenia & & & & & & & & 1 & 1 & 1 & 1 & 1 & 1 & 1 & 1 \\
\hline Somalia & 3 & 3 & 4 & 4 & 3 & 3 & 3 & 4 & 3 & 3 & & & & & \\
\hline South Africa & 3 & 4 & 4 & 4 & 4 & 3 & 3 & 3 & 4 & 4 & 3 & 3 & 3 & 3 & 3 \\
\hline Spain & 3 & 3 & 3 & 2 & 1 & 1 & 1 & 2 & 2 & 3 & 4 & 3 & 3 & 3 & 3 \\
\hline Sri Lanka & 3 & 3 & 3 & 4 & 4 & 3 & 4 & 4 & 4 & 5 & 3 & 3 & 3 & 3 & 3 \\
\hline Sudan & 1 & 3 & 3 & 3 & 3 & 5 & 5 & 5 & 5 & 5 & 5 & 5 & 4 & 5 & 3 \\
\hline Swaziland & 2 & 2 & 2 & 2 & 2 & 2 & 2 & 2 & 3 & 4 & 3 & 4 & 3 & 3 & 3 \\
\hline Sweden & 1 & 1 & 1 & 1 & 2 & 1 & 1 & 1 & 1 & 1 & 2 & 2 & 2 & 2 & 1 \\
\hline Swítzeriand & 1 & 1 & 1 & 1 & 1 & 1 & 1 & 1 & 1 & 2 & 1 & 1 & 3 & 4 & 2 \\
\hline Syria & 5 & 5 & 4 & 5 & 5 & 5 & 5 & 5 & 5 & 5 & 5 & 5 & 5 & 5 & 5 \\
\hline Tajikistan & & & & & & & & 3 & 3 & 4 & 4 & 4 & 3 & 4 & 4 \\
\hline Tanzania & 3 & 4 & 3 & 3 & 4 & 4 & 4 & 4 & 4 & 4 & 4 & 4 & 3 & 3 & 3 \\
\hline Thailand & 2 & 3 & 3 & 3 & 3 & 3 & 3 & 3 & 3 & 3 & 3 & 4 & 2 & 2 & 3 \\
\hline Togo & 4 & 5 & 4 & 3 & 4 & 3 & & 3 & 4 & 4 & 3 & 3 & 3 & 3 & 3 \\
\hline Tonga & & 1 & 1 & 1 & 1 & 1 & 1 & 1 & 1 & 1 & 1 & 1 & 1 & 1 & 1 \\
\hline Tunisia & 2 & 2 & 3 & 3 & 3 & 3 & 3 & 4 & 3 & 3 & 2 & 3 & 3 & 4 & 3 \\
\hline Turkey & 5 & 5 & 5 & 3 & 5 & 4 & 4 & 4 & 4 & 4 & 4 & 5 & 5 & 5 & 5 \\
\hline
\end{tabular}

HeinOnline -- 111 Yale L.J. 2035 2001-2002 Imaged with the Permission of Yale Law Journal 
Turkmenistan

Uganda

Ukraine

United Arab Emirates

United Kingdom

United States

Uruguay

Uzbekistan

Venezuela

Vietnam, North

Vietnam, South

Vietnam, United

Yemen, North

Yemen, South

Yemen, United

Yugoslavia

Zambia

Zimbabwe

$\begin{array}{lllllllllllllll}4 & 3 & 3 & 3 & 4 & 4 & 4 & 3 & 3 & 3 & 3 & 3 & 3 & 3 & \\ 1 & 1 & 1 & 3 & 3 & 3 & 1 & 1 & 1 & 1 & 1 & 2 & 2 & 2 & 2 \\ 3 & 2 & 1 & 2 & 1 & 1 & 2 & 3 & 3 & 2 & 2 & 2 & 2 & 2 & 2 \\ 1 & 2 & 1 & 1 & 1 & 2 & 3 & 2 & 3 & 2 & 2 & 2 & 2 & 3 & 2 \\ & & & & & & & 2 & 3 & 3 & 3 & 4 & 4 & 4 & 4 \\ 2 & 2 & 3 & 3 & 3 & 4 & 4 & 3 & 5 & 5 & 3 & 3 & 3 & 3 & 4 \\ & & & & & & & & & & & & & & \\ 4 & 4 & 3 & 3 & 2 & 4 & 2 & 2 & 1 & 2 & 2 & 2 & & 2 & 2 \\ & & & & & & & & & & & & & & \\ 3 & 3 & 3 & 3 & 3 & 3 & 5 & 3 & 3 & 3 & 2 & 3 & 5 & 4 & 3 \\ 3 & 2 & 2 & 4 & 3 & 4 & 4 & 3 & 4 & 4 & & 5 & 5 & 5 & 5 \\ 3 & 3 & 3 & 3 & 3 & 3 & 2 & 4 & 4 & 4 & 4 & 3 & 3 & 3 & 3 \\ 4 & 4 & 3 & 3 & 4 & 4 & 4 & 3 & 2 & 2 & 2 & 2 & 3 & 3 & 3\end{array}$

HeinOnline -- 111 Yale L.J. 2036 2001-2002

Imaged with the Permission of Yale Law Journal 
Table 7. Coded Data on Fair Trials

\begin{tabular}{|c|c|c|c|c|c|}
\hline Country & 85 & 88 & 91 & 94 & 97 \\
\hline Afghanistan & 4 & 4 & 4 & & \\
\hline Albania & 3 & 3 & 2 & 2 & 2 \\
\hline Algeria & 2 & 1 & 2 & 2 & 3 \\
\hline Angola & 3 & 3 & 3 & 3 & 3 \\
\hline Argentina & 2 & 1 & 2 & 3 & 2 \\
\hline Armenia & & & & 2 & 2 \\
\hline Australia & 1 & 1 & 1 & 1 & 1 \\
\hline Austria & 1 & 1 & 1 & 1 & 1 \\
\hline Azerbaijan & & & & 2 & 3 \\
\hline Bahrain & 2 & 1 & 3 & 2 & 4 \\
\hline Bangladesh & 2 & 4 & 3 & 2 & 3 \\
\hline Belarus & & & & 3 & 3 \\
\hline Belgium & 1 & 1 & 1 & 1 & 1 \\
\hline Benin & 3 & 4 & 1 & 2 & 2 \\
\hline Bhutan & 2 & 2 & 2 & 1 & 3 \\
\hline Bolivia & 2 & 3 & 4 & 3 & 3 \\
\hline Bosnia and Herzegovina & & & & & 2 \\
\hline Botswana & 1 & 1 & 1 & 3 & 1 \\
\hline Brazil & 2 & 1 & 3 & 3 & 3 \\
\hline Bulgaria & 3 & 3 & 1 & 2 & 2 \\
\hline Burkina Faso & 1 & 3 & 4 & 1 & 2 \\
\hline Bunundi & 2 & 2 & 3 & 3 & 3 \\
\hline Cambodia (Kampuchea) & 4 & 3 & 3 & 3 & 3 \\
\hline Cameroon & 2 & 4 & 2 & 2 & 3 \\
\hline Canada & 1 & 1 & 1 & I & 1 \\
\hline Central African Republic & 1 & 2 & 3 & 2 & 2 \\
\hline Chad & 3 & 4 & 2 & 2 & 2 \\
\hline Chile & 2 & 2 & 2 & 2 & 1 \\
\hline China & 4 & 4 & 3 & 4 & 3 \\
\hline Colombia & 3 & 3 & 3 & 3 & 3 \\
\hline Comores & 1 & 1 & 1 & 3 & 1 \\
\hline Congo, Republic of & 3 & 4 & 2 & 2 & 3 \\
\hline Congo, Demncratic Republic of & 4 & 4 & 4 & 3 & 3 \\
\hline Costa Rica & 1 & i & $\mathbf{l}$ & I & 1 \\
\hline Cote D'Ivoire & 1 & 2 & 2 & 3 & 3 \\
\hline Croatia & & & & 2 & 3 \\
\hline Cuba & 3 & 3 & 4 & 3 & 3 \\
\hline Cyprus & 1 & 1 & 1 & 1 & 1 \\
\hline Czechoslovakia & 4 & 3 & 2 & 1 & 1 \\
\hline Denmark & 1 & 1 & 1 & 1 & 1 \\
\hline Djibouti & 2 & 2 & 2 & 2 & 3 \\
\hline Dominican Republic & 2 & 3 & 3 & 3 & 4 \\
\hline Ecuador & 3 & 3 & 4 & 3 & 4 \\
\hline Egypt & 1 & 2 & 1 & 3 & 3 \\
\hline El Salvador & 3 & 3 & 3 & 3 & 4 \\
\hline Equatorial Guinea & 2 & 3 & 4 & 2 & 2 \\
\hline Eritrea & & & & 3 & 2 \\
\hline Estonia & 2 & 2 & 2 & 1 & 1 \\
\hline Ethiopia & 4 & 4 & 2 & 3 & 3 \\
\hline$F i j i$ & 1 & 1 & 1 & 2 & 1 \\
\hline Finland & 1 & 1 & 1 & 1 & 1 \\
\hline France & 1 & 1 & 1 & 1 & 1 \\
\hline Gabon & 2 & 2 & 1 & 3 & 2 \\
\hline Gambia & 1 & 1 & 1 & 3 & 1 \\
\hline Georgia & & & & 3 & 2 \\
\hline Germany, United & & & 1 & 1 & 1 \\
\hline Germany, East & 3 & 3 & & & \\
\hline Germany, West & 1 & 1 & & & \\
\hline Ghana & 2 & 3 & 4 & 1 & 3 \\
\hline Greece & 1 & 2 & $i$ & 2 & 3 \\
\hline Guatemata & 2 & 2 & 2 & 2 & 2 \\
\hline Guinea & 1 & 2 & 2 & 2 & 2 \\
\hline Guinea-Bissau & 2 & 3 & 1 & 3 & 3 \\
\hline Guyana & 1 & $\mathbf{l}$ & 1 & 2 & 3 \\
\hline Haiti & 3 & 3 & 3 & 3 & 3 \\
\hline Honduras & 2 & 3 & 3 & 2 & 4 \\
\hline Hungary & 2 & 2 & 1 & 2 & 1 \\
\hline Iceland & 1 & 1 & 1 & 1 & 1 \\
\hline India & 1 & 2 & 3 & 4 & 3 \\
\hline Indonesia & 3 & 3 & 3 & 3 & 3 \\
\hline Iran & 4 & 3 & 3 & 3 & 3 \\
\hline Iraq & 2 & 2 & 3 & 3 & 3 \\
\hline Ireland & 1 & I & 1 & 1 & 1 \\
\hline
\end{tabular}

HeinOnline -- 111 Yale L.J. 2037 2001-2002

Imaged with the Permission of Yale Law Journal 


\begin{tabular}{|c|c|c|c|c|}
\hline Israel & 1 & 2 & 2 & \\
\hline Italy & 1 & 2 & 2 & \\
\hline Jamaica & 2 & 2 & & \\
\hline Japan & 1 & 1 & & \\
\hline Jordan & 1 & & & \\
\hline Kazakhstan & & & & \\
\hline Kenya & 3 & 3 & & \\
\hline Korea, Republic of & 3 & 4 & & \\
\hline Korea, DPR & 3 & 3 & & \\
\hline Kuwait & 1 & 2 & & \\
\hline Kyrgyzstan & & & & \\
\hline Laos & 4 & 4 & & \\
\hline Latvia & 2 & 2 & i & \\
\hline Lebanon & 3 & 3 & 3 & \\
\hline Lesotho & 1 & 2 & 2 & \\
\hline Liberia & 3 & 2 & & \\
\hline Libya & 4 & 4 & 4 & \\
\hline Lithuania & 2 & 2 & 2 & \\
\hline Luxembourg & 1 & 1 & 1 & \\
\hline Maccdonia & & & & \\
\hline Madagascal & 1 & 1 & 3 & \\
\hline Malawi & 2 & 3 & 4 & \\
\hline Malaysia & 2 & 2 & 3 & \\
\hline Mali & 2 & 2 & 2 & \\
\hline Mauritania & 3 & 2 & 3 & \\
\hline Mauritius & 1 & 1 & 2 & \\
\hline Mexica & 4 & 3 & 2 & 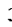 \\
\hline Moldova & & & & \\
\hline Mongolia & & & 2 & 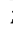 \\
\hline Morocco & 2 & 3 & 3 & 2 \\
\hline Mozambique & 2 & 2 & 4 & 3 \\
\hline Myanmar (Burma) & 3 & 3 & 4 & 3 \\
\hline Namibia & 2 & 2 & 3 & 2 \\
\hline Nepal & 3 & 4 & 2 & 4 \\
\hline Netherlands & 1 & 1 & 1 & 1 \\
\hline New Zealand & 1 & 1 & 1 & 1 \\
\hline Nicaragua & 4 & 3 & 2 & 3 \\
\hline Niger & 3 & 3 & 2 & 3 \\
\hline Nigeria & 2 & 3 & 4 & 4 \\
\hline Norway & 1 & 1 & 1 & i \\
\hline Oman & 2 & 3 & 3 & 3 \\
\hline Pakistan & 3 & 3 & 4 & 4 \\
\hline Panama & 3 & 4 & 3 & 4 \\
\hline Papua-New Guinea & 1 & 1 & 2 & 1 \\
\hline Paraguay & 3 & 4 & 3 & 2 \\
\hline Рега & 2 & 3 & 3 & 3 \\
\hline Philippines & 3 & 2 & 2 & 2 \\
\hline Poland & 2 & 2 & 3 & 1 \\
\hline Portugal & 2 & 1 & 1 & 2 \\
\hline Qatar & 3 & 3 & 3 & 2 \\
\hline Romania & 3 & 3 & 2 & 1 \\
\hline Russia (or former USSR) & 3 & 3 & 3 & 4 \\
\hline Rwanda & 1 & 3 & 3 & 2 \\
\hline Saudi Arabia & 2 & 2 & 4 & 4 \\
\hline Senegal & 1 & 2 & 2 & 3 \\
\hline Sierta Leone & 3 & 3 & 3 & \\
\hline Singapore & 2 & 3 & 4 & 4 \\
\hline Slovak Republic & & & & 1 \\
\hline Sloveria & & & & 1 \\
\hline Somalia & 4 & 4 & & 3 \\
\hline South Africa & 3 & 4 & 3 & 1 \\
\hline Spain & 1 & 1 & 2 & 1 \\
\hline Sri Lanka & 2 & 2 & 2 & 2 \\
\hline Sudan & 1 & 2 & 3 & 2 \\
\hline Swaziland & 2 & 2 & 2 & 1 \\
\hline Sweden & 1 & 1 & 1 & 1 \\
\hline Switzerland & 1 & 1 & 1 & 1 \\
\hline Syria & 3 & 4 & 4 & 4 \\
\hline Tajikistan & & & & 2 \\
\hline Tanzania & 2 & 3 & 3 & 3 \\
\hline Thailand & 3 & 3 & 3 & 2 \\
\hline Togo & 3 & 3 & 2 & 2 \\
\hline Tonga & 1 & 1 & J & 1 \\
\hline Tunisia & 3 & 2 & 3 & 2 \\
\hline Turkey & 2 & 2 & 2 & 2 \\
\hline Turkmenistan & & & & 3 \\
\hline Uganda & 2 & $\mathbf{3}$ & 3 & 4 \\
\hline Ukraine & & & & 3 \\
\hline United Arab Emirates & 2 & 1 & 1 & 3 \\
\hline
\end{tabular}

HeinOnline -- 111 Yale L.J. 2038 2001-2002 


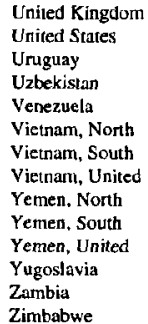

$\begin{array}{lllll}\text { I } & 1 & 1 & 1 & 1 \\ 1 & 1 & 1 & 1 & 3 \\ 3 & 4 & 3 & 3 & 3\end{array}$

Zimbabwe

$\begin{array}{lllll}3 & 4 & 4 & 2 & 3 \\ 2 & 2 & & & \\ 2 & 2 & & & \\ & & 2 & 2 & 3 \\ 2 & 3 & 3 & 3 & 3 \\ 2 & 2 & 2 & 2 & 2 \\ 2 & 2 & 1 & 2 & 2\end{array}$

HeinOnline -- 111 Yale L.J. 2039 2001-2002 


\section{TABLE 8. RELATIONSHIP BETWEEN RATIFICATION OF UNIVERSAL TREATIES AND HUMAN RIGHTS RATINGS, CONTROLLING FOR VARIOUS COUNTRY CHARACTERISTICS}

\begin{tabular}{|c|c|c|c|c|c|c|c|c|c|c|}
\hline$y$ & 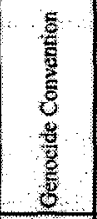 & 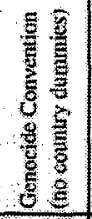 & 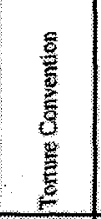 & 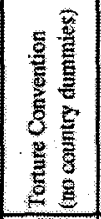 & $\begin{array}{l}\bar{x} \\
\frac{0}{3} \\
4 \\
\end{array}$ & 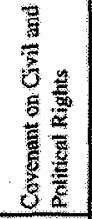 & 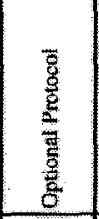 & 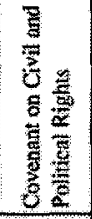 & 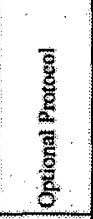 & 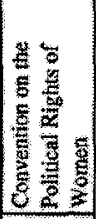 \\
\hline $\begin{array}{l}\text { Hutuan Rights } \\
\text { Measure }\end{array}$ & 6 & $\frac{3}{8}$ & 焉 & $\mathrm{E}$ & E & : & E & 量 & 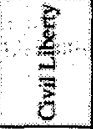 & 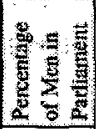 \\
\hline & $\begin{array}{c}0.047 * \\
(0.021)\end{array}$ & $\begin{array}{r}0.0094 \\
(0.0059) \\
\end{array}$ & $\begin{array}{r}0.033 \\
(0.020)\end{array}$ & $\begin{array}{c}0.021^{*} \\
(0.010)\end{array}$ & $\begin{array}{r}0.027 \\
(0.025)\end{array}$ & $\begin{array}{r}0.030 \\
(0.047)\end{array}$ & $\begin{array}{c}-0.002 \\
(0.042)\end{array}$ & & $\begin{array}{r}0.003 \\
(0.008) \\
\end{array}$ & $\begin{array}{c}-0.0004 \\
(0.0003) \\
\end{array}$ \\
\hline $\begin{array}{l}\text { latertational } \\
\text { way }\end{array}$ & $\begin{array}{r}0.063 \\
(0.086)\end{array}$ & $\begin{array}{r}0.207 * * \\
(0.047) \\
\end{array}$ & $\begin{array}{c}0.101 \\
(0.068)\end{array}$ & $\begin{array}{c}-0.002 \\
(0.058)\end{array}$ & $\begin{array}{r}0.097 \\
(0.068)\end{array}$ & $\begin{array}{r}0.072 \\
(0.096)\end{array}$ & & $\begin{array}{r}-0.0059 \\
(0.068) \\
\end{array}$ & & \\
\hline & $\begin{array}{r}0.664 * * \\
(0.082) \\
\end{array}$ & $\begin{array}{r}0.387 * * \\
(0.029) \\
\end{array}$ & $\begin{array}{r}0.128 * * \\
(0.033)\end{array}$ & $\begin{array}{r}0.088 * * \\
(0.018) \\
\end{array}$ & $\begin{array}{r}0.125^{* *} \\
(0.033)\end{array}$ & $\begin{array}{r}0.109 \\
(0.070) \\
\end{array}$ & $\begin{array}{r}0.055 \\
(0.068) \\
\end{array}$ & & & $\begin{array}{r}0.0005 \\
(0.0005) \\
\end{array}$ \\
\hline $\begin{array}{l}\text { Pupu } \\
\text { suze }\end{array}$ & $\begin{array}{r}0.006^{* *} \\
(0.002)\end{array}$ & $\begin{array}{r}-0.0006 \\
(0.0003)\end{array}$ & $\begin{array}{r}-5.0 \mathrm{e}-6 \\
(0.004)\end{array}$ & $\begin{array}{r}0.0007 * * \\
(0.0003) \\
\end{array}$ & \begin{tabular}{|c|}
0.0004 \\
$(0.0036)$ \\
\end{tabular} & $\begin{array}{c}0.005 \\
(0.008)\end{array}$ & $\begin{array}{r}0.005 \\
(0.009) \\
\end{array}$ & & $\begin{array}{c}0.002 \\
(0.002)\end{array}$ & $\begin{array}{l}5.12 e-6 \\
(1.7 e-5) \\
\end{array}$ \\
\hline & $\begin{array}{r}9.08 \\
(8.48)\end{array}$ & $\begin{array}{r}-6.79 \\
(5.05) \\
\end{array}$ & $\begin{array}{r}2.87 \\
(5.48) \\
\end{array}$ & $\begin{array}{r}6.33 \\
(3.31) \\
\end{array}$ & $\begin{array}{r}2.80 \\
(5.49) \\
\end{array}$ & $\begin{array}{l}-4.53 \\
(3.85) \\
\end{array}$ & $\begin{array}{r}-2.70 \\
(4.13) \\
\end{array}$ & & $\begin{array}{l}33 \\
5)\end{array}$ & $\begin{array}{r}-0.052 \\
(0.156) \\
\end{array}$ \\
\hline New regine & $\begin{array}{r}0.096 \\
(0.152) \\
\end{array}$ & $\begin{array}{c}0.291^{* *} \\
(0.112) \\
\end{array}$ & $\begin{array}{c}-0.064 \\
(0.084) \\
\end{array}$ & $\begin{array}{r}-0.024 \\
(0.066) \\
\end{array}$ & $\begin{array}{c}-0.056 \\
(0.082) \\
\end{array}$ & $\begin{array}{c}-0.275 \\
(0.174) \\
\end{array}$ & & & & $\begin{array}{r}0.001 \\
(0.002) \\
\end{array}$ \\
\hline Dea & $\begin{array}{r}-0.031 \\
(0.026)\end{array}$ & $\begin{array}{r}-0.038^{*} \\
(0.018) \\
\end{array}$ & $\begin{array}{r}-0.049 * \\
(0.020) \\
\end{array}$ & $\begin{array}{r}-0.03^{* *} \\
(0.009) \\
\end{array}$ & $\begin{array}{r}-0.048^{*} \\
(0.020) \\
\end{array}$ & $\begin{array}{r}-0.085 * \\
(0.041) \\
\end{array}$ & $\begin{array}{r}-0.096^{*} \\
(0.041) \\
\end{array}$ & $\begin{array}{r}-0.19^{* *} \\
(0.019) \\
\end{array}$ & $\begin{array}{r}-0.19^{* *} \\
(0.019) \\
\end{array}$ & $\begin{array}{r}0.0012^{* *} \\
(0.0004)\end{array}$ \\
\hline & $\begin{array}{r}0.0003 \\
(0.0003)\end{array}$ & $\begin{array}{l}-4 e-5 \\
(2 c-5)\end{array}$ & $\begin{array}{r}-4.6 e-7 \\
(4 e-5)\end{array}$ & $\begin{array}{r}-3 e-5^{* *} \\
(5 e-6) \\
\end{array}$ & $\begin{array}{r}-5.4 e-6 \\
(4 e-5) \\
\end{array}$ & $\begin{array}{r}0.0002 \\
(0.0001)\end{array}$ & & & $\begin{array}{c}-1 \mathrm{e}-6 \\
(1 \mathrm{e}-5)\end{array}$ & $\begin{array}{r}-1 e-6^{* *} \\
(4.3 e-7) \\
\end{array}$ \\
\hline & $\begin{array}{r}-0.011^{*} \\
(0.006)\end{array}$ & $\begin{array}{r}-0.005 \\
(0.003)\end{array}$ & $\begin{array}{r}-0.002 \\
(0.002)\end{array}$ & $\begin{array}{c}-0.001 \\
(0.001)\end{array}$ & $\begin{array}{c}-0.001 \\
(0.002)\end{array}$ & $\begin{array}{c}-0.002 \\
(0.006)\end{array}$ & $\begin{array}{r}-0.0005 \\
(0.0056)\end{array}$ & & & $\begin{array}{r}.00011 \\
(8 e-5)\end{array}$ \\
\hline d $\quad \because \quad \therefore$ & $\begin{array}{r}0.050^{*} \\
(0.022) \\
\end{array}$ & $\begin{array}{c}-0.001 \\
(0.008)\end{array}$ & $\begin{array}{r}0.003 \\
(0.006)\end{array}$ & $\begin{array}{r}-0.006 \\
(0.003) \\
\end{array}$ & $\begin{array}{r}0.003 \\
(0.006) \\
\end{array}$ & $\begin{array}{r}0.003 \\
(0.012) \\
\end{array}$ & $\begin{array}{c}-0.003 \\
(0.011) \\
\end{array}$ & & & $\begin{array}{r}2 c-5 \\
(3 e-5) \\
\end{array}$ \\
\hline GDP growth & $\begin{array}{r}-0.04^{* *} \\
(0.012) \\
\end{array}$ & $\begin{array}{c}-0.015 \\
(0.009) \\
\end{array}$ & $\begin{array}{r}-0.002 \\
(0.006) \\
\end{array}$ & $\begin{array}{r}-0.005 \\
(0.006) \\
\end{array}$ & $\begin{array}{r}-0.002 \\
(0.006) \\
\end{array}$ & $\begin{array}{c}-0.001 \\
(0.012) \\
\end{array}$ & $\begin{array}{l}0.0003 \\
(0.013) \\
\end{array}$ & & & $\begin{array}{r}0.0002 \\
(0.0002) \\
\end{array}$ \\
\hline State fallute & $\begin{array}{r}-0.582 \\
(0.537)\end{array}$ & $\begin{array}{r}0.188 \\
(0.414)\end{array}$ & $\begin{array}{r}0.048 \\
(0.359)\end{array}$ & $\begin{array}{c}-0.178 \\
(0.278) \\
\end{array}$ & $\begin{array}{r}0.066 \\
(0.355) \\
\end{array}$ & $\begin{array}{r}-1.73^{* *} \\
(0.614)\end{array}$ & & & & $\begin{array}{c}-0.011 \\
(0.013)\end{array}$ \\
\hline $\mathrm{Tim}$ & $\begin{array}{r}-0.11 * * \\
(0.021)\end{array}$ & $\begin{array}{r}-0.04 * * \\
(0.008) \\
\end{array}$ & $\begin{array}{r}0.057^{* *} \\
(0.014) \\
\end{array}$ & $\begin{array}{r}0.026^{* *} \\
(0.009) \\
\end{array}$ & $\begin{array}{r}0.054^{* * *} \\
(0.011) \\
\end{array}$ & $\begin{array}{r}0.016 \\
(0.046) \\
\end{array}$ & $\begin{array}{c}0.027 \\
(0.032) \\
\end{array}$ & $\begin{array}{l}0.0033 \\
(0.006) \\
\end{array}$ & $\begin{array}{r}-0.0005 \\
(0.005) \\
\end{array}$ & $\begin{array}{r}-0.0003 \\
(0.0003) \\
\end{array}$ \\
\hline $\begin{array}{l}\text { Lagsed } \\
\text { depend yar. }\end{array}$ & $\begin{array}{r}0.443 * * \\
(0.086) \\
\end{array}$ & $\begin{array}{r}0.746^{* *} \\
(0.081) \\
\end{array}$ & $\begin{array}{r}0.541^{* * *} \\
(0.051)\end{array}$ & $\begin{array}{r}0.936^{* *} \\
(0.044) \\
\end{array}$ & $\begin{array}{r}0.540^{* *} \\
(0.051) \\
\end{array}$ & $\begin{array}{r}-0.133 \\
(0.105) \\
\end{array}$ & $\begin{array}{r}-0.139 \\
(0.105) \\
\end{array}$ & $\begin{array}{r}1.40^{* *} \\
(0.069) \\
\end{array}$ & $\begin{array}{r}1.40 * * \\
(0.069) \\
\end{array}$ & $\begin{array}{r}0.778 * * \\
(0.091) \\
\end{array}$ \\
\hline & & & & & & & & & & $\begin{array}{c}0.209 \\
(0.023) \\
\end{array}$ \\
\hline No. of obs & 628 & 3919 & 1639 & 1639 & 1639 & 373 & 373 & 2739 & 2739 & 3019 \\
\hline Lag-1ketlint & -387.18 & -480.52 & -1492.8 & -1681.6 & -1492.3 & -329.75 & -334.64 & -1996.4 & -1996.7 & \\
\hline Chisquared & 6057.43 & 762.88 & 28840.12 & 893.57 & 24463.74 & & & 1980.40 & 1979.77 & \\
\hline sedado R-s & 0.42 & 0.51 & 0.39 & 0.31 & 0.39 & 0.31 & 0.30 & 0.61 & 0.61 & 0.87 \\
\hline
\end{tabular}

* Statistical significance at $95 \%$ level

** Statistical significance at $99 \%$ level 


\section{TABLE 9. RELATIONSHIP BETWEEN RATIFICATION OF REGIONAL HUMAN RigHTS TREATIES AND HUMAN RIGHTS RATINGS, CONTROLLING FOR VARIOUS COUNTRY CHARACTERISTICS}

\begin{tabular}{|c|c|c|c|c|c|c|c|c|c|c|c|}
\hline ty & 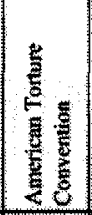 & 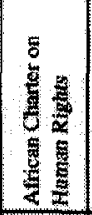 & 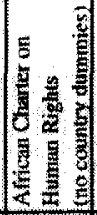 & 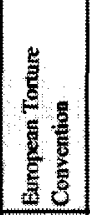 & 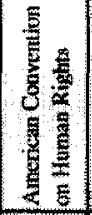 & $\begin{array}{l}5 \\
5 \\
5 \\
5 \\
5 \\
5\end{array}$ & 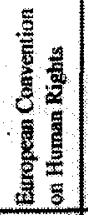 & 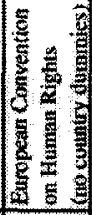 & 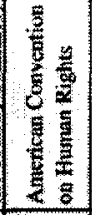 & 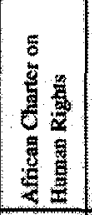 & 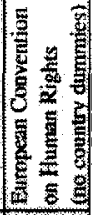 \\
\hline & $\stackrel{5}{E}$ & है & $\stackrel{5}{5}$ & 密 & 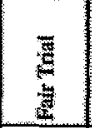 & 㱐 & 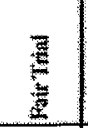 & 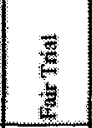 & $\frac{5}{0}$ & $\frac{3}{3}$ & $\frac{\frac{3}{3}}{\frac{2}{3}}$ \\
\hline & $\begin{array}{r}0.313 * * \\
(0.096) \\
\end{array}$ & $\begin{array}{c}-0.007 \\
(0.041) \\
\end{array}$ & $\begin{array}{r}0.030^{*} \\
(0.014)\end{array}$ & $\begin{array}{c}0.285 \\
(0.154) \\
\end{array}$ & $\begin{array}{c}-1.2 * * \\
(0.36)^{2} \\
\end{array}$ & $\begin{array}{c}0.023 \\
(0.114)\end{array}$ & & $\begin{array}{r}0.13^{* *} \\
(0.04)\end{array}$ & $\begin{array}{r}0.17 * * \\
(0.03) \\
\end{array}$ & $\begin{array}{r}-0.05^{*} \\
(0.02)^{4}\end{array}$ & \\
\hline Wnte & $\begin{array}{r}-0.370 \\
(0.727)\end{array}$ & $\begin{array}{r}0.087 \\
(0.107)\end{array}$ & & & & & & & & & $(0.27$ \\
\hline $\begin{array}{l}\text { Civil } \\
\text { wai }\end{array}$ & $\begin{array}{r}0.233^{*}+7 \\
(0.082) \\
\end{array}$ & $\begin{array}{r}0.146^{*} \\
(0.060)\end{array}$ & $\begin{array}{r}0.070^{*} \\
(0.031)\end{array}$ & $\begin{array}{r}-0.072 \\
(0.307) \\
\end{array}$ & $\begin{array}{c}0.134 \\
(0.235) \\
\end{array}$ & $\begin{array}{r}0.053 \\
(0.123) \\
\end{array}$ & & 6) & $\begin{array}{c}0.054 \\
(0.054) \\
\end{array}$ & $\begin{array}{l}70^{* *} \\
046)\end{array}$ & \\
\hline & $\begin{array}{r}0.015 \\
(0.033) \\
\end{array}$ & $\begin{array}{r}0.050 \\
(0.036)\end{array}$ & $\begin{array}{c}0.013^{* * *} \\
(0.004)\end{array}$ & \begin{tabular}{|c|}
-0.187 \\
$(0.117)$ \\
\end{tabular} & $\begin{array}{r}0.006 \\
(0.084) \\
\end{array}$ & & & & $\begin{array}{r}0.049^{* *} \\
(0.013) \\
\end{array}$ & $\begin{array}{r}0.022 \\
(0.016) \\
\end{array}$ & $\begin{array}{c}-0.001 \\
(0.005) \\
\end{array}$ \\
\hline & $\begin{array}{r}34.1 \\
(33.4)\end{array}$ & $\begin{array}{r}-1.14 \\
(4.92)\end{array}$ & $\begin{array}{c}-3.02 \\
(3.79)\end{array}$ & $\begin{array}{c}-1.28 \\
(36.5)\end{array}$ & $\begin{array}{l}123.81 \\
(81.46)\end{array}$ & & & & $\begin{array}{r}-18.6 \\
(21.6) \\
\end{array}$ & $\begin{array}{c}-5.46 \\
(4.19)\end{array}$ & $\begin{array}{r}8.16 \\
(19.37) \\
\end{array}$ \\
\hline New & $\begin{array}{r}0.108 \\
(0.181)\end{array}$ & \begin{tabular}{|c|}
-0.016 \\
$(0.138)$
\end{tabular} & $\begin{array}{r}0.044 \\
(0.116)\end{array}$ & $\begin{array}{r}0.205 \\
(0.382)\end{array}$ & $\begin{array}{r}0.178 \\
(0.579)\end{array}$ & & & $\begin{array}{r}-2.44^{*} \\
(1.10)\end{array}$ & $\begin{array}{c}-0.167 \\
(0.159)\end{array}$ & $\begin{array}{c}0.051 \\
(0.133)\end{array}$ & \\
\hline & $\begin{array}{c}0.017 \\
(0.052) \\
\end{array}$ & $\begin{array}{c}-0.044 \\
(0.031) \\
\end{array}$ & $\begin{array}{r}-0.07 * * \\
(0.02) \\
\end{array}$ & $\begin{array}{c}-0.216 \\
(0.267) \\
\end{array}$ & $\begin{array}{r}-0.46^{* *} \\
(0.15) \\
\end{array}$ & $\begin{array}{r}-0.019 \\
(0.066) \\
\end{array}$ & & $\begin{array}{r}-1.04 * * \\
(0.27) \\
\end{array}$ & $\begin{array}{r}-0.28 * * \\
(0.047) \\
\end{array}$ & $\begin{array}{r}-0.21 * * \\
(0.037) \\
\end{array}$ & $\begin{array}{c}-0.33^{* *} \\
(0.109) \\
\end{array}$ \\
\hline & $\begin{array}{r}3 e-4 \\
(2 e-4)\end{array}$ & $\begin{array}{r}7 e-5 \\
(4 e-4) \\
\end{array}$ & $\begin{array}{r}8 \mathrm{e}-5 \\
(7 e-5)\end{array}$ & $\begin{array}{c}-3 e-4 \\
(1 e-4)\end{array}$ & $\begin{array}{r}8 e-4 \\
(7 e-4)\end{array}$ & $\begin{array}{l}-7 e-5 \\
(0.001)\end{array}$ & & $\begin{array}{r}-2 e-4 * * \\
(6 e-5) \\
\end{array}$ & $\begin{array}{c}-8 e-5 \\
(2 e-4)\end{array}$ & $\begin{array}{r}1 e-4 \\
(1 c-4)\end{array}$ & $\begin{array}{r}-2 e-5 \\
(2 e-5) \\
\end{array}$ \\
\hline & $\begin{array}{r}0.003 \\
(0.006)\end{array}$ & $\begin{array}{l}-3 e-4 \\
(0.004)\end{array}$ & $\begin{array}{c}0.002 \\
(0.002)\end{array}$ & $\begin{array}{c}0.011 \\
(0.014)\end{array}$ & $\begin{array}{r}0.030 \\
(0.022)\end{array}$ & $\begin{array}{c}-0.004 \\
(0.008)\end{array}$ & & $\begin{array}{r}-0.08^{* *} \\
(0.02)\end{array}$ & $\begin{array}{c}-0.001 \\
(0.005)\end{array}$ & $\begin{array}{r}0.006 \\
(0.004)\end{array}$ & $\begin{array}{r}-0.009^{*} \\
(0.004) \\
\end{array}$ \\
\hline & $\begin{array}{r}-0.003 \\
(0.013) \\
\end{array}$ & $\begin{array}{r}9 \mathrm{e}-4 \\
(0.008) \\
\end{array}$ & $\begin{array}{r}0.003 \\
(0.005) \\
\end{array}$ & $\begin{array}{c}-0.319 \\
(0.206) \\
\end{array}$ & $\begin{array}{r}-0.035^{*} \\
(0.017) \\
\end{array}$ & $\begin{array}{r}0.008 \\
(0.016) \\
\end{array}$ & & $\begin{array}{r}0.179 \\
(0.264) \\
\end{array}$ & $\begin{array}{l}-3 e-4 \\
(0.010)\end{array}$ & $\begin{array}{r}-0.007 \\
(0.006) \\
\end{array}$ & $\begin{array}{c}0.317^{* *} \\
(0.097)\end{array}$ \\
\hline $\mathrm{aD}$ & $\begin{array}{l}-0.013 \\
(0.020)\end{array}$ & $\begin{array}{l}-0.008 \\
(0.011)\end{array}$ & $\begin{array}{c}-0.011 \\
(0.010)\end{array}$ & $\begin{array}{r}0.005 \\
(0.026)\end{array}$ & $\begin{array}{r}0.069 \\
(0.040)\end{array}$ & & & & $\begin{array}{c}-0.011 \\
(0.013)\end{array}$ & $\begin{array}{r}-0.009 \\
(0.006) \\
\end{array}$ & $\begin{array}{l}.061 * \\
.025) \\
\end{array}$ \\
\hline 56 & & $\begin{array}{r}0.046 \\
(0.416)\end{array}$ & $\begin{array}{c}-0.041 \\
(0.324)\end{array}$ & & & & & & $\begin{array}{r}0.093 \\
(0.352) \\
\end{array}$ & $\begin{array}{c}0.084 \\
(0.348)\end{array}$ & \\
\hline Tin & $\begin{array}{r}-0.28 * * \\
(0.098)\end{array}$ & $\begin{array}{r}0.038 \\
(0.040)\end{array}$ & $\begin{array}{r}0.007 \\
(0.019)\end{array}$ & $\begin{array}{l}-3 e-4 \\
(0.128)\end{array}$ & $\begin{array}{c}1.20^{* *} \\
(0.365)\end{array}$ & $\begin{array}{c}-0.023 \\
(0.111)\end{array}$ & & $\begin{array}{c}0.121 \\
(0.081)\end{array}$ & \begin{tabular}{|r|}
$-0.11^{* *}$ \\
$(0.036)$ \\
\end{tabular} & $\begin{array}{c}-0.010 \\
(0.011)\end{array}$ & $\begin{array}{c}0.027^{\text {* }} \\
(0.014)\end{array}$ \\
\hline $\begin{array}{l}\text { Lagged } \\
\text { depend }\end{array}$ & \begin{tabular}{|c|}
$0.420^{* * *}$ \\
$(0.127)$
\end{tabular} & \begin{tabular}{|r|}
$0.607 * *$ \\
$(0.078)$
\end{tabular} & \begin{tabular}{|c|}
$0.806^{* *}$ \\
$(0.074)$
\end{tabular} & $\begin{array}{r}0.156 \\
(0.160)\end{array}$ & $\begin{array}{r}-0.83^{* * *} \\
(0.30)\end{array}$ & $\begin{array}{r}-0.209 \\
(0.149)\end{array}$ & $\begin{array}{r}-1.63^{*} \\
(0.82)\end{array}$ & $\begin{array}{c}-0.172 \\
(0.493)\end{array}$ & $\begin{array}{r}1.09 * * \\
(0.146)\end{array}$ & $\begin{array}{r}1.37^{* * *} \\
(0.11)\end{array}$ & \begin{tabular}{|r|}
$2.38^{* *}$ \\
$(0.21)$ \\
\end{tabular} \\
\hline No of obs & 272 & 546 & 546 & 270 & 62 & 166 & 25 & 65 & 505 & 978 & 310 \\
\hline Log Hikelihd. & -246.78 & -544.68 & -582.57 & -176.20 & -38.21 & -152.99 & -12.44 & -24.41 & -351.19 & -727.65 & -119.69 \\
\hline Chl-sgyaared & 303.45 & 431.95 & 227.52 & 233.0.5 & 110.58 & & & 24.18 & 416.24 & 670.91 & 2608.15 \\
\hline Bsendo R-sa & 0.35 & 0.28 & 0.23 & 0.44 & 0.46 & 0.25 & 0.501 & 0.57 & 0.57 & 0.54 & 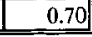 \\
\hline
\end{tabular}

* Statistical significance at $95 \%$ level

** Statistical significance at $99 \%$ level

a The results for the American Convention on Human Rights impact on Fair Trial and the African Charter on Human Rights impact on Civil Liberty become insignificant when the analysis is rerun with only significant variables. 
TABLE 10. RELATIONSHIP BETWEEN RATIFICATION OF HUMAN RightS TREATIES AMONG Fully DEMOCRATIC NATIONS AND HUMAN RightS

\section{RATINGS, CONTROLLING FOR VARIOUS COUNTRY CHARACTERISTICS}

\begin{tabular}{|c|c|c|c|c|c|c|c|c|}
\hline 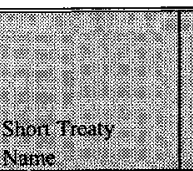 & 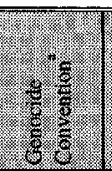 & 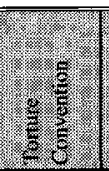 & $\sqrt{\frac{7}{3}}$ & 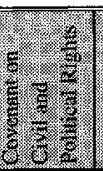 & 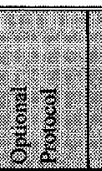 & 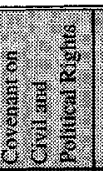 & 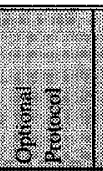 & 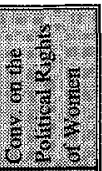 \\
\hline 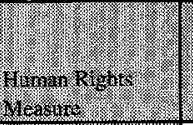 & 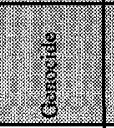 & $\left(\begin{array}{l}\frac{1}{2} \\
\frac{8}{6}\end{array}\right.$ & $\sqrt{\left(-\frac{9}{9}\right.}$ & $\left(\begin{array}{c}-\frac{3}{4} \\
-\frac{3}{4}\end{array}\right.$ & $\left(\frac{8}{8}\right)$ & 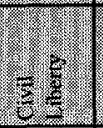 & 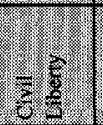 & 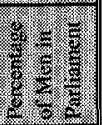 \\
\hline Wingerno by & $\begin{array}{r}-0.056 * * \\
(0.011)\end{array}$ & $\begin{array}{r}0.087^{* * *} \\
(0.033)\end{array}$ & $\begin{array}{l}0.090^{*} \\
(0.046)\end{array}$ & $\begin{array}{r}0.065 \\
(0.056)\end{array}$ & $\begin{array}{r}0.084 \\
(0.061)\end{array}$ & $\begin{array}{r}-0.020 \\
(0.013)\end{array}$ & $\begin{array}{r}-0.038 * \\
(0.015)\end{array}$ & $\begin{array}{r}-0.0004 \\
(0.0002)\end{array}$ \\
\hline 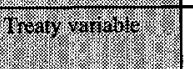 & $\begin{array}{r}0.012 \\
(0.009)\end{array}$ & \begin{tabular}{c|}
-0.025 \\
$(0.021)$
\end{tabular} & \begin{tabular}{r|}
-0.035 \\
$(0.036)$
\end{tabular} & $\begin{array}{c}0.024 \\
(0.048)\end{array}$ & \begin{tabular}{r|}
-0.023 \\
$(0.046)$
\end{tabular} & $\begin{array}{c}-0.002 \\
(0.008)\end{array}$ & $\begin{array}{r}0.011 \\
(0.009)\end{array}$ & -0.0002 \\
\hline 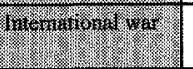 & $\begin{array}{r}0.143^{* * * \times} \\
(0.041)\end{array}$ & $\begin{array}{c}0.101 \\
(0.068) \\
\end{array}$ & $\begin{array}{r}0.103 \\
(0.068) \\
\end{array}$ & $\begin{array}{r}0.066 \\
(0.095) \\
\end{array}$ & $\begin{array}{r}0.072 \\
(0.097)\end{array}$ & $\begin{array}{r}0.003 \\
(0.068) \\
\end{array}$ & $\begin{array}{l}0.0005 \\
(0.068)\end{array}$ & $\begin{array}{r}0.001 \\
0.0006)\end{array}$ \\
\hline 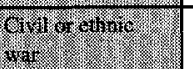 & & $\begin{array}{r}0.130^{* * *} \\
(0.033)\end{array}$ & $\begin{array}{r}0.129^{* *} \\
0.033\end{array}$ & \begin{tabular}{r|}
0.113 \\
$(0.070)$
\end{tabular} & \begin{tabular}{r|}
0.124 \\
$(0.071)$
\end{tabular} & \begin{tabular}{r|}
$0.103^{* *}$ \\
$(0.024)$
\end{tabular} & $\begin{array}{r}0.099 * * \\
(0.024)\end{array}$ & $\begin{array}{r}0.0004 \\
(0.0005)\end{array}$ \\
\hline 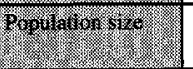 & & $\begin{array}{c}0.001 \\
(0.004)\end{array}$ & $\begin{array}{r}0.0005 \\
(0.0036)\end{array}$ & $\begin{array}{r}0.005 \\
(0.008) \\
\end{array}$ & \begin{tabular}{r|}
0.004 \\
$(0.009)$ \\
\end{tabular} & & .002 & $\begin{array}{l}4 e-8 \\
2 e-5)\end{array}$ \\
\hline Poprotion: & & $\begin{array}{r}2.34 \\
(5.42) \\
\end{array}$ & $\begin{array}{r}2.58 \\
(5,45) \\
\end{array}$ & \begin{tabular}{l|}
-4.67 \\
$(3.85)$ \\
\end{tabular} & \begin{tabular}{l|}
-4.73 \\
$3.86)$ \\
\end{tabular} & \begin{tabular}{l|}
0.233 \\
$(2.82)$
\end{tabular} & $\begin{array}{l}0.221 \\
(2.82) \\
\end{array}$ & \begin{tabular}{c|}
-0.079 \\
$(0.155)$
\end{tabular} \\
\hline 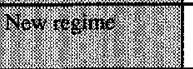 & $\begin{array}{c}0.277^{*} \\
(0.112)\end{array}$ & $\begin{array}{l}-0.039 \\
(0.085)\end{array}$ & $\begin{array}{l}-0.032 \\
(0.083) \\
\end{array}$ & $\begin{array}{l}-0.287 \\
(0.178)\end{array}$ & \begin{tabular}{l|}
-0.294 \\
$(0.179)$
\end{tabular} & $\begin{array}{r}-0.162 \\
(0.073)\end{array}$ & $\begin{array}{r}-0.153^{*} \\
(0.073) \\
\end{array}$ & $\begin{array}{ll}0.001 \\
0.002) \\
\end{array}$ \\
\hline 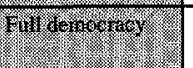 & $\begin{array}{r}0.534 * \\
(0.249)\end{array}$ & $\begin{array}{r}1,089^{* * * *} \\
(0.352)\end{array}$ & $\begin{array}{r}1.182^{* * *} \\
(0.340)\end{array}$ & $\begin{array}{l}-1.95 * \\
(0.884)\end{array}$ & $\begin{array}{c}-1.68^{*} \\
(0.709)\end{array}$ & $\begin{array}{r}0.105 \\
(0.296)\end{array}$ & & \\
\hline 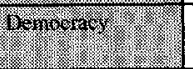 & & $\begin{array}{r}-0.058^{* *} \\
(0.021)\end{array}$ & $\begin{array}{r}-0.061^{* *} \\
(0.021)\end{array}$ & $\begin{array}{c}-0.076 \\
(0.042)\end{array}$ & $\begin{array}{r}-0.073 \\
(0.044)\end{array}$ & $\begin{array}{r}-0.183^{* *} \\
(0.020)\end{array}$ & $\begin{array}{r}-0.185^{* *} \\
(0.020)\end{array}$ & $\begin{array}{l}0.001^{* *} \\
(0.0004)\end{array}$ \\
\hline 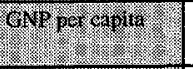 & & $\begin{array}{l}-2 \mathrm{e}-5 \\
(4 \mathrm{e}-5) \\
\end{array}$ & \begin{tabular}{r|}
$-1 e-5$ \\
$(4 c-5)$ \\
\end{tabular} & $\begin{array}{r}2 e-4 \\
(9 e-5) \\
\end{array}$ & $\begin{array}{r}\mathrm{e}-4 \\
(1 \mathrm{e}-4) \\
\end{array}$ & $\begin{array}{r}5 e-6 \\
(1 e-5) \\
\end{array}$ & $\begin{array}{r}3 e-6 \\
(1 e-5) \\
\end{array}$ & $\begin{array}{r}-7.8 \mathrm{e}-7 * \\
(3.8 \mathrm{e}-7) \\
\end{array}$ \\
\hline $\begin{array}{l}\text { Gohri inter: } \\
\text { acpents }\end{array}$ & & $\begin{array}{l}-0.001 \\
(0.002)\end{array}$ & $\begin{array}{c}-0.001 \\
(0.002)\end{array}$ & $\begin{array}{c}-0.003 \\
(0.006)\end{array}$ & $\begin{array}{l}-0.003 \\
(0.006)\end{array}$ & & & $\begin{array}{r}0.0001 \\
(8 \mathrm{e}-5)\end{array}$ \\
\hline 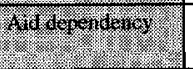 & & $\begin{array}{r}0.002 \\
(0.006)\end{array}$ & $\begin{array}{c}0.002 \\
(0.006) \\
\end{array}$ & $\begin{array}{r}0.003 \\
(0.012) \\
\end{array}$ & & & & $\begin{array}{r}2 e-5 \\
(3 e-5) \\
\end{array}$ \\
\hline Ger grom & & $\begin{array}{r}-0.0018 \\
(0.006)\end{array}$ & \begin{tabular}{r|}
-0.002 \\
$(0.006)$
\end{tabular} & $\begin{array}{l}0.0003 \\
(0.012)\end{array}$ & $\begin{array}{r}0.002 \\
(0.013) \\
\end{array}$ & & & $\begin{array}{c}-0.0002 \\
(0.0002)\end{array}$ \\
\hline Ghat anire & & $\begin{array}{c}0.022 \\
(0.362) \\
\end{array}$ & \begin{tabular}{c|}
0.032 \\
$(0.359)$ \\
\end{tabular} & $\begin{array}{r}-1.72 * * \\
(0.616) \\
\end{array}$ & $\begin{array}{r}-1.72 * * * \\
(0.613) \\
\end{array}$ & \begin{tabular}{r|}
0.088 \\
$(0.268)$ \\
\end{tabular} & $\begin{array}{c}0.088 \\
0.269) \\
\end{array}$ & $\begin{array}{c}-0.011 \\
(0.013) \\
\end{array}$ \\
\hline Mrit & $\begin{array}{l}-0.007 \\
(0.008)\end{array}$ & $\begin{array}{r}0.061^{* *} \\
(0.014)\end{array}$ & $\begin{array}{r}0.058^{* *} \\
(0.011)\end{array}$ & \begin{tabular}{r|}
0.019 \\
$(0.046)$ \\
\end{tabular} & $\begin{array}{r}0.043 \\
(0.033) \\
\end{array}$ & $\begin{array}{r}0.004 \\
(0.005) \\
\end{array}$ & $\begin{array}{l}-0.001 \\
(0.004)\end{array}$ & $\begin{array}{r}-0.0003 \\
(0.0003) \\
\end{array}$ \\
\hline 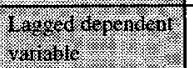 & & \begin{tabular}{r|}
$0.525^{\text {**** }}$ \\
$(0.051)$
\end{tabular} & \begin{tabular}{r|}
$0.529^{*} *$ \\
$(0.051)$
\end{tabular} & \begin{tabular}{l|}
-0.146 \\
$(0.106)$
\end{tabular} & $\begin{array}{l}-0.147 \\
(0.106)\end{array}$ & $\begin{array}{c}1.39^{* * *} \\
(0.069)\end{array}$ & \begin{tabular}{r|}
$1.39 * * *$ \\
$(0.069)$
\end{tabular} & $\begin{array}{r}0.774 * * \\
(0.092)\end{array}$ \\
\hline Conitants: & & & & & & & & $\begin{array}{ll}0.212 \\
(0.086) \\
\end{array}$ \\
\hline Wo. or obs. & 927 & 1597 & 1597 & 373 & 373 & 2739 & 2739 & 019 \\
\hline 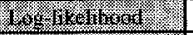 & -912.76 & -1483.01 & -1484.37 & -328.76 & -328.73 & -1994.07 & -1991.65 & \\
\hline Ch-grand & 353.55 & 1800.23 & 1814.69 & & & 1990.71 & 1979.21 & \\
\hline $82+100 \mathrm{~N}$ - & 0.12 & 0.38 & 0.38 & 0.31 & 31 & 0.61 & 0.61 & \\
\hline
\end{tabular}

* Statistical significance at $95 \%$ level

** Statistical significance at $99 \%$ level

a Genocide Convention results include countries with democracy ratings from 8 to 10 . 